\title{
Studies on the Production and Utilization of Natural Food in Indonesian Carp Ponds ${ }^{1}$ )
}

\author{
K. F. VAaS \& A. VAas - VAN OVEN \\ Laboratory of Inland Fisheries, Bogor, Indonesia.
}

INTRODUCTION

The principal difference between Indonesian and European fish ponds is the fact that in the first case hardly any fodder is introduced and the fish subsist on natural food, the natural biota of the pond, sometimes encouraged by the introduction of sewage, kitchen waste, bran and green manure. Although some of these extraneous substances will be eaten directly by the fish, and notably by the common carp, natural food will always be the principal source of food.

It was the aim of our work to study the development of organisms serving as natural food for the common carp (Cyprinus carpio L.) in such ponds, their interrelationships, the influence of the carp on their quantitative and qualitative development and the utilization of those organisms by the fish.

The work carried out will be related in four sections.

In the first section a description will be given of the guts contents of 500 carp growing in a pond of the hatchery of the Laboratory of Inland Fisheries at Bogor, Java, from the moment the mouth and anus were formed until a total length of $135 \mathrm{~mm}$ was reached.

Owing to the large number of samples to be studied in the first section, supply of natural food could not be studied simultaneously. This was done in the experiments to be related in the second section, where the guts contents of the carp were studied together with the development of natural food during 4 growing periods. In compara-

1) Published by permission of the Head of the Laboratory of Inland Fisheries. The material of this article was circulated in mimeo-ed form in Indonesian for interdepartemental use by the Laboratory. Part of the material was presented at the 7th Meeting of the I.P.F.C. in Bandung in 1957, and will be published in abstract form in the Proceedings. 
ble, unstocked ponds the development of biota was studied simultaneously in order to elucidate the influence of the fish.

In order to compare our Bogor findings with conditions in other ponds, 2 ponds at Sukabumi, Java, and 4 ponds at Palembang. Sumatra, were studied. The guts contents of the fish were compared with the supply of natural food in each case. These findings are given in the third section.

Finally an analysis is given of a sewage pond at Bodjong Loa, near Bandung City, where food supply and consequently food utilization by the carp proved to be totally different.

\section{ACKNOWLEDGEMENT}

It is a pleasure to acknowledge our indebtitude to the following persons who gave us their help, advise or encouragement throughout the work in the field or in the laboratory: H. SAANIN, Head and Nelly Harahap, Suherman, Much. Machfud, A. Rachman, Staff of the Laboratory of Inland Fisheries, Gelar Wiraatmadja, (Sukabumi), Head and Staff of the Inland Fisheries Extension Service of Bandung Area, Dr. H. H. F. Hamann, Bogor, Sozhardi, Depok and Hadji Kosasin, owner of the pond at Bodjong Loa, Bandung.

\section{SURVEY OF THE LITERATURE}

Common carp has been cultivated in ponds in Central Europe for centuries and an extensive literature exists on its natural food in those ponds. In America this fish invaded many open waters and its feeding habits were related in a few recent papers.

The recent intensive carp culture in Israel also contributed to our knowledge on the subject. Although in Indonesia a good deal of experience with carp culture has been gathered, published records of investigations concerning its food in ponds are restricted to a brief statement by BuschKIEL (1938), to the effect that, under experimental conditions, carp fry consumed Crustaceae 3 days after hatching, Tubificidae 6 days, and Chrironomidae after 7-9 days. The older European literature has been summarized many times and need not be repeated here. The picture, as obtained from a study of the works of WUNDER $(1936,1949)$ on the food of the German cultivated carp, of MOEN (1953) on the free-living American carp, of KLusT (1940), VONK (1941) and JANCARIK (1956) on the functional anatomy and physiology of the digestive system and of many other papers, is about as follows:

After hatching the fry begin to take in food at an early stage. 
According to various authors (Kostomarov 1941, AlikunhI) 1951, Mitra \& Mohapatra ${ }^{1}$ ) 1956), animal food gives far better growth than vegetable food. After feeding on plankton in the first stages the fry quickly turn to littoral fauna and afterwards to bottom fauna, taking in worms and larvae of aquatic insects together with vegetable food such as seeds, thread algae and vegetable detritus. However, contrary to what was held earlier by many other German authors, crustaceans are still important, as was specially emphasized by WUNDER.

All evidence goes to show that the common carp is able to use widely different kinds of natural food according to their relative availability and wide differences are often observed between the contents of the guts of entirely comparable carps grown up together in the same pond. Under special circumstances mass occurrence of a certain organism combined with the absence of others, the guts contents of carp may become quite unusual. In the sewers of Strassburg, for instance, the guts were crammed with Vorticella.

Other fishes and fry are sometimes eaten and Kostomarov \& HRABÉ (1943) succeeded in inducing cannibalism in overstocked ponds, beginning when the fish measured $12.8 \mathrm{~cm}$. in length. The term "typical bottom-feeder", used for the common carp in older European literature, is not appropriate according to WUNDER, although bottom fauna and notably midge-larvae, are nearly always present and important.

According to WUNDER, MOEN and others, vegetable food is of secondary importance only, for all stages in the life of the common carp.

In order to be of importance as food for the carp a certain organism must occur in sufficient quantity and be obtainable and digestable. Many controversies between older European authors about the relative importance of Crustaceae and Chironomidae find their origin in differences between the availability of the organisms. Differences in size and fertility of the ponds and in climate often cause drastic changes in the biota of the pond available as food for the carp. However, to the sampling investigator availability is not similar to availability to the grazing carp.

WUNDER $(1927,1932)$ studied the question how the carp finds its food. By experiments in which carp were blinded and the sense of smell made ineffective, WUNDER found that sight and smell were comparatively unimportant and that even the sense of taste was not the principal means by which the carp selects it food, but rather the

1) The work of the Indian authors was carried out with the related Indian carps Catla, Labeo and Cirrhina. 
sense of touch. Water is pumped into the mouth by the branchial apparatus and by the movements of the mouth, and organisms ingested are tested as to their palatability by the organs of taste and touch in the mouth and on the lips and barbels. Taking in a mouthful the fish extracts the nutriment and spits out the undesired residue. The intricate mechanism of the buccal apparatus enabling the carp to open its mouth was described by van DoBBEn (1937). Two different mechanisms were distinguished. By means of the first the mouth is opened widely and protuded along the longitudinal axis of the body, by means of the second mechanism the mouth is opened and pointed downwards. In this position the mouth is only partly opened and the caudal pair of barbels are pushed downwards. Thus they are in a favourable position to act as sense-organism for checking the food on the bottom. However, taking food from the bottom is not the only way of feeding. Drowned aerial and terrestrial insects, such as ants, are very often ingested and must be picked up from the surface.

Dividing the feeding activity of the fish into three stages WUNDER distinguishes a) alerting - the process by which the fish notices its food from afar, b) stalking - the process of approaching its prey and snapping it up, and c) the final checking of the food as to its suitability, when already grasped. He found that the eyes of the carp are of some importance in the first two stages. The enormous numbers of Crustaceae often found in the guts prove that a good deal of food is taken from the water and not from the bottom. Many authors found that plankton showed a different specific composition inside the guts than in the open water from which it had been collected. According to WUNDER this fact need not imply a process of specific selection by the fish. Very often Crustaceae occur in definite swarms, concentrated owing to phototropism or other factors. Once having noticed such a swarm the carp continues feeding on it. It should not be forgotten that the eye of the fish, although not adapted to see at long distances, acts as a hand-lens within very short distances. In such cases as when WUNDER found 100,000 Daphnia's in the guts of a large carp, it is impossible to assume ingestion by means of a simple straining action, or to assume that the carp picked the Daphnia's up individually, if they had been distributed evenly throughout the water. However, observing a carp feeding on a dense swarm of Crustaceae it is evident that by straining only a fairly large number can be ingested. Before the food passes into the gullet the molar-like pharyngeal teeth on the fifth branchial arch come into play, crushing the food against the horny plate attached to the ventral process of the basioccipital bone. In European carp these teeth are strong enough for mastication when the fry measure $1.2 \mathrm{~cm}$. 
With this apparatus the carp is able to crush the cases of Trichoptera larvae etc., spitting them out after ingesting the larvae. The action was studied in detail by KLUST (1.c.).

From the mouth the food passes on into the gullet and the intestine. In all Cyprinidae a proper stomach is absent as well as the pyloric caeca (appendices pyloricae), found in many other fishes. The ductus choledochus from the gall bladder has its aperture closely behind the oesophagus and, anatomically, this point always indicates the end of the stomach. Nowhere in the intestinal tract can cells producing pepsine or hydrochloric acid be found, which fact adds further proof for the complete absence of a stomach. Form and development of the guts of German carp were studied by KLuST (l.c.). There are no salivary glands in the mouth of the carp and in the intestine the glands described by LIEBERKÜHN for the mammalian guts are absent. There is a large liver and a gall bladder. The opening of the pancreas is next to that of the gall bladder on the upper right side of the intestine. As in many other fishes - notably in those without appendices phyloricae - the pancreas does not show as an individual gland, but can be traced as a diffuse organ divided into many branches along the intestine and various blood vessels, also penetrating the liver. Still it is possible to separate both tissues, as no true amalgamation does occur. (Vonk 1.c.).

Digestive enymes of the common carp were studied by VonK with modern methods. In this paper the older literature is summarized. VoNk found a total absence of pepsine, but presence of: trypsine, erepsine, amylase and maltase.

Invertase, found in the closely related Carassius auratus L. by SARBAHI (1951), was absent in the carp. Those enzymes were found to be closely related to those of higher vertebrates. Besides being active in the usual way of emulsifying fats, the gall contains some amylase. The main production centre of amylase was found to be located in the pancreas. The enzyme is very active and has its optimal $\mathrm{pH}$ at 6.25 . The pancreas produces inactive trypsine, to be activated by the enterokinase from the guts. The protein digestion is completed by erepsine, originating in the guts and practically absent in the pancreas. The optimal activity of both is found in an environment of $\mathrm{pH}$ 8-9. In the intestine of the living fish Vonk found a $\mathrm{pH}$ between 6.73 and 7.71. Later authors confirmed most of Vonk's findings. Lipase activity was found in the guts and in the liver and pancreas (JANCARIK 1.c.). BONDI \& SPANDORF (1951) showed that cellulose is digested by the live carp to an appreciable degree. However, no enzymes digesting cellulose or hemicellulose could be demonstrated in extracts from pancreas and intestine. Neither could any chitinase-activity be demonstrated. 
The authors offer the possibility of an action of the bacterial flora in the intestine as a theoretical explanation although the presence of such a flora is contested by others (SNIESzko 1957). They succeeded in demonstrating digestion of bran in vitro by extractions of the pancreas. This is an interesting finding, as bran is so often used in Indonesian carp ponds. KLUST reported that amylase and lipase of small fry was less active than that of adult fish.

During World War I, German physiologists such as KNAUTHE, ZUNZ and CRONHEIM, endeavouring to account for the erratic results obtained by German carp growers with fodder, formulated an interesting theory. Starting from the assumption that the secretions of pancreas and guts would be insufficient to break down vegetable food, they thought that the enzymes of the Crustaceae, Oligochaetae and Chironomidae, taken in as food, cooperated with those of the carp.

These animals themselves subsist on vegetable matter and their digestive tract contains enzymes in large quantities. In the opinion of the authors mentioned the importance of natural food for the carp must be sought in the better digestion caused by the action of these exogenic enzymes.

At that time the enzymes of the carp were insufficientily understood and it was thought that carp could not subsist on artificial food alone.

After the laboratory experiments of SEILER (1938) this opinion cannot be upheld. Her experiments clearly show that carp can thrive on artificial food alone - in some cases even better than on natural food-provided the food shows the correct ratio between nitrogen and carbon in its chemical composition. The evident importance of natural food for ponds where artificial feeding is intensively practized, is thought to be a supply of vitamines (see. e.g. YASHOW 1954, TAL 1956).

SCHÄPERCLAUS (1953) accepted the above hypothesis only in case of the enzymes derived from Chironomidae and not for those from Crustaceae, because he thought that the peptic ferments of those animals would cease their activity forthwith in an alkaline environment. KLUST (1.c.) feeding carp alternately on potatoes and on potatoes with live Daphnia's did not find an increase in the percentage of starch grains broken down. However, SchlotTkE (1938) found that after feeding on worms a more active extract could be prepared from the guts of carp than after a diet of fishmeal and sugar. JANCARIK (1.c.) studied extracts from worms, Crustaceae and Chironomidae. He found all of them-therefore, contrary to the opinion of SCHÄPERCLAus, the Crustaceae too - to be active at a $\mathrm{pH}$ of 8.1. A mixture of such extractions with enzymes from the carp showed considerable increase in digestive activity and this author is therefore of the opi- 
nion that exogenic enzymes are most important for digestion in the intestine of the carp. The activating influence of such enzymes is not restricted to the digestive enzymes of the organisms ingested, but autolytic enzymes also come into play.

Summarizing all available evidence pertaining to our problem we arrive at the following picture:

The common carp, feeding mainly on natural food will be fully able to digest proteins and carbohydrates including cellulose, but excluding chitine.

External chitinous sceletons will be crushed by the pharyngeal teeth so as to make the inside of the organisms accessible to the action of the digestive enzymes.

The velocity of the process of digestion - the time the food stays inside the guts - is accelerated by increased temperature more or less in accordance with VAN 'T HoFF's law. (VON MALTZAN 1935, KARSINKIN 1935). The rate of filling affects the speed of digestion in the guts even stronger than temperature. (KLUST l.c.). When the guts are filled to capacity the food remains inside for a short time, but when the guts are sparingly filled it remains much longer.

Moreover when the guts are crammed with food the enzymes do not properly reach the food. Similar phenomena are found in many other animals and are caused by the peristaltic movements of the guts, studied in the common carp by von MALTZAN (1.c.), who found great similarity with other vertebrates. KLust (l.c.) studied the time natural food stayed in the guts of German common carp at a temperature of $17^{\circ}$. In accordance with older workers he found periods of 4-5 hours, which means that the carp completely fills its guts $4-5$ times a day, provided that feeding does not stop during certain hours. KLUST did not find any evidence of a definite "siesta", contrary to WUNDER (1936), who observed carp in Silesia resting without taking any food from $5-7$ p.m.

Many authors have studied the efficiency of digestion in fish, either in vitro or with the living animal, using chemical substances or the organisms themselves. (Karsinkin 1.c. MANN 1935, KLUST 1.c.).

Their findings can be summarized as follows:

The efficiency of digestion is unaffected by changes in temperature. Oligochaetae are easily digested, prongs and patches of the empty skin being the only remains. Cladocera are easily digested, parts of the skins, legs, brood-cases with eggs and guts, are found in the faeces. Probably the eggs are still viable after leaving the anus. Cyclopidae are often even better utilized than Cladocera. Ephemeroptera larvae and other insect larvae are rather easily digested, parts of the chitinous skeleton and of the legs forming the only remains. Chironomidae are less easily digested, the less so the older and larger they are. 
The tough chitinous skin resists penetration by enzymes. Some could be ,revived" after a period of 3 hours in the guts.

Many authors agree that single-celled algae are either partly digested or not at all. (WIRSZUbSKY 1948, 1953, Alikunhi 1.c.). Already in 1928 , Langhans \& Pollak were able to cultivate Chlorella and Scenedesmus from faeces of the common carp, thus proving that many cells were not digested. The present authors did the same in Bogor.

As our experiments do not deal with the utilization of fodder supplied from outside, the extensive literature on this subject will not be discussed here.

SECTION 1.

GUTS CONTENTS OF THE COMMON CARP, GROWING IN A POND OF THE HATCHERY AT BOGOR, FROM THE MOMENT THE MOUTH AND ANUS ARE FORMED UNTIL A TOTAL LENGTH OF 135 MM IS REACHED.

\section{MATERIAL AND METHODS}

On January 29th 1956 some mature carps were spawned with the result that about 150 gram of eggs adhered to the fibers of the ,kakaban"1). Transfered to an ordinary pond of the hatchery, these eggs developed into about 25,000 larvae of about $5 \mathrm{~mm}$ in length, without functional intestinal tract, mouth or anus and with a well developed yolk sac. On Febr. $2 n d$. the swim bladder was filled, the yolk sac was partly absorbed, and intestinal tract-measuring $130 \mu$ in its widest part-was formed. The animals, having filled the swim bladder with air, were able to swim and chase their own food. The first sample was taken that day.

The pond measured $205 \mathrm{~m}^{2}$ and received the rather limedeficient water of the Bogor hatchery having a neutral reaction, but it was fertilized by adding $50 \mathrm{~kg}$ of stable manure and $50 \mathrm{~kg}$ green manure every week. The fish were given a small dose of rice bran each day, after the regular sampling was completed in the early morning. No bran was found in the guts, it being completely digested within 24 hours, so that feeding did not interfere with our purpose of testing the intake of natural food during growth from the hatching until the consumption stage.

As the fish increased in size, the stock had to be thinned out, so as to ensure good growth. This was done as shown in table I.

1) Indonesian name for the fiber-mattings used in spawning the common carp. 
TABLE I

Size and number of the fish during the experiment.

\begin{tabular}{cccc}
\hline Period & Date & Number & Initial size in mm. \\
\cline { 2 - 4 } I & $2 / 2$ & 25000 & $7-8$ \\
II & $23 / 2$ & 5000 & 18 \\
III & $23 / 2$ & 2000 & 39 \\
IV & $26 / 4$ & 1065 & 50 \\
V & $27 / 6$ & 200 & 75 \\
cropped & $13 / 8$ & 134 & 136
\end{tabular}

During the last two periods resp. 10 and 4 large mudjairs (Tilapia mossambica $P$.) were stocked together with the carp in order to suppress a too extensive growth of Spirogyra.

During the last month the carp were sexually mature.

Regular sampling was carried out: from $2 / 2$ until $31 / 3$ every other day, from $31 / 3$ until $25 / 5$ every fifth day and from $25 / 5$ until the end every tenth day.

Each sample consisted of 10 fish, gathered with nets and immediately preserved in formaline. In total 50 times 10 fish were examined. Each time the crop was thinned out a new supply of water was given to the pond, during the experiment a steady, slow supply of water was maintained.

Not earlier than one day and not later than five days after sampling the fish were cut open and the entire intestinal tract was removed. The contents were pressed out and the guts cut open to remove all contents. In the case of very small fry the contents could be counted under the microscope, but in the case of larger amounts aliquot samples had to be counted. For this purpose all contents were washed into stoppered funnels and allowed to settle during 24 hours. The following day the quantity was measured with the aid of a calibration previously fixed on to the stems of the funnels. A fraction of the contents was then studied microscopically and care was taken that this fraction was never less than about $1 / 6$ of the total amount. In most cases this quantity amounted to $1 / 3$ or more. The remainder was allowed to settle another day and measured on the third day. In this way a multiplication factor was established and the numbers counted could be related to the numbers present in the whole sample. Towards the end of the experiment several guts had to be cut into sections and more than one funnel had to be used for one fish. Allways all data of the 10 carp forming the sample were combined and treated as a unity. This was done because often differences were found between entirely comparable carps growing together in the same pond and also sampled together. By taking 10 fish together each time we tried to minimize the effect of those differences. In the 
third Section some examples of individual differences will be shown. Each organism encountered was identified as far as possible. In the intestine the food is present in a crushed, broken and cut condition. Still it is possible to identify most organisms from their remains. The heads of the Chironomidae, their guts still filled with detritus, the tracheae of the pupae, the empty, wrinkled skins with rows of chaetae of the Oligochaetae and the shells, and eggs of the Crustaceae, all make these organisms conspicuous. As was stated earlier, some organisms are not digested. These were not listed. Serious difficulties are encountered in the numeration of many organisms and nearly all authors mentioned above have commented on this subject. Thread algae and vegetable remains are often partly digested, which fact has to be taken into account when ultimately their nutritive importance has to be evaluated.

The carp always has a good deal of mud and detritus in its guts, picked up from the bottom of the pond. For this reason single chaetae of Oligochaetae and fragments of the shell of snails do not prove that the live organisms were ingested. If, however, empty skins with rows of chaetae are found, together with operculae and radulae of snails it becomes highly probable that these organisms have served as food.

After counting and listing all identifiable remains found, during which process the rate of digestion was taken into account, all numbers were converted into volumes, with the aid of special standards established previously as the result of repeated measurements. It follows from what was stated above that the figures obtained must be considered to be estimates. It is doubtful whether exact figures can be obtained in the case of a fish ingesting detritus and mud as does the carp (HyNes, 1950). It is hoped that the large number of samples studied by our method will counteract the relatively arbitary standards of our final evaluation.

Upon studying methods for the examination of intestinal contents, as critically summarized by Hynes (1.c.) and Pillay (1952), we have chosen the procedure described below. All food was divided into groups. First it was established how many times each group was found in the guts. In the second place it was established how many times each group formed the main part of the contents by volume and sometimes also how many times it ranked second place. Finally the total volume was given in the form of tables and in some tables it was computed into a percentage of the total contents. In this way the importance of each group could ultimately be judged by three separate standards. 
As was stated above, conclusions about feeding were based on the evidence offered by 500 analyses of guts contents. As it is impossible to relate all data here, only summaries and illustrative examples will be given.

As regards their importance as food for the carp, all biota can be divided theoretically into the following groups:

1. Organisms living in the pond, but not ingested by the carp. In this respect it should be noted that certain organisms are ingested in the later stages and not in the earlier, as the fish is then too small.

2. Organisms ingested, but only partly digested or not at all. Some organisms are poorly digested when occuring in small numbers in the guts, but distinctly better utilized when present in bulk.

3. Organisms ingested and digested but, owing to the small numbers present, not of any quantitative importance as a source of food.

4. Organisms present, fully digested and occuring in sufficient quantities to form an important item of the diet.

It should be added that the carp does also ingest other food besides living or decaying organisms namely, vegetable detritus, either from autochthonous or from allochthonous origin. Among the organisms of the first group we found in our pond: Tadpoles and adult frogs small fishes such as Lebistes and Puntius binotatus, Crabs and large aquatic insects, together with the later and larger stages of their larvae, such as Sphaerodema, Notonectidae, Velidae, Cybister and Gyrinus, which insects themselves prey upon the small carp fry. A description of the biota in the pond will be given in the second Section. Several single-celled, small green algae belong to the group that was ingested but not at all or not fully digested. They were found throughout the guts with quite green chromatophores and often so viable that sterile media, inoculated with faecal matter taken from the anus by means of sterile capillaries, showed a marked growth after a short time. Scenedesmus, Eudorina and Pandorina could be grown in this way. Desmids - Cosmarium, Euastrum, Staurastrum etc. were usually partly digested, the large cells of Closterium usually far better. Euglena, often occuring in the pond in bulk, was some times ingested by the very small fry and partly utilized.

Filamentous blue-green algae, such as Oscillatoria and Lyngbya were poorly digested and the same was found for Spirogyra. However, this alga often occurs in bulk and may be taken by the fish in partly decaying condition. In that case the carp will derive a certain amount of food from this source. Whether a fully digestable 
organism will be of quantitative importance or not, obviously depends on its occurrence in the pond, but also on the dimensions of the fish.

According to our findings the food of the carp and carp fry in our pond, can be divided into 9 groups as follows:

1. Chironomidae. Besides larvae and pupae belonging to the Subfamily of Tanypodinae and Chironominae, Sectio Chironomiriae and Sectio Tanytarsiae, we wish to include in this group the Ceratopogonidae of the Bezzia-type. As the livespan of the larvae is so much longer than that of the pupae, the latter were but sparingly represented.

2. Other Insects. Mainly larvae of other aquatic insects, such as Ephemeridae, Odonata and Coleoptera. Terrestrial insects, such as ants, accidentally fallen into the water, are often eaten.

3. Crustaceae. Although in our original files those animals are divided into Cladocera, Cyclopidae and Ostracoda (Cypris spp.) they are jointly mentioned in the summaries given in the present paper. Frequent genera were Macrothrix spinosa KING (adult females and juveniles, adult males few), Diaphanosoma spec., Ilocryptus longiremis SARS and Mesocyclops spec. These Crustaceae were kindly identified by DR. H. H. F. HamanN, Bogor, who took up the study of these organisms in ponds and their remains in the guts of the carp at our request and to whom our indebtitude is due.

4. Oligochaetae of the genera: Dero, Limnodrilus, Nais and sometimes Branchiura Sowerbyi BEDD., were often encountered. As pointed out by KLUST (1935) it is very difficult to establish the exact number of these worms in the guts, owing to their delicate structure and the very high digestibility.

5. Gastropoda. Many crushed shells (Limnaea) and also some radulae and opercula of such snails as Melania and Vivipara (Paludina) were found. These animals are most frequent in the pond. Their total number can only be estimated as entire shells are rare. The body itself does not leave any recognizable traces after digestion.

6. Closterium. This large-celled Desmid often occurs in bulk in the water and may be taken in appreciable numbers, mainly by the very small fry. Not all cells are completely digested.

7. Rotatoria and their eggs are an important item for tiny fry. The cells are completely digested, but only of quantitative importance when taken in bulk.

8. Protococcales, Flagellatae and Protozoa are grouped together. They are important only for the very small fry, as will be seen from the tables, and completely without value at the later stages. In addition to the organisms mentioned earlier we wish to cite: Phacus and Arcella. 


\begin{tabular}{|c|c|c|c|c|c|c|c|c|c|c|}
\hline 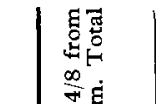 & 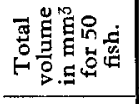 & 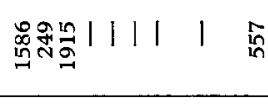 & & & & in & 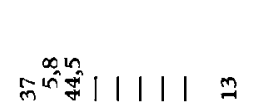 & & & \\
\hline 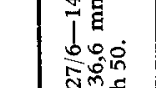 & 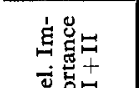 & 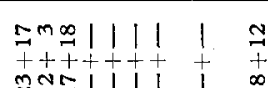 & in & & 息 & + & 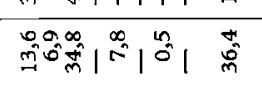 & & & \\
\hline 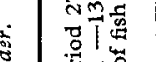 & 覀蓜 & $\boldsymbol{n}^{N}=|||| 1 \mid$ & in & & 岁 & m & 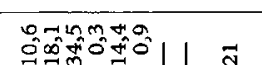 & 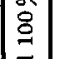 & & \\
\hline 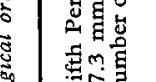 & 矛察: & 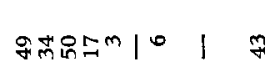 & & & 菢 & a & 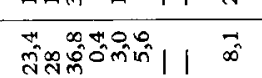 & tig & & \\
\hline & 焉 & & & & $a$ & & 然 & & & \\
\hline & 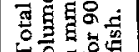 & $\mathbb{N}_{\exists=}^{n}|\vec{m}|^{\infty} \mid$ & & & & & 001 & & & \\
\hline 108 & Ho.s. & & & & & in & 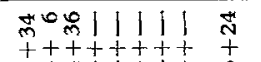 & & & \\
\hline 或要 & 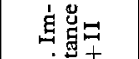 & mㅛ민 & 8 & & & & 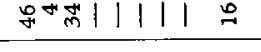 & & & \\
\hline 题最莒 & वे & Nmoj|cil in & \& & 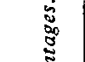 & & & $\hat{m}_{m}^{m} \tilde{n}|\stackrel{\infty}{\sim}| \vec{n} \mid \vec{N}$ & & & \\
\hline 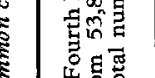 & 密 & న్లో & & $\begin{array}{c}\bar{\Sigma} \\
\vdots \\
\vdots \\
\Sigma \\
\Sigma\end{array}$ & $\stackrel{+}{ \pm}$ & T & 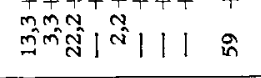 & & & \\
\hline & 造客 & & & $\begin{array}{c}8 \\
8 \\
8\end{array}$ & 迳 & & 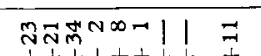 & & & \\
\hline : & 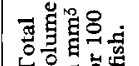 & 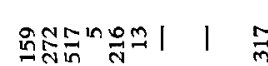 & & 总 & 总 & $m$ & $111 \quad \begin{array}{l}4 \\
1+\pi\end{array}$ & & & \\
\hline 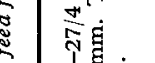 & $\frac{1}{10.50}$ & $m=ー+N \infty-1 \mid$ & 0 & ב & 落 & & 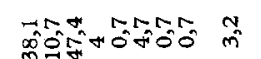 & & & \\
\hline 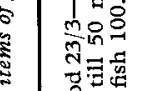 & 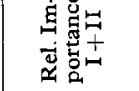 & 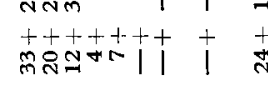 & $\frac{1}{9}$ & $\begin{array}{l}3 \\
3 \\
3 \\
3\end{array}$ & 营 & $n$ & 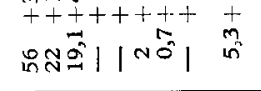 & $\begin{array}{l}\circ \circ \\
\vdots \\
\vdots\end{array}$ & & \\
\hline 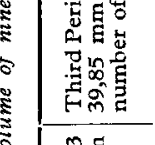 & 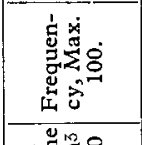 & 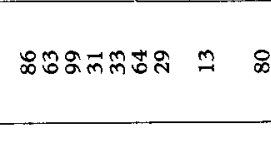 & & 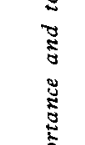 & & -1 & 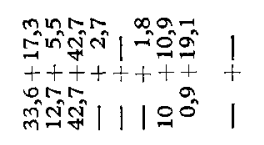 & 哥 & & \\
\hline 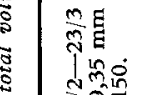 & 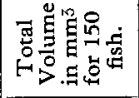 & 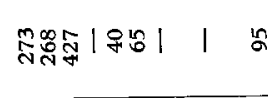 & & है & & in & 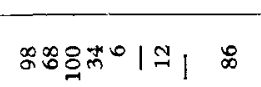 & in & F & i़ \\
\hline 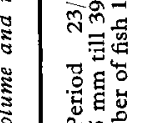 & 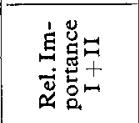 & 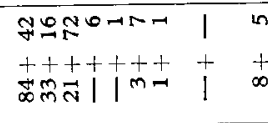 & $\begin{array}{l}0 \\
0 \\
9 \\
0 \\
0\end{array}$ & 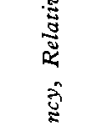 & 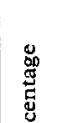 & H & 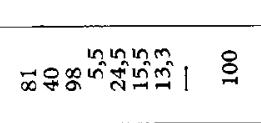 & 8 & $\vec{b}$ & $\underbrace{n}_{0}$ \\
\hline 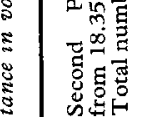 & 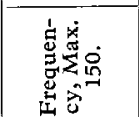 & 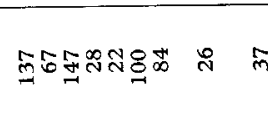 & & 离 & 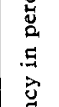 & $m$ & 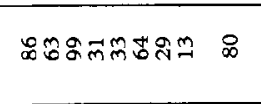 & 8 & in & $\begin{array}{l}i 0 \\
\prod_{m}^{0}\end{array}$ \\
\hline 愿出㟧 & 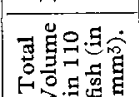 & 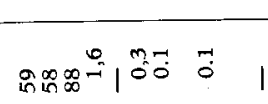 & & 总 & 䔅 & N & 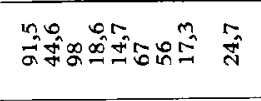 & in & ते & $\prod_{\infty}^{p}$ \\
\hline 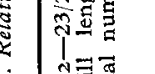 & 宝总 & 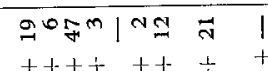 & 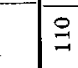 & & & - & त̂ં & $\stackrel{9}{ }$ & $\vec{\alpha}$ & $\prod_{\substack{\infty \\
0 \\
0}}^{\infty}$ \\
\hline & 运 & 的些守 $|1|=-1$ & $\cong$ & & & & & & & \\
\hline 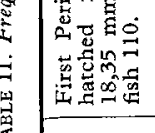 & 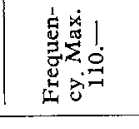 & 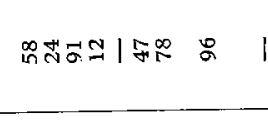 & & & & $\therefore$ & 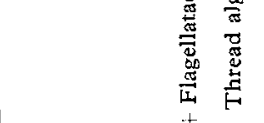 & 足 1 & 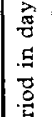 & \\
\hline & & 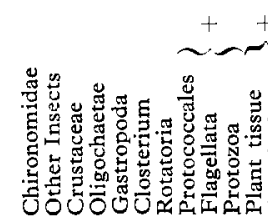 & $\begin{array}{l}2 \\
4 \\
4 \\
0 \\
H \\
H\end{array}$ & & & $\ddot{\nu}$ & 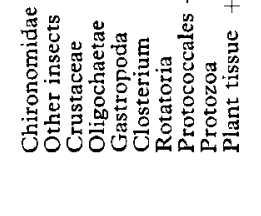 & 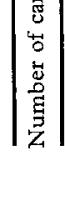 & 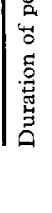 & \\
\hline
\end{tabular}


9. Thread algae, mainly Spirogyra and Hydrodiction, are listed together with plant tissue, derived from higher aquatic plants such as Hydrilla verticillata, and detritus of allochthonous origin, in our case also from decaying Tithonia leaves thrown in as green manure.

With the aid of the above explanations the tables illustrating the guts contents of the carp during growth will be understood.

\section{THE DIET OF THE COMMON CARP IN THE BOGOR HATCHERY}

The overall results of the five successive periods are given in table II in terms of frequency, relative importance judged by total volume, and total volume in $\mathrm{mm}^{3}$. In table III the figures have been converted into percentages.

From a study of these tables we wish to draw the following conclusions, discussing the nine groups in turn.

1. Chironomidae are found to form a most important item, even for the very young fry. In the samples of the first period some headcapsules of Chironomidae were measured, in order to compare the dimensions of the prey with those of the predator.

Table IV - an extract from our files - gives an idea of the importance of midge-larvae for the very young stages of carp under the circumstances observed, during the first period.

TABLE IV

Numbers and dimensions of Chironomid larvae found in the guts of carp fry, immediately after hatching. (First period) Number of fry: 10 carp each date.

\begin{tabular}{rcccc}
\hline Date & $\begin{array}{c}\text { Days after } \\
\text { hatching }\end{array}$ & $\begin{array}{c}\text { length of } \\
\text { fry in mm }\end{array}$ & $\begin{array}{c}\text { Chironomidae } \\
\text { number }\end{array}$ & $\begin{array}{c}\text { Chir. width of } \\
\text { head-capsule } \\
\text { in } \mu\end{array}$ \\
\hline $2 / 2$ & 2 & 7.50 & 2 & 100 \\
$4 / 2$ & 4 & 8.82 & 4 & - \\
$6 / 2$ & 6 & 11.25 & 2 & - \\
$8 / 2$ & 8 & 12.35 & 0 & - \\
$10 / 2$ & 10 & 14.45 & 20 & - \\
$12 / 2$ & 12 & 14.00 & 12 & - \\
$14 / 2$ & 14 & 15.40 & 20 & - \\
$16 / 2$ & 16 & 16.90 & 35 & - \\
$18 / 2$ & 18 & 17.40 & 17 & - \\
$20 / 2$ & 20 & 17.00 & 18 & - \\
$22 / 2$ & 22 & 18.35 & 54 &
\end{tabular}

In this table the data for each date are the averages, (width) c.q. the sums (number) for 10 fry. It will be seen that Chironomidae 
were eaten from the very first day food was ingested and that these larvae increased in importance throughout the period. By comparing the first with the following periods it will be seen that later on Chironomidae still increase and remain important throughout growth. However, it is also evident that these larvae do not hold the primary position ascribed to them by many European authors. The difference found in our case might be explained by a different availability of other sources of food. In the extreme environment of the "karamba's" 1 ) in the sewers of Bandung, for instance, Chironomidae and Oligochaetae actually formed the main source of food. (VaAs \& Sachlan, Proceedings of I.P.F.C. 6th Meeting, Tokyo, in the press.).

2. Other aquatic insects and their larvae were taken in many cases and in increasing numbers as the fry grew older. Their importance is always less than that of the midgelarvae. Living in the open water or among the littoral flora most of them belong to a quite different ecological group. As will be shown in the next Section these animals are far less frequent than midge-larvae.

3. Crustaceae - Cyclopidae, Cladocera and Ostracoda - formed the most important item from the beginning of growth to the end of our experiment, according to all three criteria.

In this case the ideas of WUNDER on this group were fully confirmed. On the 4 th of February fry of an average length of 8.82 $\mathrm{mm}$ consumed Cyclopidae measuring $260 \mu$ in width. In later stages large numbers were often found in a single intestine. On the 14th of July 16137 Cyclopidae were found in the guts of 10 carp measuring $108.6 \mathrm{~mm}$ in average length. The largest number encountered in one fish was 6900 .

4. Oligochaetae were neither frequent nor important in our pond. For an entirely different situation we refer again to the Bandung ,karamba's". Here mass-availability caused this group to be of primary importance.

5. Gastropoda were not ingested in the first stages, the digestive apparatus of the fry being, probably, too weak to crush the shells of even the smallest snails. They gained some importance later on.

6. Closterium. In this case the opposite situation is found. These large cells were eagerly ingested by the very young fry, but gradually lost their importance and were not eaten at all in the last stage. The total quantity was always small.

7. Rotatoria hold a position similar to that of Closterium.

8. Protococcales, together with Flagellatae and Protozoa, show the characteristics of the two previous groups in an even more

1) bamboo cages where carp are grown in running sewage. 
pronounced way. Owing to the small size of the cells they do not materially add to the volume of food ingested by the tiny fry. As was stated above, the digestibility is bad and these cells are not ingested any more when the carp has reached a larger size.

Diatoms were often ingested but never in appreciable quantities.

9. Plant tissue and Thread algae are not ingested during the first period. From the third period on this item is most frequent and is found during the three later periods with frequencies of resp. $80-100$ and $86 \%$. In $24-59$ and $16 \%$ of all cases it formed the main food by volume, occupying resp. $21-36.4$ and $13 \%$ of the food by volume. For these figures digestibility had to be estimated. The volumes used for calculation were those that were estimated to be actually digested. Consequently vegetable food of this type formed an important item in our case, although less important than each of the groups of Chironomidae and Crustaceae. Teh weekly supply of horse-manure and Tithonia twigs will have increased the availability of easily digestible vegetable food in our pond.

In Europe voN MALTZAN (l.c.) emphasized its importance and vegetable tissue and grass seeds (Glyceria) have been found in the guts by many authors. This is in accordance with the use of cereals and pulses as fodder. However in Wunder's numerous analyses this group was not so important. MOEN (1.c.) investigating the food of 687 carp from 14 lakes in Amerika, found that vegetable debris, pieces of the tissue of living aquatic Phanerogames and seeds were taken, forming about $10 \%$ of the food in summer, but almost entirely absent in winter, and mainly ingested when other food was scarce.

In many cases carp were reported to destroy aquatic vegetation in American open waters (CAHN 1929, ThreINEN \& HeLM 1954), and experiments, especially designed by TRYSON (1954), had the same results. However, this is not the effect of consumption of the plants by the carp, but of the vigorous way large carp churn up the bottom mud in search of food and thus uproot the plants and increase the turbidity of the water so as to intercept sunlight indispensable for vegetation.

Comparing the evidence obtained according to the three different criteria, we arrive at the following order of importance, shown separately for fish smaller than $40 \mathrm{~mm}$ - periods I and II and for those larger than $40 \mathrm{~mm}$ - periods III, IV and V. (Table V).

The difference between small and large fry - importance of single-celled algae and Rotatoria, absence of Gastropoda - was already mentioned above. Aquatic insects and their larvae form 
TABLE V

Order of importance of nine categories of food, according to three criteria, for carp measuring less than $40 \mathrm{~mm}$, and for carp measuring from $40-135 \mathrm{~mm}$ total length.

Carp less than $40 \mathrm{~mm}$.

\begin{tabular}{|c|c|c|}
\hline FREQUENCY & REL. IMPORTANCE & TOTAL VOLUME. \\
\hline Crustaceae & Chironomidae & Crustaceae \\
\hline Chironomidae & Crustaceae & Insects \\
\hline Rotatoria & Insects & Chironomidae \\
\hline Closterium & Rotatoria & Plant tissue \\
\hline Protococcales etc. & Plant tissue & Closterium \\
\hline \multicolumn{3}{|c|}{ Carp from $40-136 \mathrm{~mm}$. } \\
\hline Crustaceae & Plant tissue & Crustaceae \\
\hline Chironomidae & Chironomidae & Plant tissue \\
\hline Plant tissue & Crustaceae & Chironomidae \\
\hline Insects & Insects & Insects \\
\hline Closterium & Gastropoda & Gastropoda \\
\hline
\end{tabular}

fairly large individual quantities of food. If a small fish happens to catch them, they contribute materially to the total volume ingested. This explains the high order of this group in the case of the smaller fry.

The primary position of Crustaceae and Chironomidae stands out clearly in this table. Vegetable food seems to have been playing an important role mainly during the long fourth period, probably the regular supply of Tithonia and horse manure had some influence here.

It is of interest to compare these results with those of WUNDER, being a summary of the examination of the guts contents of 534 large carp from Silesian ponds, and given in table VI.

\section{Table VI}

Composition in \% of the guts contents of 534 large crap from Silesian ponds. Measurements by weight. (after WUNDER 1949).

\begin{tabular}{rcccc}
\hline & planktonic & littoral & bottom & total \\
\hline Crustaceans & 57 & 3 & - & 60 \\
Chironomidae & - & 10 & 7 & 17 \\
Other Insects & - & 23 & - & 23 \\
\hline Total & 57 & 36 & 7 & 100
\end{tabular}

This table was based on calculations from which the amount of vegetable food was omitted, because - according to WUNDER this was not important.

It will be seen that planktonic Crustaceae exceeded the midge and 
other larvae taken from the bottom and the littoral zone. WUNDER's ponds in Silesia are materially deeper than ours.

This might explain the difference in the importance of vegetable food, of which relatively more will have been present in our pond both from autochthonous and allochthonous sources - than in WUNDER's ponds. From these findings Wunder drew the conclusion that his carp were not typical ,bottom feeders" and we can support this statement. As our pond is much shallower than those studied by WUNDER, its bottom - fauna must be relatively more important than the Crustaceae of the littoral zone and the open water. Still we find Crustaceae to be of primary importance.

\section{RELATIONSHIPS BETWEEN FOOD AND GROWTH}

In the previous chapters only overall results per period have been given. However, if we try to analyse the relationships between the quantity and quality of food ingested and growth measured in terms of increase in length of body and guts, as well as in terms of the changing ratio between length and body height of the fish, some interesting points are revealed.

Studying fig. 1 and 2, where the 5 periods are shown in two figures, using different scales for length of body and guts and for volume of guts contents in either case, we see that in the first four periods growth of body and intestine starts rapidly and slows down towards the end. As the last period was rather short, growth was interrupted here before it began to slow down. The ratio between length and height of the fish decreases rapidly at first and slowly afterwards, showing that the fry becomes relatively higher as it grows. During the periods of slow growth of body and intestine this ratio shows temporary interruptions in its downwards slope.

In these figures every point concerning measurements of the body of the carp is an average of 10 fish taken at random out of a number decreasing every time the pond was thinned out, (table I) and every point concerning volume of intestinal contents depicts the total quantity of the guts of 10 fish.

On the 13 th of Augustus when the experiment ended, it was possible to check the accuracy of sampling. Previous to the cropping of the entire population a sample of 10 was taken in the usual way. The average length of those 10 fish was $13.66 \mathrm{~cm}$. Then the remainder was landed and all 134 fish measured. The average length proved to be $13.56 \pm 0.081 \mathrm{~cm}$, with a standard deviation $=0.938$.

For this reason it is assumed that all previous samples were representative as well. 


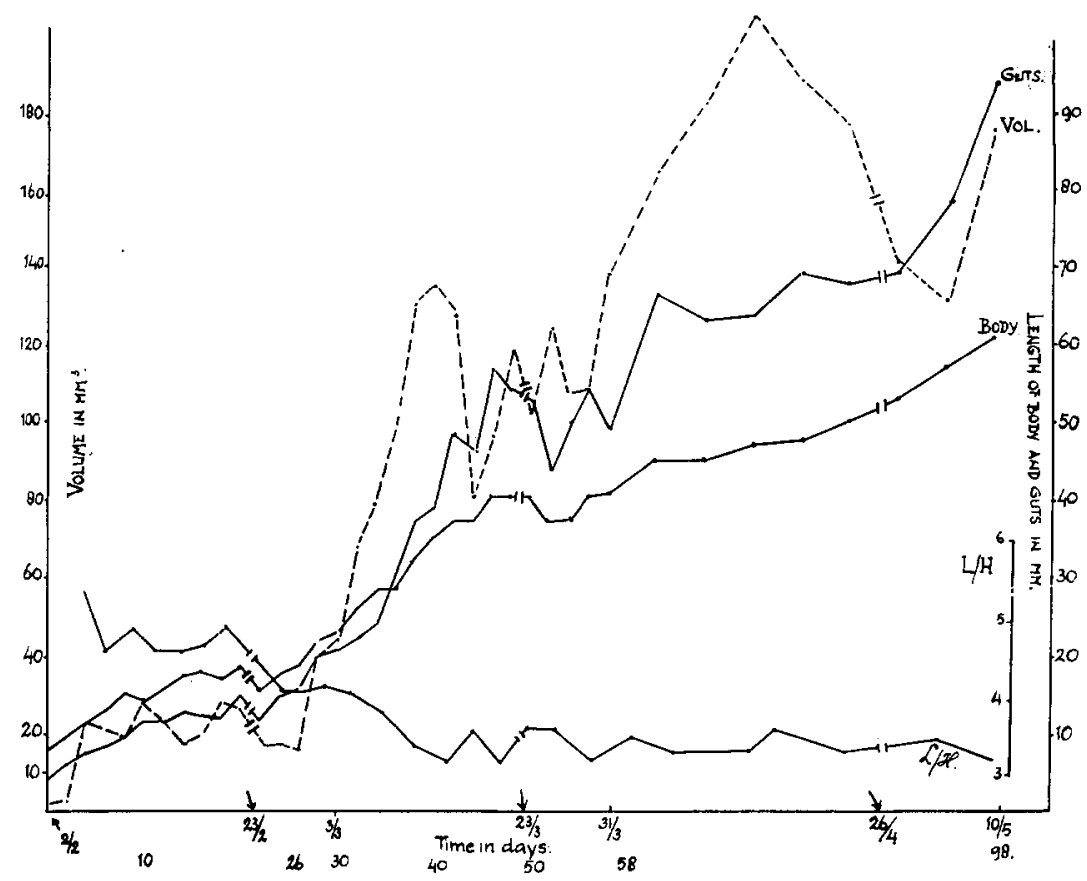

Fig. 1. Growth of the body and the guts of common carp fry in ponds in Bogor, together with the total quantity of digestable food in the guts of 10 fish and the ratio between total length and height of the body (average of 10 fish). First part.

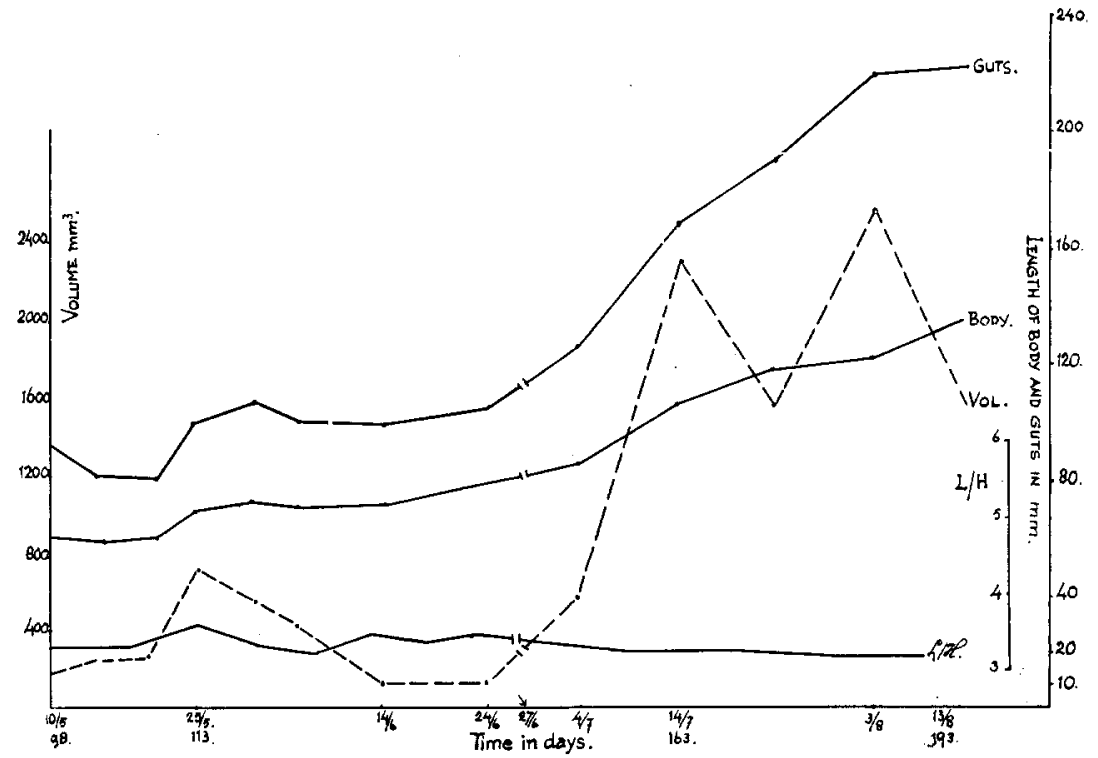

Fig. 2. As Fig. I, second part (different scales) 
It will be seen that the volume of food ingested also shows a decline towards the end of each period, concomitant with the general decline in the rate of growth. It seems that under the conditions studied, after one month certain limiting factors come into play decreasing the amount of natural food suitable for rapid growth. In the next Section, where biota were sampled simultaneously with guts contents, more will be said on this subject.

In figs. 3, 4, 5, 6 and 7 the volumes of the various groups of natural food of quantitative importance are separately shown for every period

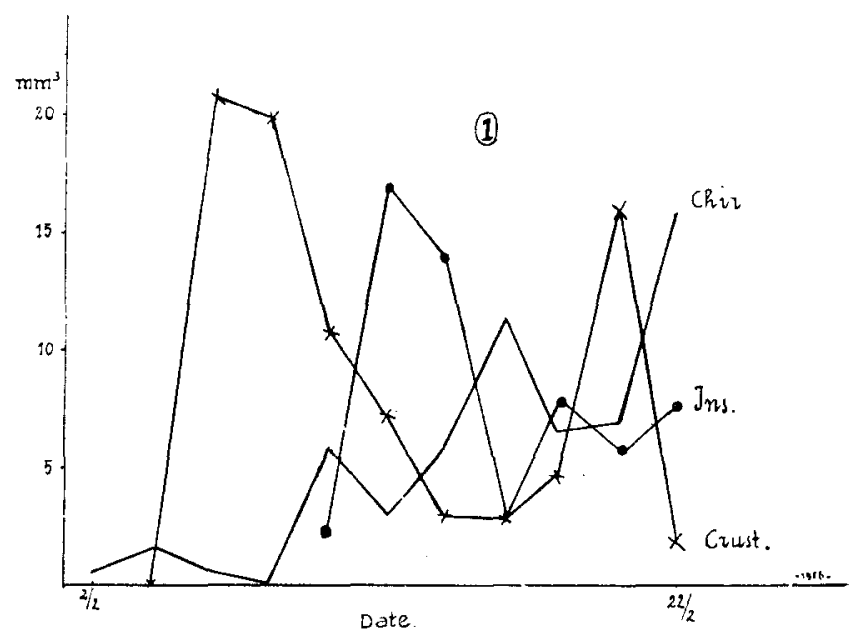

Fig. 3. Changes in composition of the guts contents during growth. Total volume for 10 fish. First period.

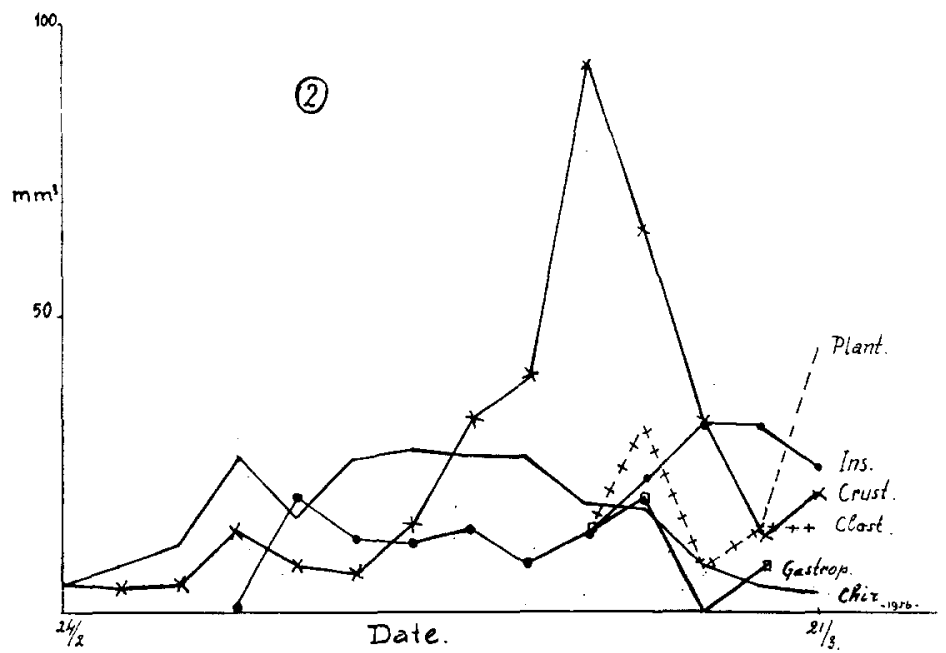

Fig. 4. As Fig. 3. Second period. 


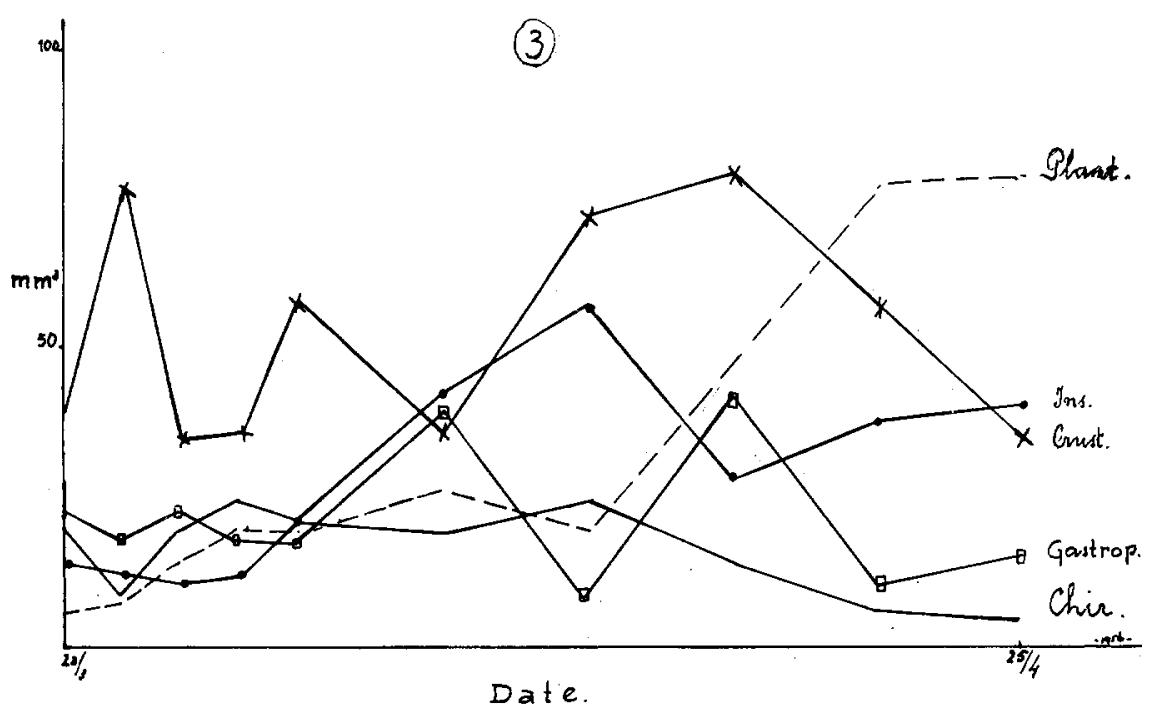

Fig. 5. As Fig. 3. Third period.

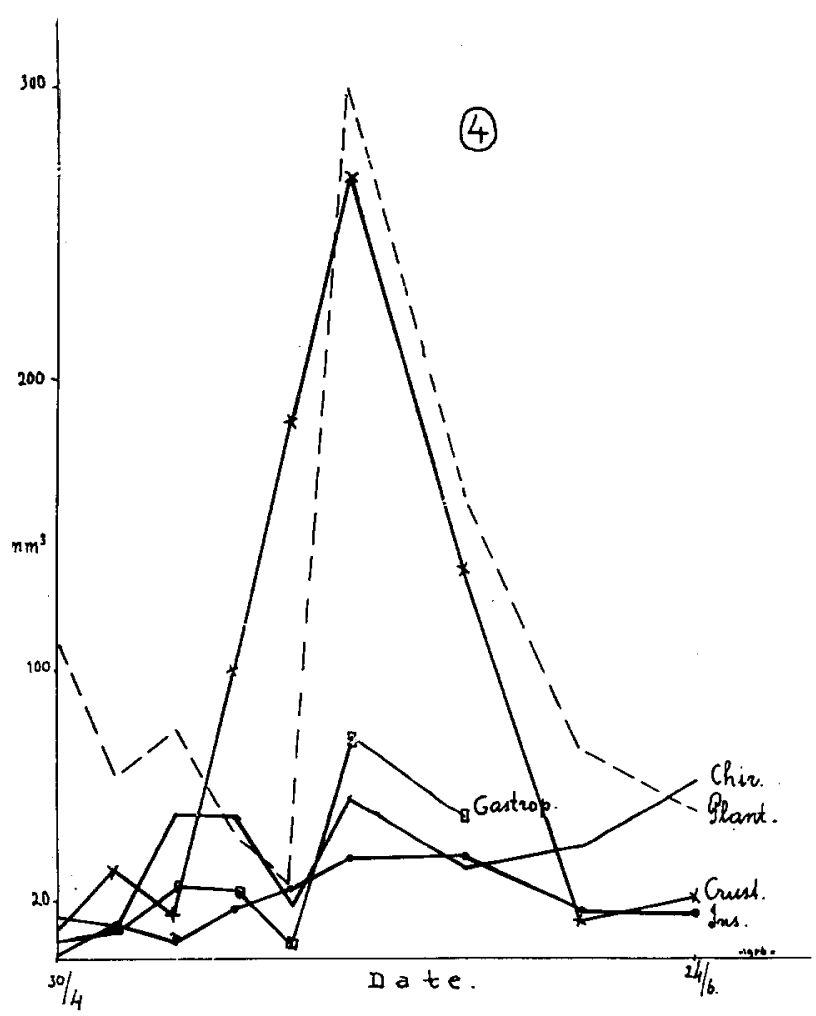

Fig. 6. As Fig. 3. Fourth period. 


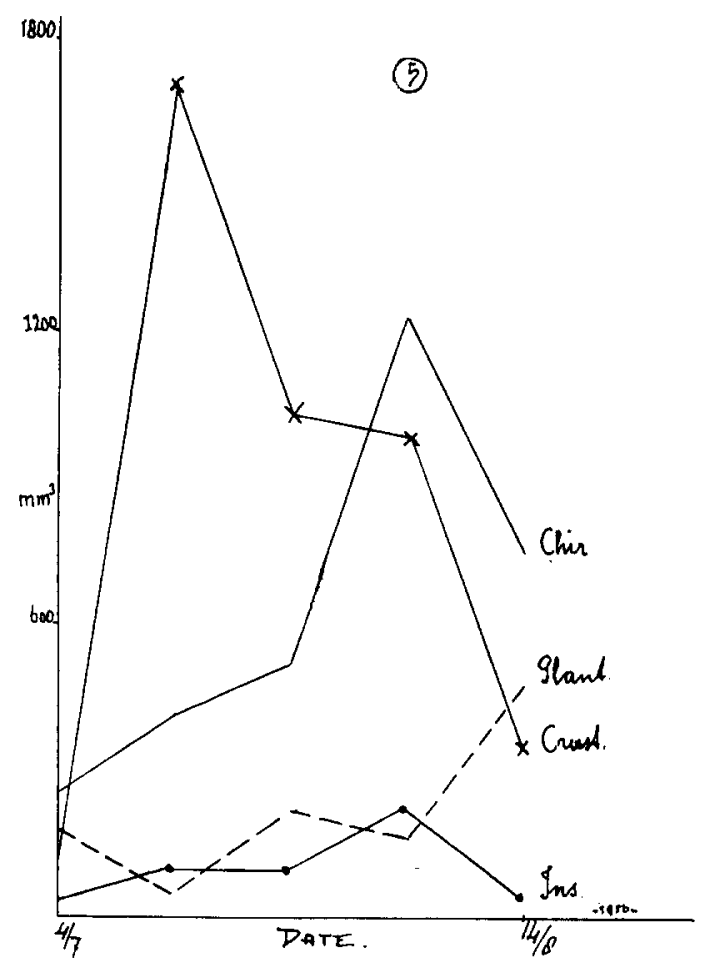

Fig. 7. As Fig. 3. Fifth period.

of growth. As availability of food in the pond was not studied at this stage, it is difficult to analyse the feeding habits of the growing carp here.

All writers who studied this phenomenon agree that the occurrence of pond-biota is most erratic and that sudden rises and falls are common for many organisms. As the carp is a pronounced polyphagous species, availability will dictate its food to a marked extent.

Besides showing polyphagous feeding habits the carp shows pronounced individual differences in its choise of food, as was evident in nearly all our samples, where always 10 carp feeding under exactly similar conditions were examined. We have tried to circumvent this disturbing influence by using the sum of the guts contents of 10 fish each time.

If we study the different lines for each group in the figures, we find that a large majority of them roughly show an optimum curve, with the exception of the line for vegetable food, which in 3 out of 4 cases shows an increase towards the end. (Table VII). 
TABLE VII

General trend of graphs showing the fluctuations of the total volume of various groups of natural food in the guts of 10 carp, during 5 periods of growth.

\begin{tabular}{|c|c|c|c|c|c|}
\hline Period & I & II & III & IV & V \\
\hline Chironomidae & rising & optimum & optimum & $\begin{array}{c}\text { rising } \\
\text { weakly }\end{array}$ & optimum \\
\hline Other Insects & optimum & $\begin{array}{l}\text { optimum } \\
\text { weak }\end{array}$ & optimum & optimum & optimum \\
\hline $\begin{array}{c}\text { Crustaceae } \\
\text { Gastropoda } \\
\text { Plant tissue } \\
+\end{array}$ & $\begin{array}{c}\text { optimum } \\
-\end{array}$ & optimum & $\begin{array}{l}\text { optimum } \\
\text { optimum }\end{array}$ & $\begin{array}{l}\text { optimum } \\
\text { falling }\end{array}$ & optimum \\
\hline Thread algae & - & rising & rising & optimum & rising \\
\hline
\end{tabular}

These findings seem to indicate that towards the end of each period, when growth slows down owing to scarcity of other food, more vegetable food of inferior nutritional value, is taken in.

For European and American common carp similar views are held by most authors, as was stated in a previous chapter. It will be seen that in our findings vegetable food formed a larger percentage, and was more often ingested, than in most cases abroad.

This must not be seen as a preference but as a necessity arising from a shortage of other food, and as a result of the supply of horse and green manure, making easily digestable vegetable food readily available.

\section{SECTION 2.}

RELATIONSHIP BETWEEN THE GUTS CONTENTS OF COMMON CARP GROWING IN A POND OF THE HATCHERY AT BOGOR AND AVAILABILITY OF NATURAL FOOD, SIMULTANEOUSLY SAMPLED. INFLUENCE OF THE CARP ON DEVELOPMENT AND GROWTH OT OTHER POND BIOTA.

\section{MATERIAL AND METHODS}

The experiments to be related in this Section were carried out in order to supplement our previous findings with data on the availability of natural food organisms and also to study the influence of the carp on development and growth of those organisms.

For this reason 4 ponds of the Hatchery, entirely comparable to the one mentioned in the first Section, were used. Two were stocked with common carp, two were left unstocked. Every week the following observations were made:

1. Netplankton, from 10 litre. 


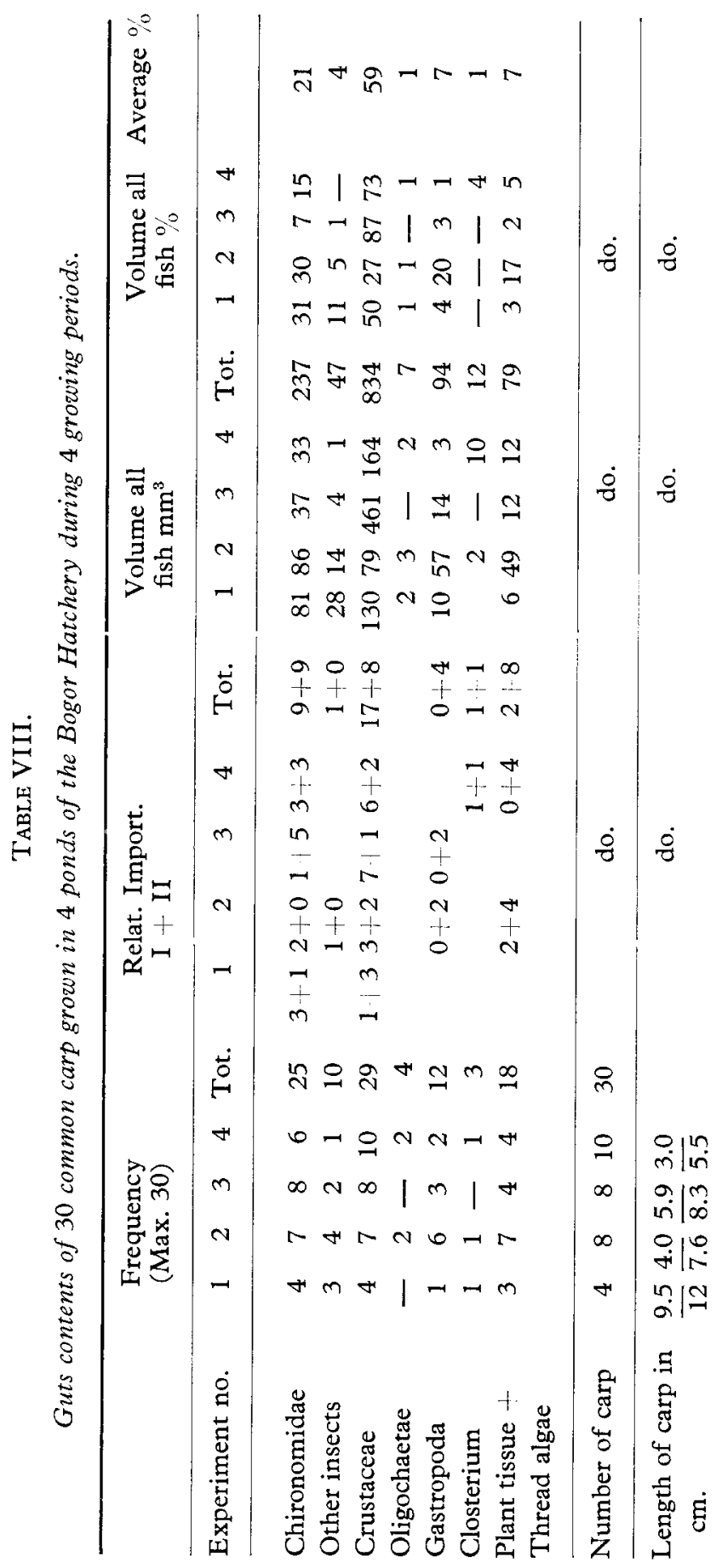


2. Nannoplankton from 10 litre, using the Iodine-sedimentation method.

3. Organisms from the mud. Eight samples of $1 \mathrm{~cm}^{2}$ were taken with a glas rod at different places of the pond.

4. Weight of 10 carp taken with a small bow net. A small amount of faeces was gently pushed out of the vent and immediately preserved in formaline. The carp were than released.

5. Guts contents of various other pond biota.

6. Littoral fauna and microflora was studied in 10 one-litre samples taken along the entire embankment of the pond. The data obtained are shown in the tables in a semi-quantitative way only.

At the end of each period two to five fish from each pond were cut open and the entire guts sampled. A total number of 30 carp was studied.

The experiment was repeated 4 times with different stocking rates according to the momentary availability of fry. Stocked and unstocked ponds were changed each time, in order to avoid cumulative effects and possible effects of minor topographic differences. This arrangement has the disadvantage of the possibility of after effects of previous stocking in unstocked ponds. Another unavoidable disadvantage was the change of the seasons. The first period - August - took place during the dry, the fourth during the rainy season. However there differences are not comparable to seasonal changes in temperate zones.

Out of every plankton sample $0,02 \mathrm{cc}$ was counted twice. Numbers were converted to volumes as in the previous Section, and expressed per litre.

Mud samples were treated as plankton samples after all organisms larger than $1 \mathrm{~mm}$ had been picked out by hand under a binocular microscope. Chironomidae and Oligochaetae formed the bulk of the latter group.

Faeces were treated as guts contents. After the volume of each group had been ascertained they were expressed in the tables as percentages of the total amount. Total volume is irrelevant in this case as the total quantity will be erratic.

Organisms too big to be sampled with the net or the tube were not studied quantitatively but some specimens were regularily taken and their guts contents studied in the lab. Some names have been mentioned earlier. 
In total the entire guts contents of 30 carp were studied. As Rotatoria and organisms in previous tables combined into the groups Protozoa, Flagellatae and Protococcales, proved to be unimportant for these, somewhat bigger, fish both groups were deleted in the tables.

In table VIII the guts contents are shown according to the same criteria as used in previous tables.

It will be seen that the results of each of the four growing periods do not differ much and that the overall results are similar to those obtained in the previous experiment. As no additional green manure was added this time less vegetable matter was found in the guts.

In table IX the different groups were listed according to their importance as natural food for the common carp using the three criteria separately.

TABLE IX.

Importance of natural food for 30 common carp grown in Bogor Hatchery in 4 periods.

$\begin{array}{lll}\text { Frequency } & \text { Relative Importance } & \text { Volume } \\ \text { Crustaceae } & \text { Crustaceae } & \text { Crustaceae } \\ \text { Chironomidae } & \text { Chironomidae } & \text { Chironomidae } \\ \text { Plant tissue } & \text { Plant tissue } & \text { Gastropoda } \\ \text { Gastropoda } & \text { Closterium } & \text { Plant tissue } \\ \text { Insects } & \text { Gastropoda } & \text { Insects } \\ \text { Oligochaetae } & \text { Insects } & \text { Closterium } \\ \text { Closterium } & & \text { Oligochaetae }\end{array}$

The order according to the different criteria is exactly the same for the two most important groups and does not differ much for the others.

Again Closterium was only important in those cases that small fry was used (Exp. no 2 and 4).

The relationship between guts contents and instantaneous supply of natural food is shown in tables X, XI, XII and XIII. Here the guts contents are shown for the total number of fish from each pond separately in each period. The numbers of organisms are shown and not the volumes as in previous tables because the same was done for food supply. Pond biota were sampled every week but only the data for the dates of cropping are shown because at these days the guts were collected. In accordance with the way of sampling, as described earlier, the data are divided into biota from the open water, from the mud on the bottom and biota among the shore vegetation. It must be admitted that organisms found in the guts have been ingested by the 


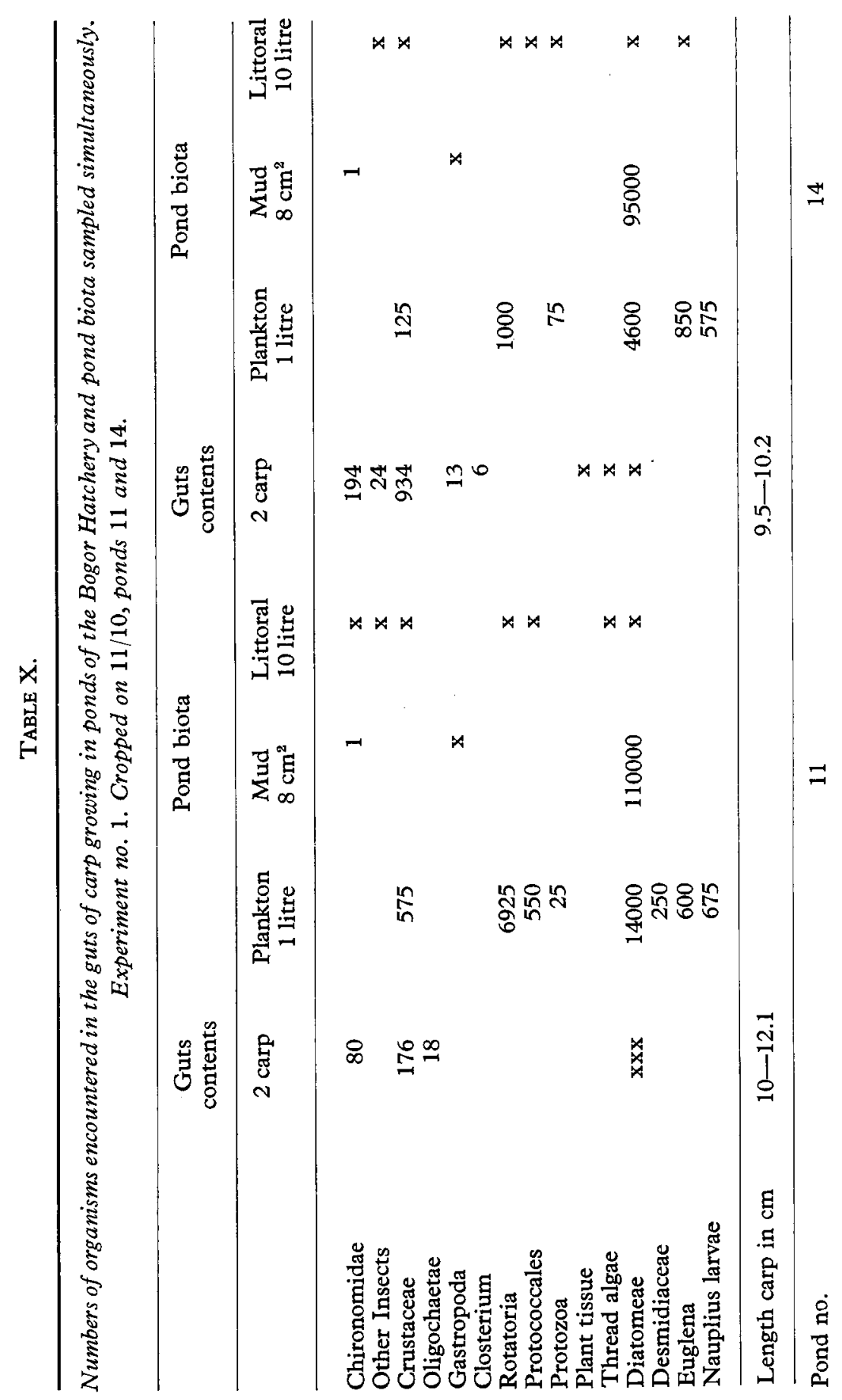




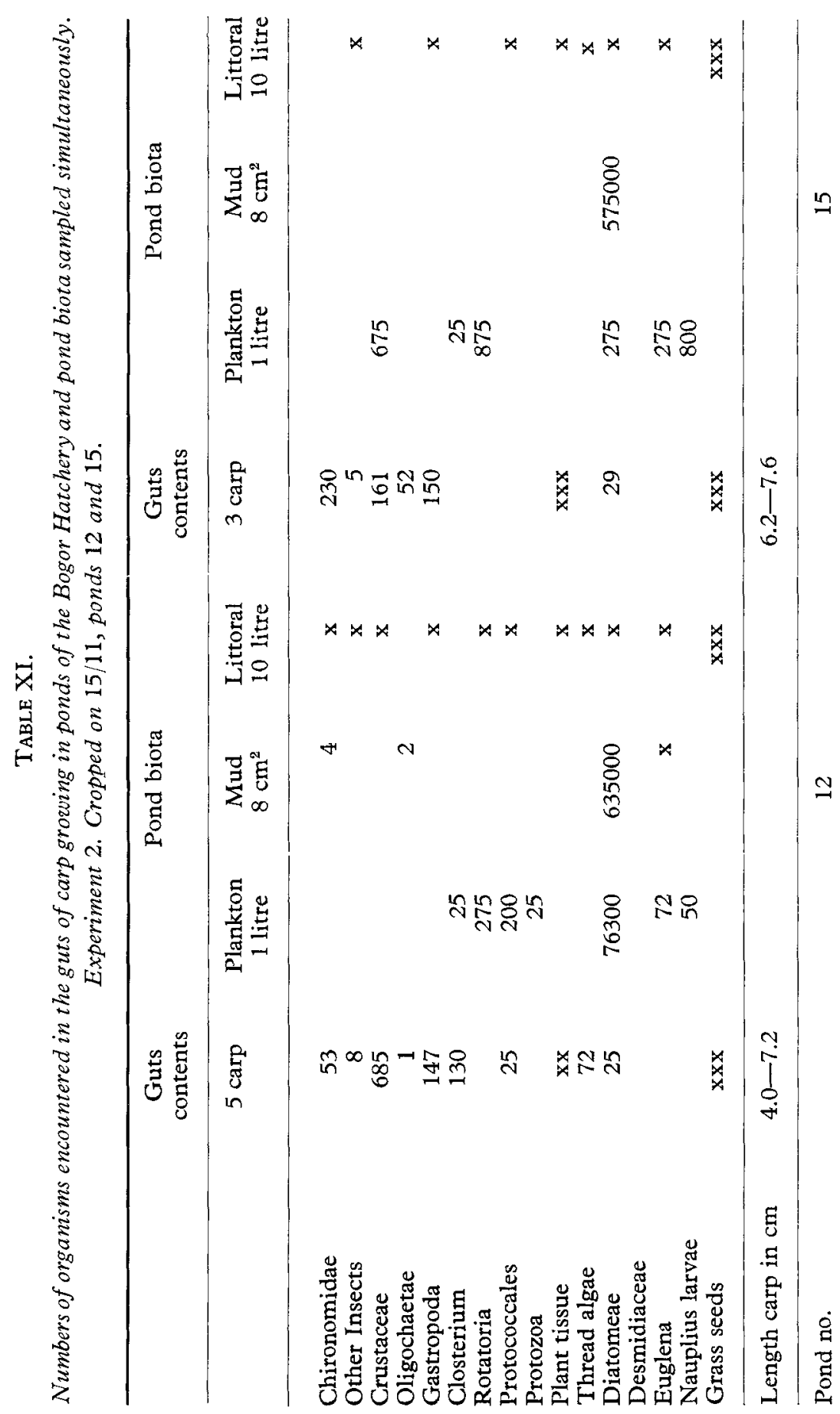




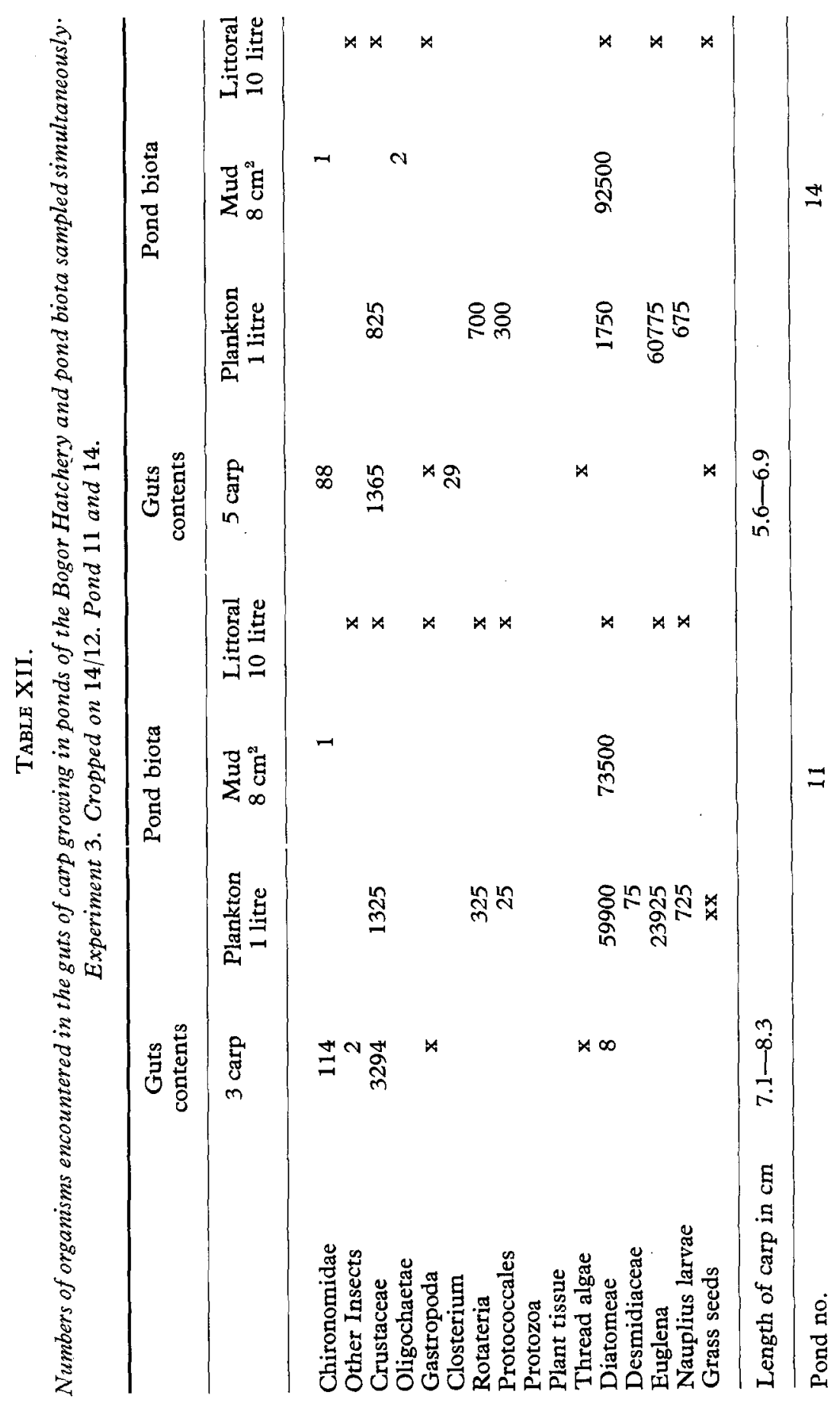




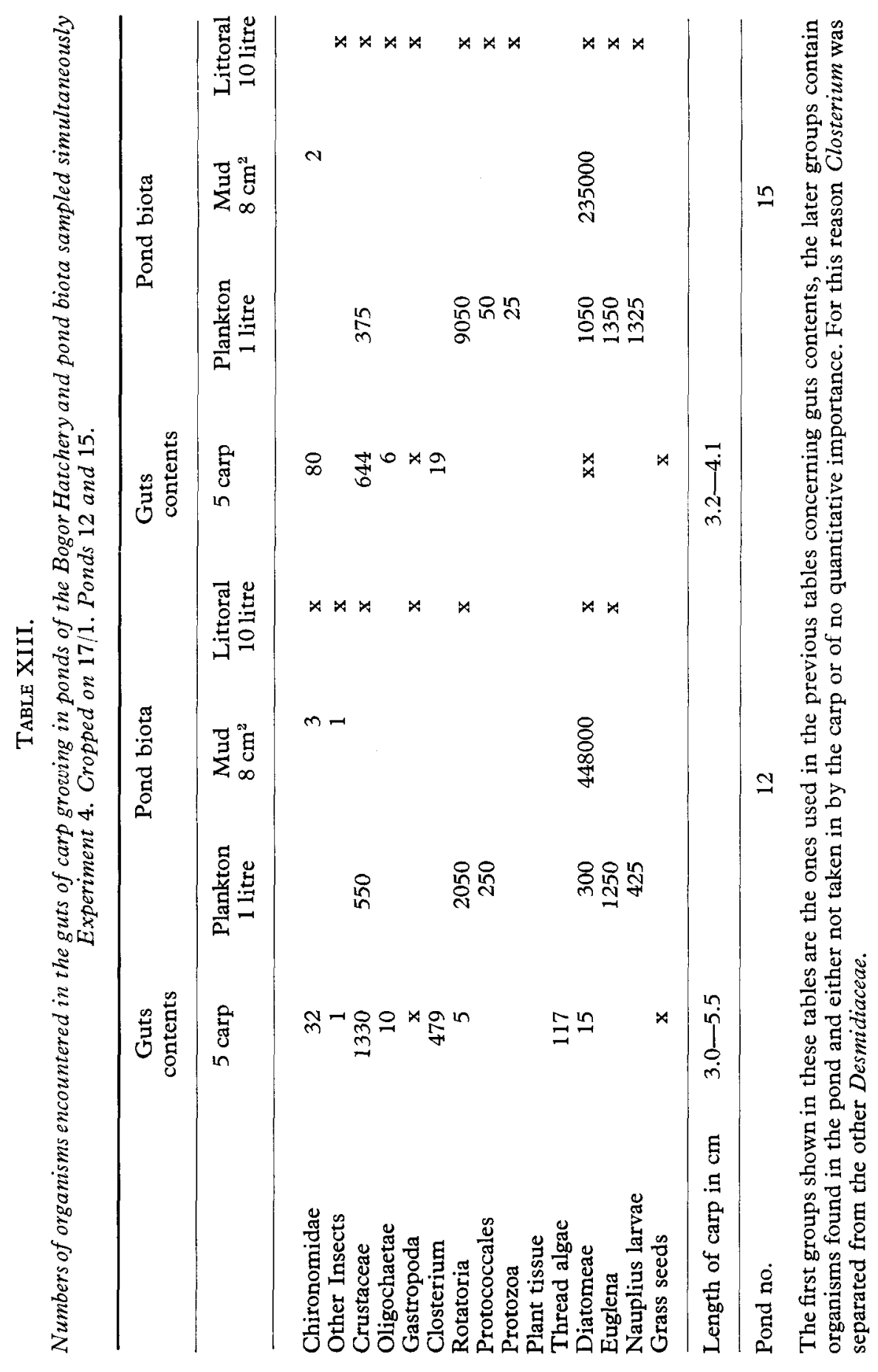


carp some hours earlier than those sampled from the pond at the moment the fish were caught.

Previous studies revealed a slight diurnal movement of Crustaceae in our ponds (VAAS \& SACHLAN, 1955), rising to the surface at night. Thus Crustaceae might have been slightly more readily available to the carp, feeding in all strata of the water, than is revealed in our samples, where 10 times 1 litre was taken. However in the third Section carp were collected every 4 hours during a period of 24 hours and no reliable differences were found in the numbers of Crustaceae in the guts.

Table XIV gives a list of the organisms of the ponds ecosystem.

TABLE XIV.

List of biota living in the ponds of the Bogor Hatchery.

Plankton

Volvocales Pandorina, Eudorina.

Chlorococcales Dictyosphaerium, Golenkinia, Pediastrum, Scenedesmus.

Desmidiaceae Cosmarium, Closterium.

Diatomeae Melosira, Navicula

Chloromonadineae Euglena.

Cyanophyceae Nostoc, Lyngbya.

Rotatoria Filinia, Asplanchna, Rotifer, Brachionus, Polyarthra,

Cathypna.

Crustaceae Bosmina, Diaphanosoma, Macrothrix, Ilyocryptus, Mesocyclops, Cypris.

In the mud samples

Coelenterata Hydra.

Oligochaetae Nais, Branchiodrilus, Pristina, Dero, Aulophorus, Limnodrilus, Branchiura.

Chironomid larvae Tanytarsus, Eutanytarsus, Chironomus, Endochirinomus, Limnochironomus, Tendipes, Glyptotendipes, Pelopia, Macropelopia, Protenthes.

Mollusca Melania, Paludina.

Nematoda

Not quantitatively sampled:

Crustaceae Paratelphusa

Insecta Notonectidae, Corixidae.

Pisces Lebistes

Amphibia Frog larvae.

Based on the data of the above tables, supplemented with the evidence obtained from a study of the guts contents of various other biota, the following picture is obtained of food relations within the ecosystem of the pond.

The guts contents of the common carp have been described. In the guts of Lebistes we found the same organisms but for Gastropoda. 
Planktonic Crustaceae, adult aquatic insects and Rotatoria subsist mainly on phytoplankton, barring some aquatic insects attacking fish fry. Moreover Rotatoria eat bacteria from the water and from the upper layers of the mud. Crustaceae also eat minute phytoplankton und epiphyton from the vegetation around the bunds and detritus. The Ephemeridae larvae found among the littoral flora subsist on epiphyton and phytoplankton. Oligochaetae, Chironomidae and snails ingest the mud on the bottom, consisting of organic detritus of allochtonous origin, the remains of dead plants and animals, the bacteria responsable for the decay of the organic substances and the benthic algae taking in the released minerals.

Tadpoles and crabs take up an exceptional position in so far that these organisms, living exclusively on vegetable matter - in the guts of the crabs coarse plant material only was found - and for this reason accelerating metabolic processes in the pond, are hardly ever eaten by other animals in this environment. Minerals are stored in their bodies for this reason. Tadpoles will eventually leave the pond after completing their metamorphosis and crabs can crawl to some other pond and are captured by the hatcherymen during cropping.

This qualitative picture might suffice at this stage for our present aim, a comparison between the supply and utilization of natural food in these ponds. The ecosystem will be referred to in greater detail after the description of quantitative relations in the second part of this chapter. At the end of the paper conditions in these Bogor ponds will be compared with those in a pond at Bodjong Loa, Bandung.

It will be seen in the above tables that the food organisms encountered this time and also during the investigations related in the first section, in the guts of the common carp were readily available, either in the open water - Crustaceae - or in the mud - Chironomidae and Oligochaetae and some Gastropoda -, or among the littoral flora - insect larvae. The large supply of Diatomeae, Protococcales, Euglena is not touched. Among the Desmidiaceae only the large Closterium is of some importance. The small-celled Rotatoria are hardly taken. Nauplii were frequently found in the pond but could never be ascertained in the guts. Severe crushing of the cells inside the guts makes identification difficult. So we are not in a position to state that Nauplii are not eaten at all.

The picture obtained in the first section, that the carp is a polyphagous, opportunistic feeder of natural food whenever available in the form of not too small size in the open water, on the bottom and among the shore vegetation, is confirmed.

In the second part of this section the study of our weekly samples taken in the pond and supplemented with the investigations of the faeces of the growing carp, will be treated in an attempt to study the 
continuous changes in the composition of the biota as a result of the feeding activities of the carp. Here the weekly samples taken in the unstocked ponds will have to act as controles. With the methods described a fairly quantitative picture can be obtained of the supply of organisms forming the main food of the carp - Crustaceae, Chironomidae and Oligochaetae, as well as of those organisms making up the main food of the Crustaceae - phytoplankton. The supply of food for both Chironomidae and Oligochaetae could not be evaluated, but this supply might be assumed to be large, as benthic algae will grow profusely in these lively inhabitated ponds, where sunlight can reach the entire bottom. Dead and live algae will be readily available on the bottom. Moreover the number of Chironomidae larvae depends on the number of eggs and the number of ovipositing females will be independent from the amount of food on the bottom. According to experiments by SADLER (1934) and WIRSHUBSKY \& ElCHUNES (1952) more eggs are deposited in ponds previously treated with organic manure. However inorganic fertilizers do not show this phenomenon and in the latter case the availability of food on the bottom will be increased as well. The effect of manuring is thought to consist of the production of chemical substances attracking the imagines.

The organisms counted were divided into the following groups:

1. Phytoplankton (both net- and nannoplankton) barring Euglena. This organism is often found in enormous numbers as a surface film, frequently accumulated in a corner of the pond by wind action. For this reason it is difficult to obtain reliable samples and moreover the large numbers could influence the phytoplankton data to a marked extent. The cysts of Euglena are undigestable for many organisms and for all these reasons we wish to treat Euglena separately from other algae sampled with the plankton net. In giving separate values for Euglena we are well aware of their relative unreliability.

2. Rotifera.

3. Nauplius larvae. Subsisting on phytoplankton and some detritus, these larvae are apparently not eaten by our carps and only to a limited extent by Lebistes. Their number depends on the number of adults able to produce them before they are devoured themselves.

4. Chironomidae are combined with the usually less frequent Oligochaetae. They live on detritus- barring the few carnivorous species $^{1}$ ) and are eaten by the carp.

1) Although Pelopia is a carnivorous genus according to the literature, we only found vegetable matter in the guts and never any animal remains. 
The numbers of these organisms were converted into volumes. In the tables and figures showing the results of the relevant experiments the average weight of 10 fish is likewise shown, forming together a growth curve of the carp. These 10 carp were restocked after some faeces were pushed out of the vent. In the tables and figures the weekly percentage of Crustaceae and Chironomidae - Oligochaetae is shown. The four experiments will be described separately.

\section{Experiment 1.}

10/9 untill $11 / 10$. Ponds 12 and 15 unstocked, ponds 11 and 14 stocked with 120 carp, total weight 770 gram. Results: pond 11 cropped 106 carp, total weight 1673.5 gram - increase: 903.5 gram , pond 14 cropped 91 carp, total weight 1380 gram - increase 610 gram.

Data pertaining to this experiment are given in table XV and figures 8 and 9. After one week an outburst of phytoplankton occurred in all ponds composed of Dictyosphaerium and Melosira. After two weeks nearly all Chlorococcales are absent, the phytoplankton consisting of Melosira and some other Diatoms only. Although Melosira does occur in fairly large numbers the total volume is seen to decrease owing to the small volume of the Diatoms compared with other algae. The bloom of the phytoplankton during the first week is much higher in the stocked ponds. Among Rotatoria Asplanchna is conspicuous, attaining high values in both stocked ponds during the third week. In the unstocked pond no 15 a bloom caused by Polyarthra was seen.

The numbers of Crustaceae are seen to follow those of phytoplankton with a lag of one week. Although these animals are eagerly devoured by the carp they are found in the stocked ponds in greater numbers. Benthic organisms are seen to increase untill the second or third week and are declining afterwards. In general numbers are higher in unstocked ponds notably the final values.

The percentual composition of the faeces shows that during the first weeks Crustaceae formed the principal food. As supply declines benthic fauna is increasing and the fish draws on this source accordingly, reducing their numbers. As the growth curve shows a decline during the last week a situation of overstocking did exist.

It is evident that here fish have accelerated metabolic feeding cycles as phytoplankton developed so readily. It seems that development of Crustaceae was more dictated by availability of food than by grazing and on the other hand development of benthic organisms more by grazing.

A comparison between the food of the carp and that of Lebistes is given in table XV. It follows that, when supply is plentiful, the 

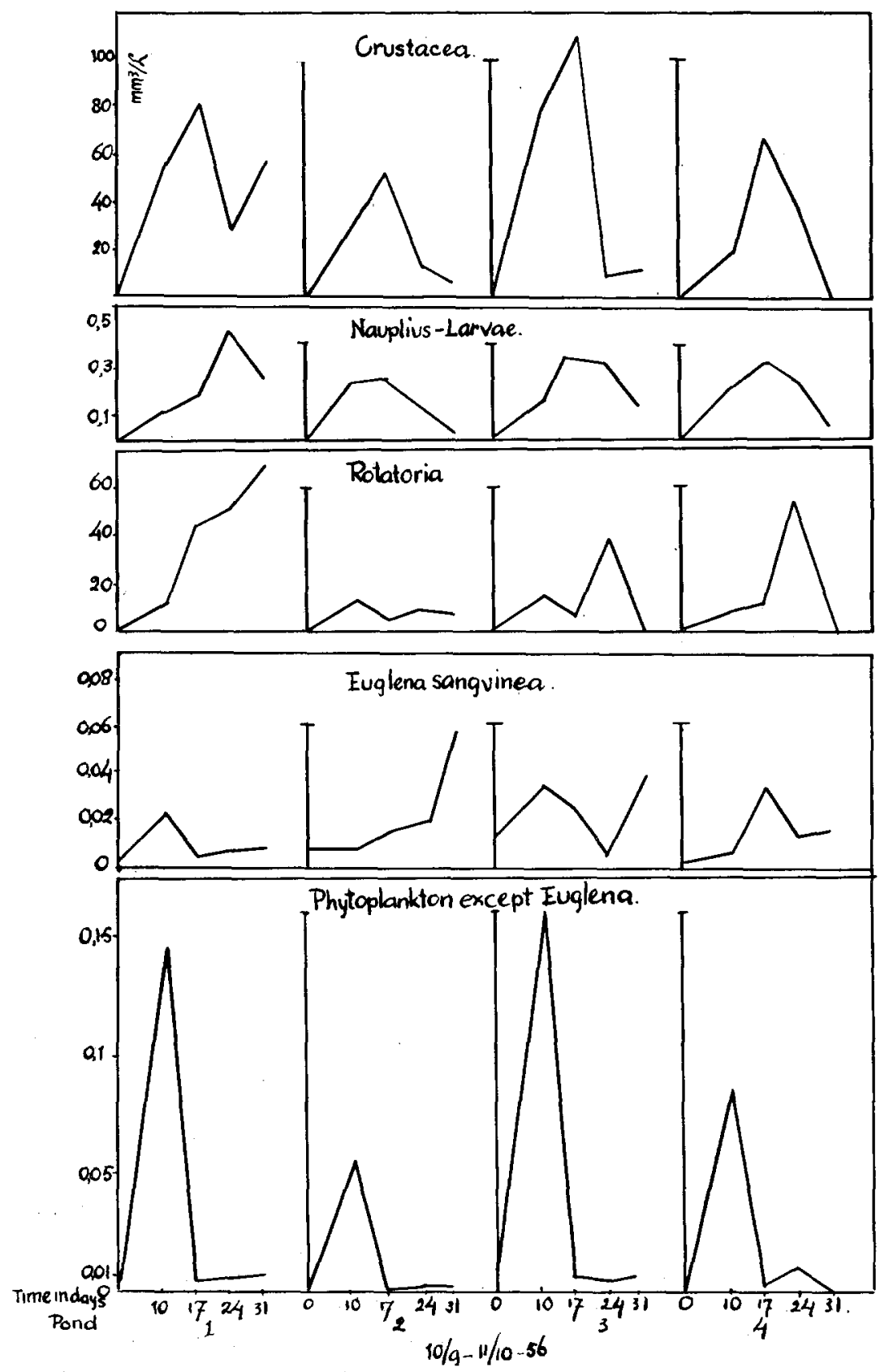

Fig. 8. Development of plankton in stocked (11 and 14) and unstocked (12 and 15) ponds in Bogor. 

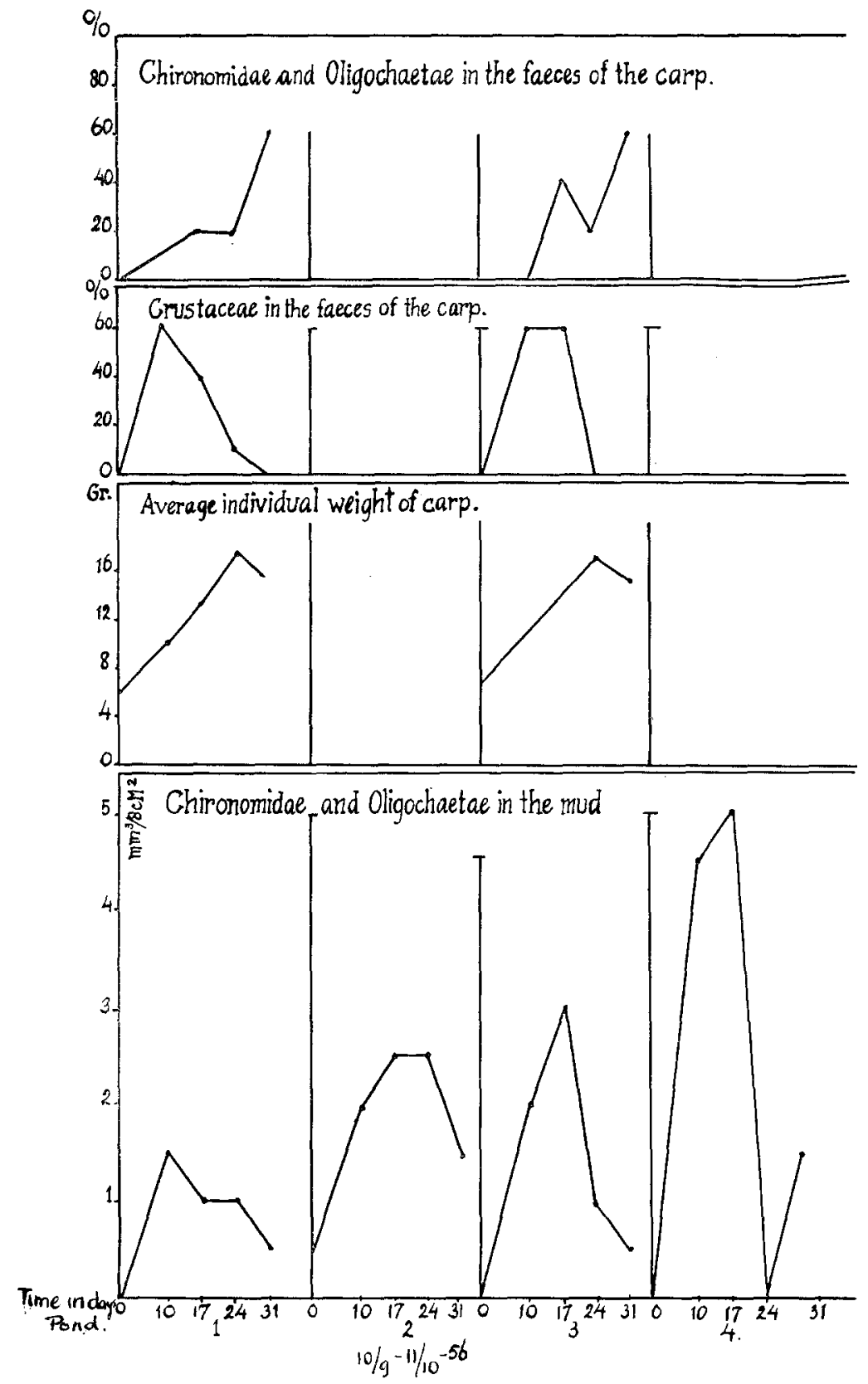

Fig. 9. Percentages of Crustaceae and Chironomidae in the faeces of the carp. Growth curves of carp from ponds 12 and 15. Development of organisms in the mud of stocked (11 and 15) and unstocked (12 and 15) ponds. 


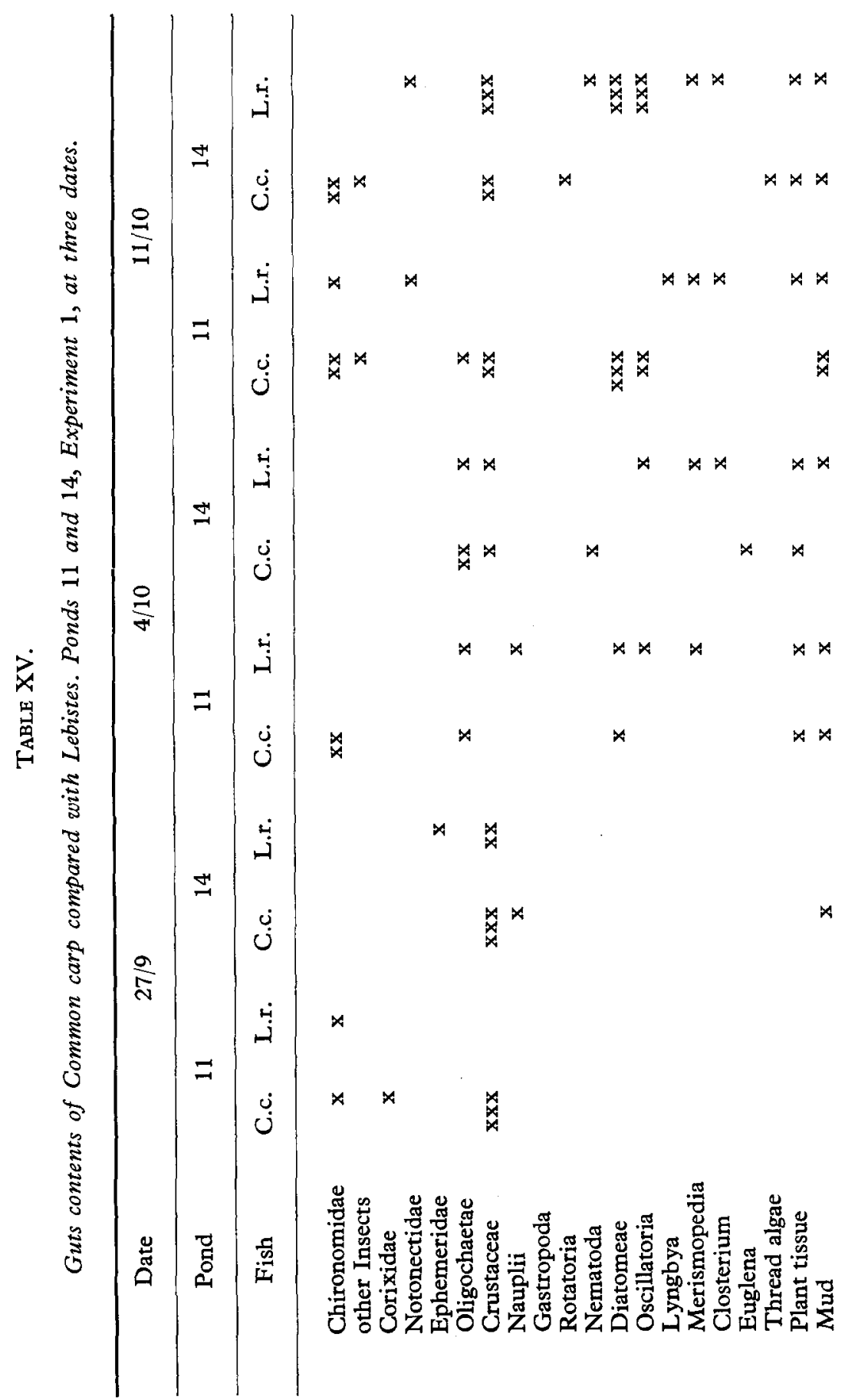


diets are nearly the same. However, when supply of Crustaceae and Chironomidae is failing Lebistes turns to plankton - Cyanophyceae, Rotatoria and Nauplii -, organisms too small for the carp. This fish will turn to detritus, snails and benthic algae in stead. (The samples taken $27 / 9$ and $4 / 10$ were faeces taken from live fish, the sample taken on $11 / 10$, at the end of the period contained entire guts contents, for this reason no comparison between the first two samples and the third one should be made, only between both fishes).

\section{Experiment 2.}

$15 / 10$ untill $15 / 11$. Ponds 11 and 14 unstocked, ponds 12 and 15 stocked with 800 carp, total weight resp. 272 and 288 gram.

Results: pond 12 cropped 620 carp, total weight 1063 gram increase 791 gram. pond 15 cropped 533 carp, total weight 853 gram - increase 565 gram.

Data pertaining to this experiment are given in tables XVI and XVII and figures 10 and 11 .

In this experiment a bloom of Euglena sanguinea made clear cut conclusions difficult. Already at the beginning of the period large numbers of Euglena were encountered. Probably these flagellates, having developed in the previous period, remain on the mud bottom after draining and are immediately present after the pond is refilled. When samples were taken during the second week a strong wind had accumulated the surface film in one corner of the pond and hardly any were sampled in the plankton. Some days after filling in all ponds a bloom of Pandorina was seen, however after a few days this alga disappeared. During the following weeks the phytoplankton was dominated by Diatomeae, notably Melosira and Navicula. The only reliable difference between stocked and unstocked ponds was that no. 12 contained more Diatomeae than all others, however a similar difference was not found in the other stocked one, no. 15. However in the nannoplankton of this pond large numbers of Richteriella were found 17 days after filling.

This phenomenon does not show in the figures owing to the small volume of the organisms concerned. Both Rotatoria and Crustaceae show a distinct maximum in the stocked ponds after resp. 10 and 17 days. It might be assumed that development of phytoplankton has been larger here, but that the algae were immediately consumed by the zooplankton.

No difference between numbers of Chironomidae and Oligochaetae in the mud of stocked and unstocked ponds could be ascertained here, but these animals were also found to be less important elements of food in the guts of the carp. 


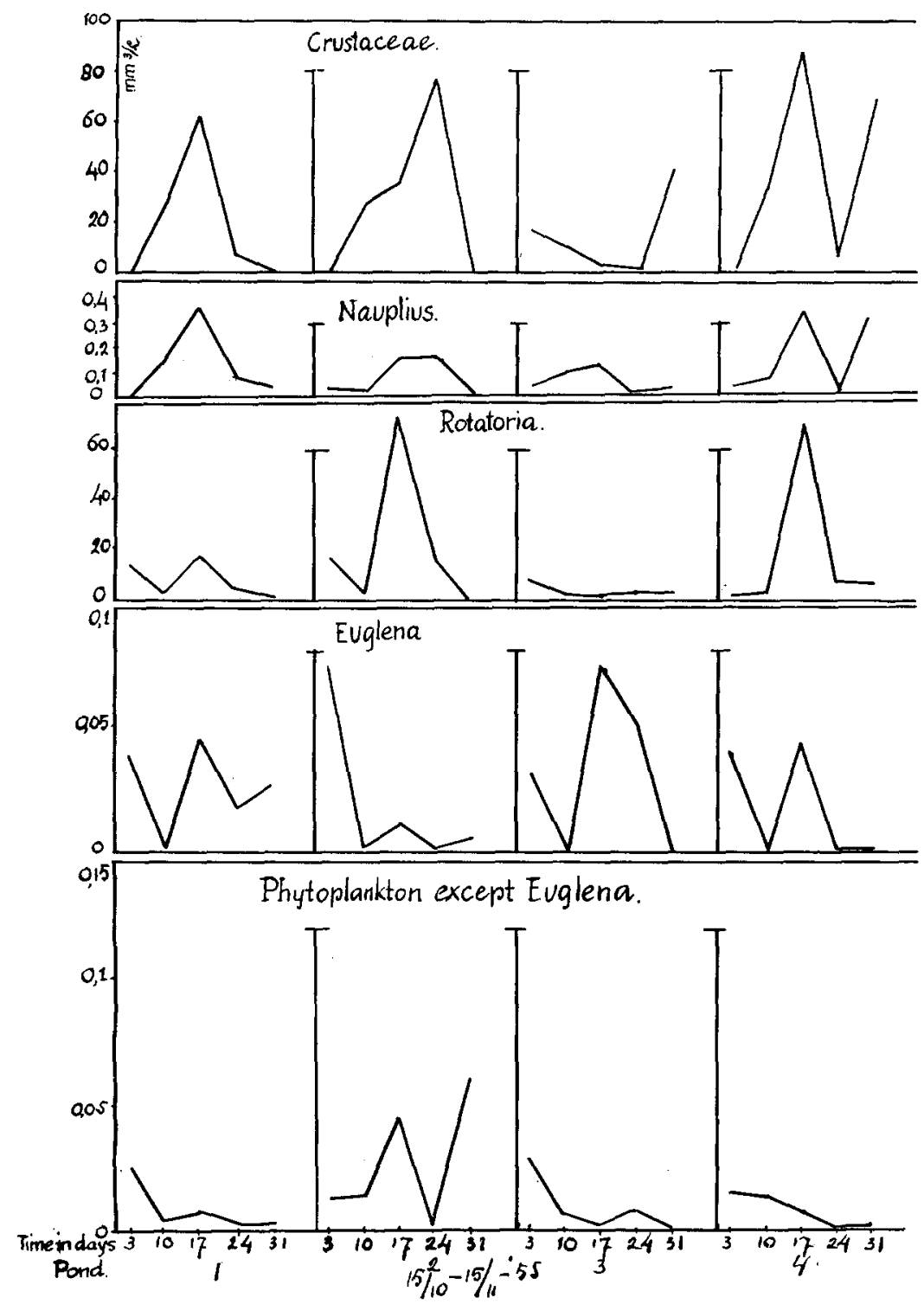

Fig. 10. As Fig. 8. Second experiment. Ponds 12 and 15 stocked, ponds 11 and 14 unstocked. 


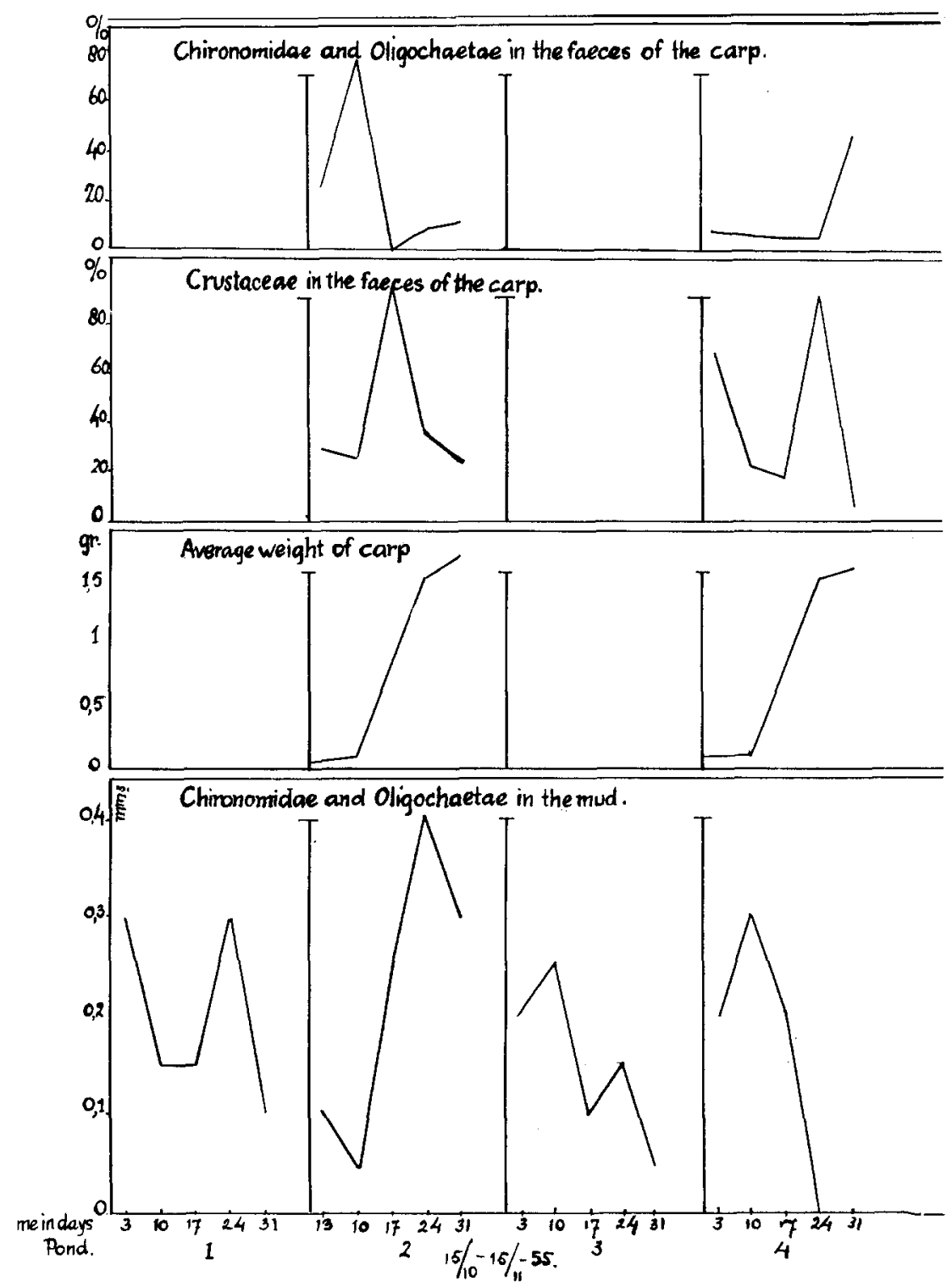

Fig. 11. As Fig. 9. Second experiment. Ponds 12 and 15 stocked, ponds 11 and 14 unstocked. 
Only in pond 12 during the second and in pond 15 during the last week a fairly large number of these animals was encountered in the guts and their number in the mud was found to decrease accordingly.

A survey of the analysis of faeces of live carp is given in table XVI. In confirmation of earlier findings it was found that these small fishes used Rotatoria as additional food and that in certain cases hard, unidentifiable seeds of higher plants (grasses?) formed a large fraction of the contents.

If follows from a comparison between the guts contents of carp and Lebistes (table XVII) that in this case too the main food is usually the same but that differences may occur in the additional food. These sources are mainly drawn upon when the supply of Crustaceae is low. Competition for Chironomidae did not seem to be so severe in this case.

The stocking rate in this experiment was calculated so as to make the product of the number stocked multiplied with the average weight per carp raised to the power $2 / 3$ about aqual to a similar value used in experiment 1 .

This calculation is based on the fact - well known in animal physiology - that the amount of food needed for maintenance of the body of an animal is proportional to the surface of the animal, which value may be taken to be proportional to the weight derived to the power 2/3. The total amount of maintenance food for all carp in the pond can be estimated in this way. (vide VAAS-VAN OvEN, Third Fisheries Training Centre F.A.O./Indon, Governm. Bogor 1955 to be published by F.A.O.)

The above mentioned values were: $800 \times 0,35^{2 / 3}=400$ for Experiment 2 and $120 \times 6,4^{2 / 3}=420$ for Experiment 1 .

As the amounts of maintenance food needed must be theoretically the same, the ponds should have yielded similar amounts of fishflesh, provided development of natural food had also been the same. It is seen that the yields differed to a marked extent and it follows from a comparison between the various growth curves (figure 11) that this time the ponds were not overstocked.

It might be assumed for this reason that the small carp used here did not yet fully utilize the available food, notably in the beginning of the period, with the result that a fraction is not utilized at all or eaten by other organisms. In this way the entire metabolic rate of processes operating in the pond is slowed down and development of food during the period was lower. By the time the carp were able to use the food to full extent, other organisms have already incorporated too much minerals and no bloom of phytoplankton took place, individual growth slowed down. The ponds must be considered to 


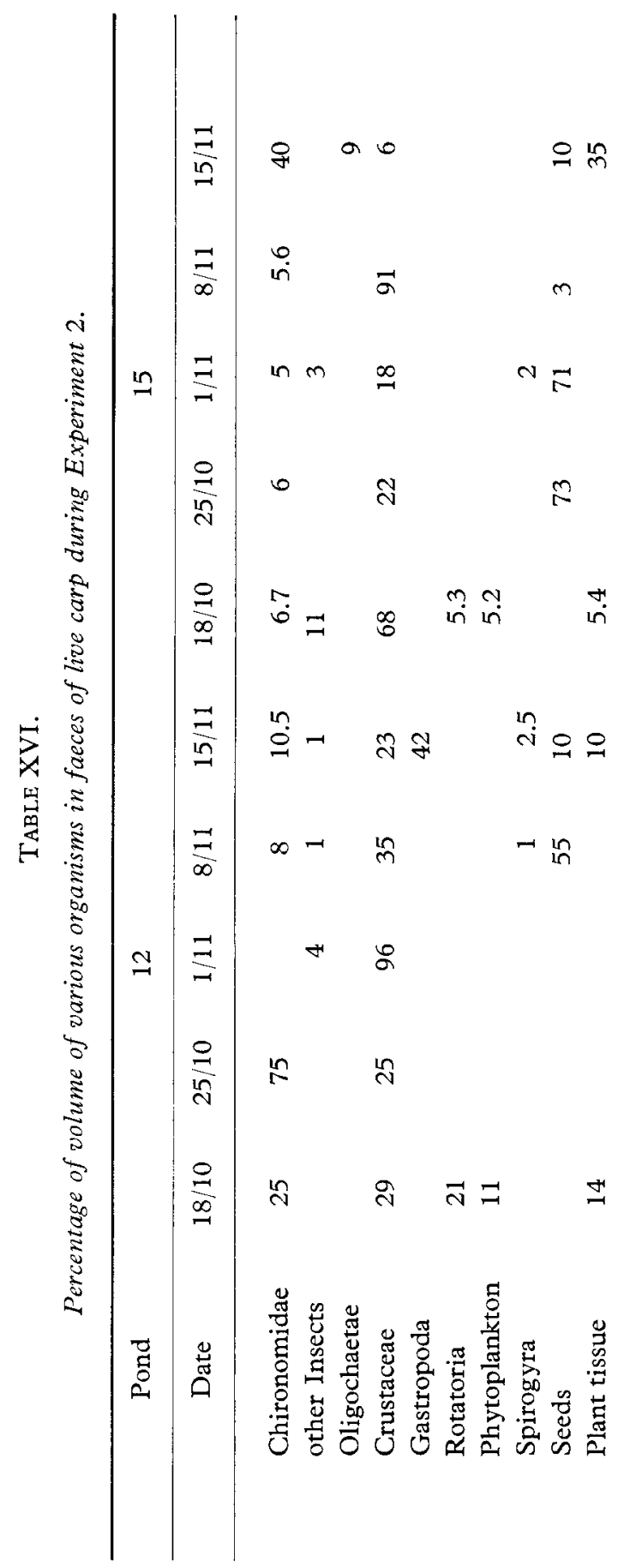




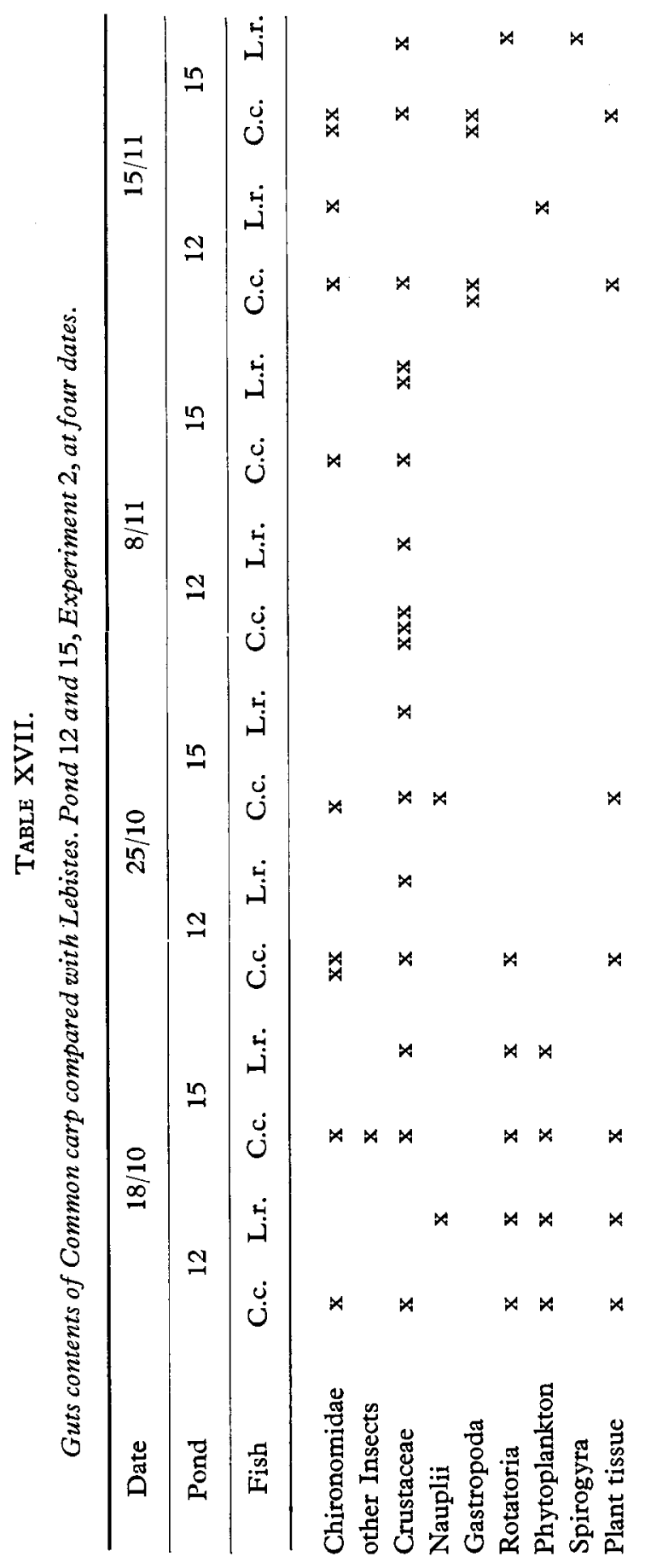


be understocked in this case. In an article by the second author (VAAS- VAN OvEN, in the press) to be published in the near future by the Indo-Pacific Fisheries Council, the relationships between stocking rate and development of natural food in carp ponds is treated. More evidence will be found there that the supply, utilization and incorporation of minerals act as limiting factor of fish production.

\section{Experiment 3.}

$16 / 11$ untill 14/12. Ponds 12 and 15 unstocked, ponds 11 and 14 stocked with 250 carp, total weight resp 260 and 270 gram.

Results: pond 11 cropped 125 carp, total weight 1165 gram increase 915 gram. pond 14 cropped 212 carp, total weight 980 gram - increase 710 gram.

Data pertaining to this experiment are given in table XVIII and figures 12 and 13.

In this experiment Euglena sanguinea occurred in increasing numbers throughout ponds 12,14 and 15. Phytoplankton consisted throughout the experiment of Diatomeae, mainly of Melosira and Navicula. As in both previous experiments these Diatomeae showed a better development in the stocked ponds.

A striking difference between the stocked and unstocked ponds in this experiment was a marked outburst of Crustaceae after two weeks in the unstocked ponds, to be replaced by Rotatoria one week later, whereas in the stocked ponds the number of Crustaceae was rather low in the beginning but increased towards the end. The number of Nauplii was seen to increase too and no bloom of Rotatoria did occur. Numbers of Chironomidae and Oligochaetae were distinctly higher in the unstocked ponds.

In accordance with supply the percentage of Crustaceae encountered in the faeces was seen to increase throughout and the percentage of Chironomidae was found to decline.

In pond no 11 heavy losses took place and the remaining carp had the opportunity to grow on. Losses were much lower in pond 14, but as the fish did not grow at the end and actually decreased in weight, total yield at the end was much lower.

Although it might be expected that the amount of maintenance food needed by the carp was lower in this case than in both previous experiments $\left(250 \times 1^{2 / 3}=250\right)-$ still it must be concluded that both ponds were overstocked on the strength of the evidence offered by the growth curves.

Probably the heavy outburst of Euglena, an organism not offering much food to various other biota owing to its hardy cysts, exerted an unfavourable influence on total development of food in the ponds. 


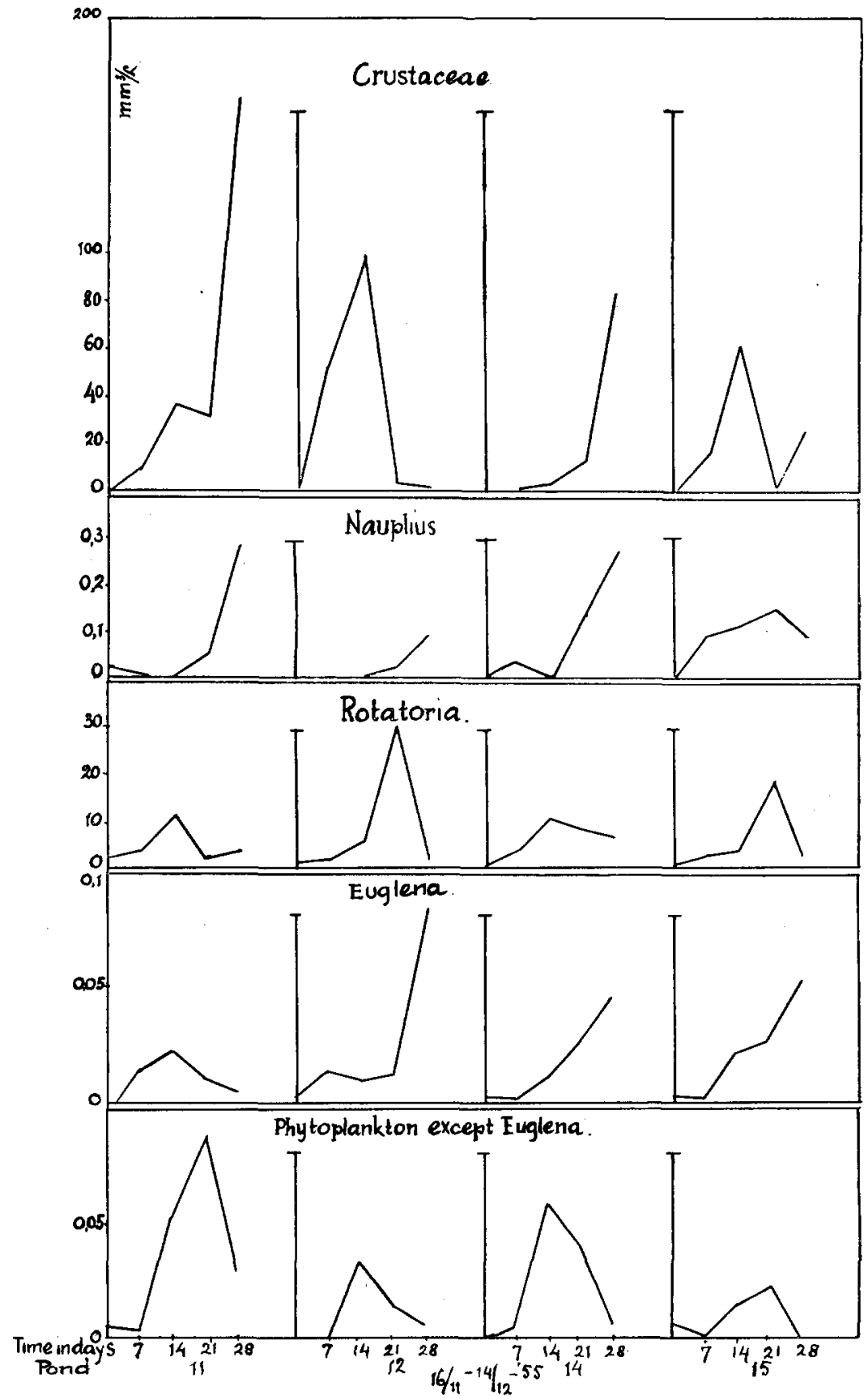

Fig. 12. As Fig .8. Third experiment. Ponds 11 and 14 stocked, ponds 12 and 15 unstocked. 

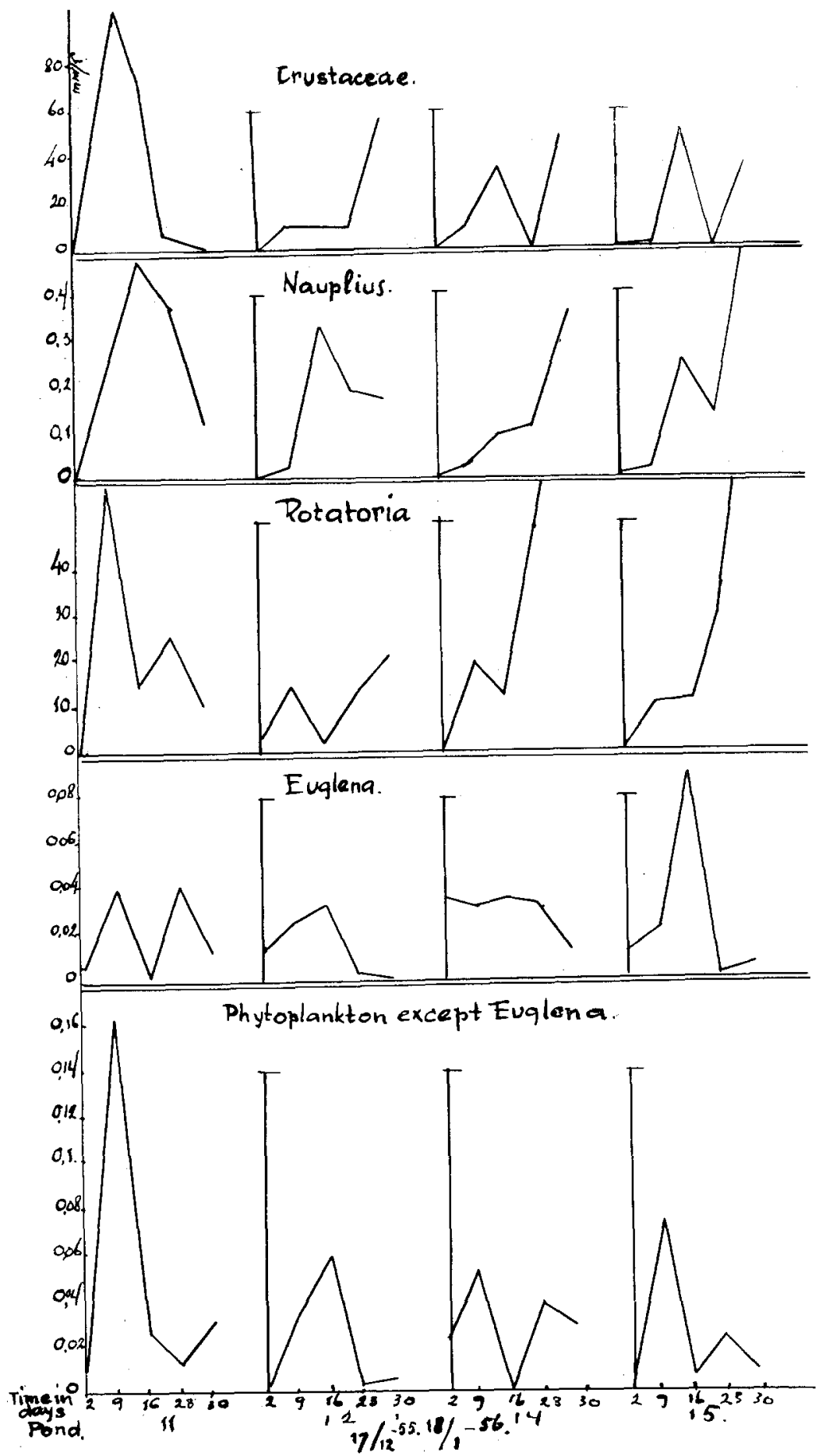

Fig. 13. As Fig. 9. Third experiment. Ponds 11 and 14 stocked, ponds 12 and 15 unstocked.

353 
The above mentioned difference between the stocked and unstocked ponds observed in this experiment might be explained in the following way. In the beginning of the period, when Euglena was not yet plentifully developed and other phytoplankters were frequent, conditions were favourable for Crustaceae. In the stocked ponds their number was kept rather low by constant grazing of the numerous carp. The metabolism of these fish, accelerating food cycles in the pond, kept conditions favourable for Crustaceae. However in the unstocked ponds a situation of overpopulation of Crustaceae gradually developed. The amount of phytoplankton - with the exception of Euglena - decreased and many Crustaceae died. On the dead bodies a large bacterial flora quickly developed, eaten themselves by Rotatoria.

Although Chironomidae and Oligochaetae did not occupy a prominent position in the diet, the number of carp was sufficiently high to decrease their numbers in the bottom of the pond. As in the previous experiment seeds were taken but not to such an extent. Comparison between the food of Cyprinus and Lebistes once more shows that the main food is practically similar but differences do occur in the various additional components. (table XVIII).

\section{Experiment 4.}

20/12 untill 17/1. Ponds 11 and 14 unstocked, ponds 12 and 15 stocked with 1500 carp, total weight 290 gram. Results: pond 12 cropped 956 carp, total weight 750 gram. - increase 460 gram. pond 15 cropped 960 carp, total weight 633.5 gram - increase 313.5 gram.

Data pertaining to this experiment are given in table XIX and figures 14 and 15.

The extremely high value for phytoplankton in 12 after the first week is caused by an outburst of Eudorina, immediately followed by Rotatoria and Crustaceae.

In both stocked ponds the usual bloom of Melosira was found in net- and nannoplankton, but owing to the slight volume of the cells the figures do not show this to advantage.

The fact that there is great similarity between both Crustaceae and Rotatoria in the unstocked pond 14 and the stocked no. 15 goes to show that factors other than those associated with the stocking rate have been active in this case.

Numbers of Chironomidae and Oligochaetae are distinctly lower in the stocked ponds.

In this experiment heavy losses created a situation of understocking ,as witnessed by the low yields and the constantly rising growth curves. Although Crustaceae dominated the food of the carp to a 


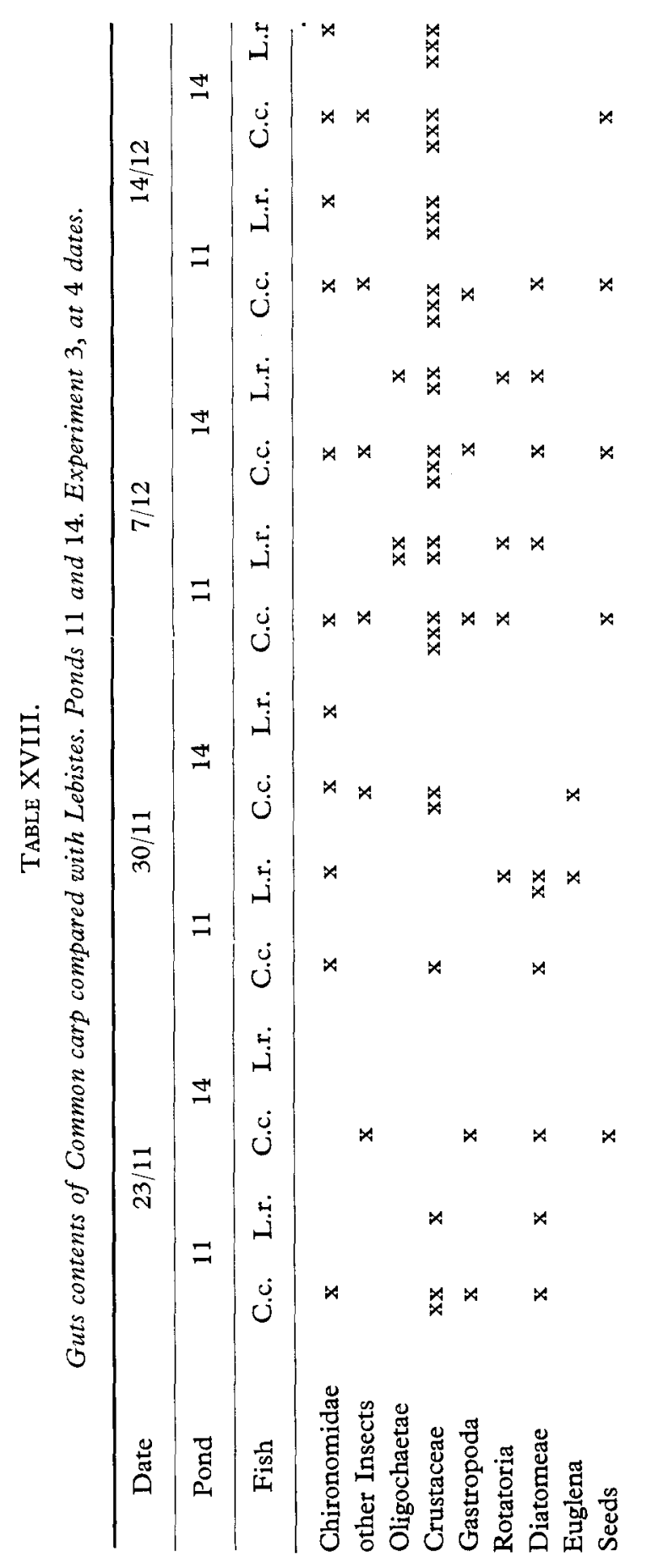




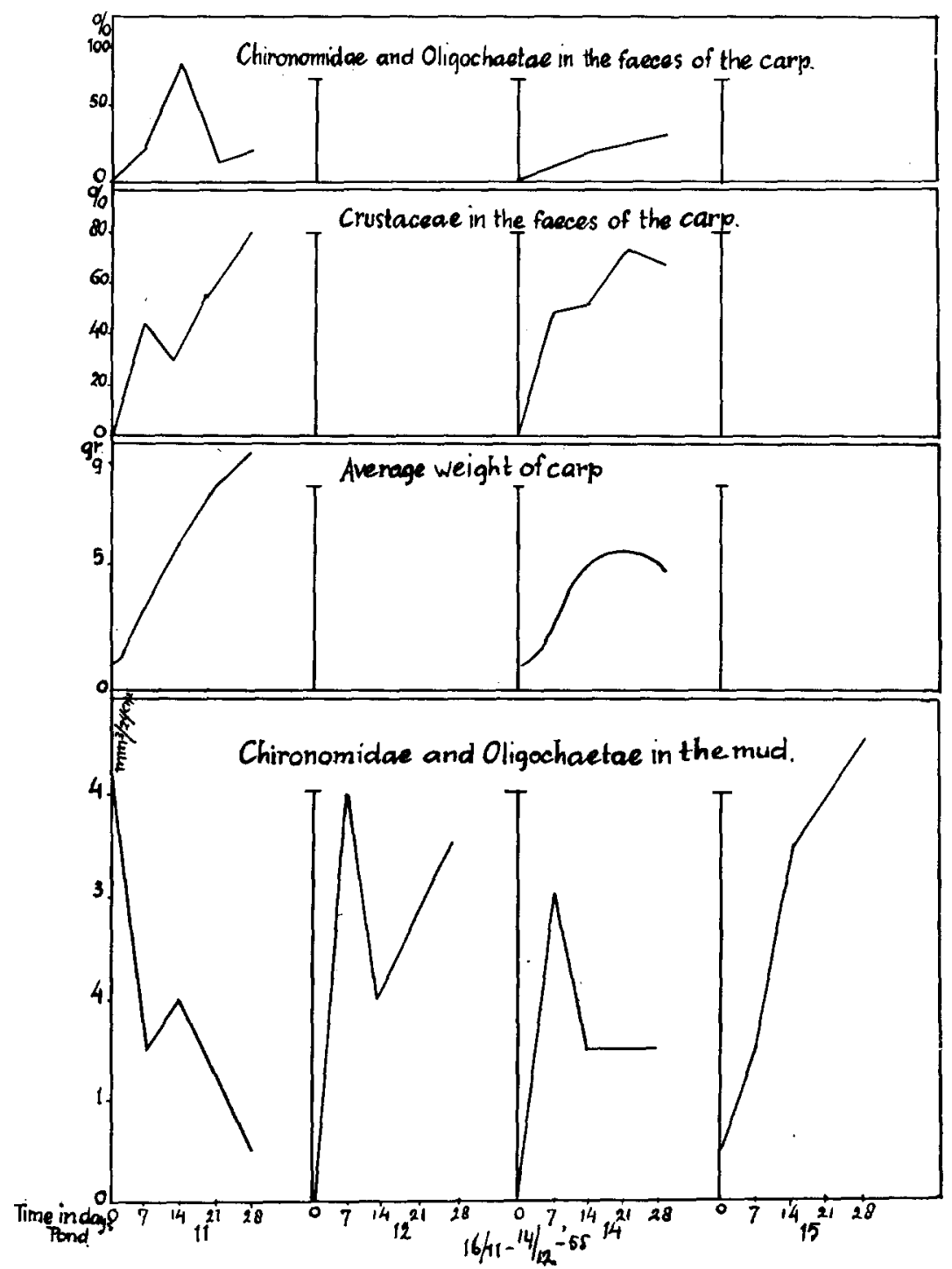

Fig. 14. As Fig. 8. Fourth experiment. Ponds 12 and 15 stocked, ponds 11 and 14 unstocked. 


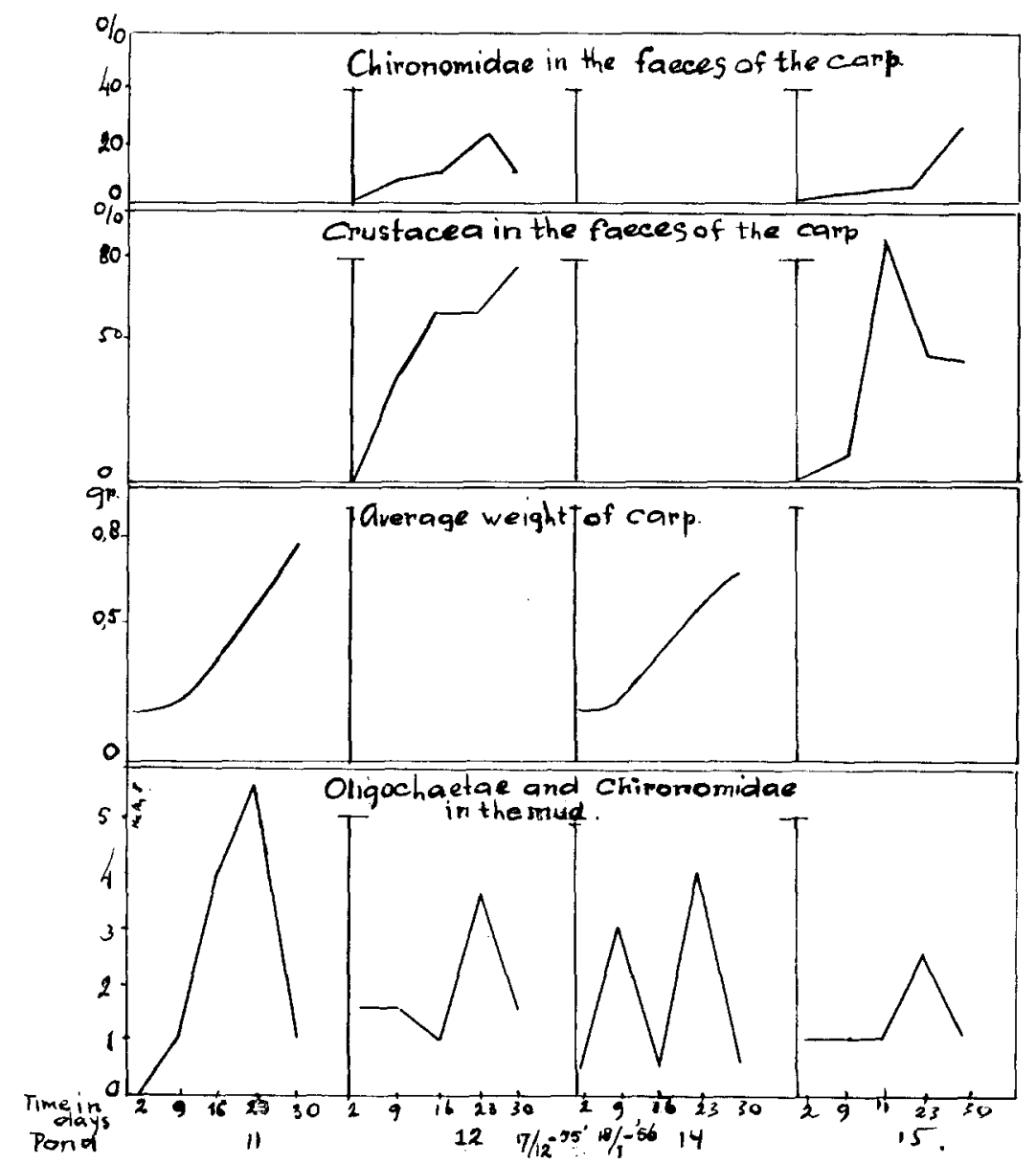

Fig. 15. As Fig. 9, Fourth experiment. Ponds 12 and 15 stocked, ponds 11 and 14 unstocked. 
marked extent, no influence of grazing can be found comparing ponds 14 and 15 .

As was already stated earlier disturbing influences made results of this experiment unreliable, and hardly any conclusions can be drawn. However, as this experiment was designed to be comparable to the others we do not wish to delete the results.

A comparison between common carp and Lebistes confirms previous findings (table XIX).

\section{GENERAL CONCLUSIONS}

As in all investigations concerning pond-biota (WIRSZUBSKI 1953, SWINGLE 1947, TANG 1954, VAAS - VAN Oven, in press and many older authors) great differences between development of plankton in comparable ponds were encountered. Development evidently depends on a multitude of different factors. For this reason we shall use in the following discussions data either comparable for nearly all experiments and for all ponds or for two parrallelles within a single experiment. We feel that conclusions about general processes in the ponds might be drawn from the first and about the influence of the stocked carp from the second category of data.

As the water supply of the ponds does contain a good deal of organic silt but hardly any organisms, plankton will be hardly present in the beginning. Generally speaking an outburst of phytoplankton will be seen during the first weeks, followed by Rotatoria and Crustaceae.

During the first week Protococcales are most important constituents of the plankton, however, disappearing during the following weeks, they are replaced by Diatoms, mainly the genera Melosira and Navicula. Towards the end of the experiment- after one monthall plankton declines in number, barring certain exceptions. Similarily benthic organisms usually show a maximal development during the second or third week of the period.

We should like to explain these phenomena by developing the following general picture of metabolic relationships and food-cycles in the pond. Immediately after filling with water organic substances on the bottom are being mineralized by bacteria and detritus-feeding animals on the bottom.

Phytoplankton subsists on the minerals released by the above mentioned processes of mineralization. Zooplankton follows the phytoplankton. The detritus-feeders grow quickly and moreover new Chironomid-larvae will develop as a result of oviposition.

During the entire period minerals are being incorporated, either by aminals leaving the pond - those insect larvae reaching maturity 


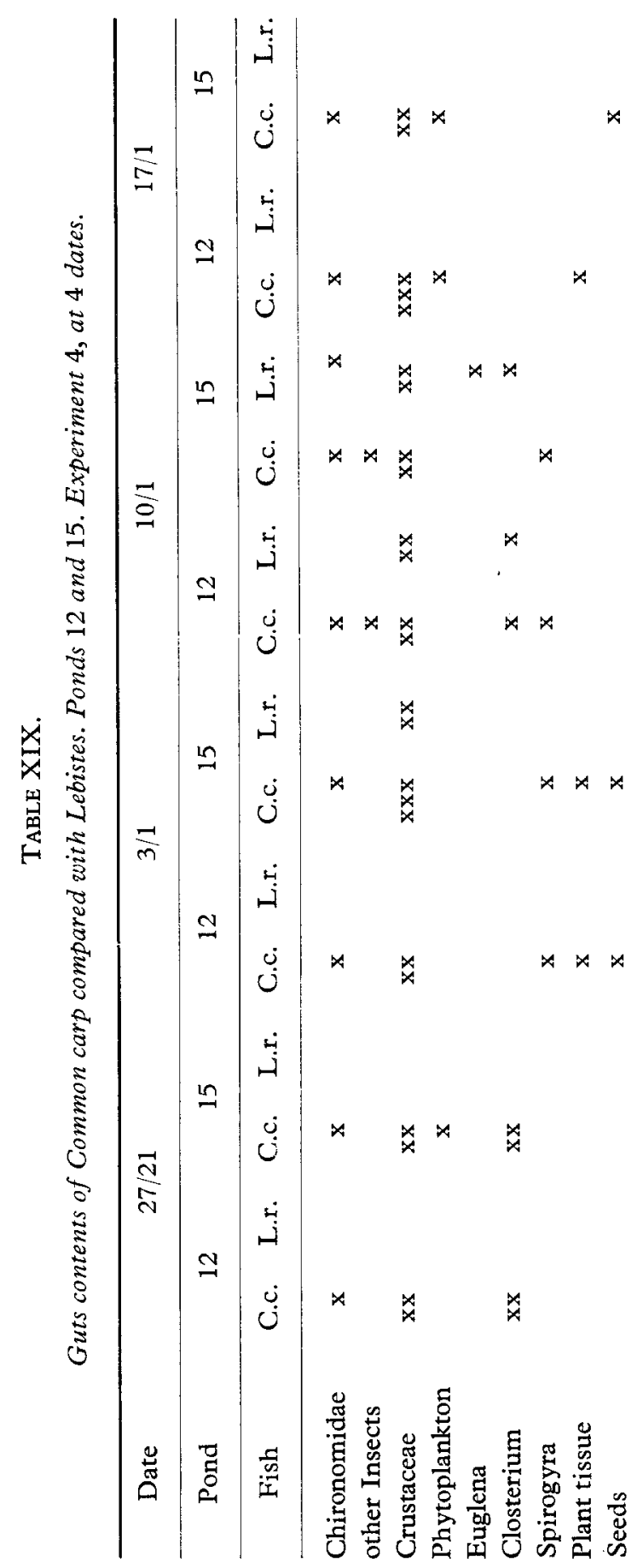


and flying away -, in carp lost to predating birds, or in organisms not eaten by other pond- biota-, or in a succession of animals with the carp itself at the end.

Benthic fauna is eaten in increasing numbers by animals growing larger all the time. This process of grazing proceeds at a higher rate than the combined processes of growth and new supply by oviposition of Chironomidae and growth of aquatic worms. As a result of decreasing availability of minerals phytoplankton must decline.

According to Kosmarovsky (1952) Scenedesmus needs a higher concentration of phosphates than Diatomeae. SMITH \& SWINGLE (1939) report a favourable influence of inorganic fertilizer on the development of Protococcales but hardly any on Diatomeae. Reviewing his findings on the Diatomeae of the German Sunda Expedition HustedT (1938) says:,... insbesondere erscheint die für die Charakteristik der Gewässer wichtige Melosira granulata als eine an den fallenden N- bzw. P- Gehalt gebundene Form".

These statements seem to be in accordance with our observation that Protococcales were abundant in the first week of the period and Diatomeae - notably Melosira - later on.

Considering the influence of the carp we find that usually the development of phytoplankton - and consequently zooplankton too is encouraged. Even at the end of each period the numbers of phytoplankters found in the stocked ponds were higher than those in the unstocked ones, notably Melosira.

However benthic organisms are definitely reduced in number by the fish. The incorporation of minerals does not proceed at a higher rate in stocked ponds than in unstocked ones, although the carp is incorporating a good deal. In order to explain this it might be assumed that more bottom organisms, storing minerals, are eaten by the fish. In unstocked ponds many midge-larvae will be able to accomplish their metamorphosis and will leave the ecosystem bringing about a loss of minerals. Empty skins of pupae were several times encountered on the surface of unstocked ponds and in the stocked ponds hardly any were found.

The numbers of Crustaceae and Chironomidae encountered in the faeces and in the ponds shown in the figures $8-15$, enable us to carry out the following rough calculation.

The Crustaceae found in 1 litre form about 1:100,000 part of the total number present in the pond. If we multiply the number for Chironomidae with 2, obtaining the number for $16 \mathrm{~cm}^{2}$, this number will be about $16: 2000,000$ part of the total number on the bottom. As these fractions are about the same we arrive in this way at comparable figures for the numbers of both groups available as natural food for the carp. 
In this way an average figure of $37 \pm 6.54$ is found for Crustaceae and $3.5 \pm 0.42$ for Chironomidae.

Similarily the average percentages for all 34 cases found in the faeces are $44.5 \pm 4.7$ for Crustaceae and $20.8 \pm 3.5$ for Chironomidae.

As is shown in the figures $8-15$ the number of Crustaceae eaten depends on the number available but the number of Chironomidae eaten does not.

Pending further experimental evidence we wish to explain these relationships by assuming that the carp, taking in Crustaceae from the water in an easy way when supply is large, is less inclined to seek food on the bottom or along the shores. In our case the quantity of Crustaceae was still insufficient and intensive search for food on the bottom was the result. In experiments published elsewhere (VAAS VAN OVEN in the press) many cases were found where only Crustaceae were eaten when supply was large, although Chironomidae were available as well and where Chironomidae only formed a large percentage of the guts contents when hardly any Crustaceae were present.

\section{SECTION 3.}

RELATION BETWEEN GUTS CONTENTS AND AVAILABILITY OF FOOD IN VARIOUS OTHER PONDS.

At this stage we wish to show the results obtained from a study of the intestinal contents of carp of various sizes taken from 2 ponds of the Government Hatchery at Sukabumi and from 4 ponds near Palembang, where pond biota were sampled simultaneously with the guts, in order to compare the results obtained in Bogor with conditions elsewhere in Indonesia. The hatchery at Sukabumi is situated about $60 \mathrm{~km}$ South-East of Bogor, at an altitude of $600 \mathrm{~m}$. In the beginning of August, towards the end of the dry season, 30 common carp were collected at intervals of 4 hours, during 24 hours, from pond no 11 and pond no 18 , both measuring $504 \mathrm{~m}^{2}$, and both about $70 \mathrm{~cm}$ deep. No 18 never received any manure, no 11 was given horse manure at a rate of $2000 \mathrm{~kg} /$ ha during two previous experiments, but none during the growth period when the samples were taken. The hatchery is situated on fertile young vulcanic soil, the water of both ponds showed a $\mathrm{pH}$ of 7.8 - -8.0 in the morning and methylorange alkalinity of 1.1-1.3. The bottom of no 18 was covered with Spirogyra, while some Azolla pinnata was floating on the surface. In no 11 a heavy growth of Hydrilla was noted, with Azolla covering about half the surface.

Table XX gives some idea of the production of both ponds, when 
stocked with fry or fingerlings of the common carp, together with a few large carp, as is the usual practice in West Java. The data are the results of previous growth periods.

TABLE XX.

Productivity of ponds 11 and 18, Sukabumi.

\begin{tabular}{lllrr}
\hline Stocking rate & $\begin{array}{c}\text { Total } \\
\text { weight } \\
\text { kg }\end{array}$ & \multicolumn{2}{c}{$\begin{array}{l}\text { Period } \\
\text { in days }\end{array}$} & \multicolumn{2}{c}{ Yield in kg } \\
& 11 & & & \\
\hline 1) 2500 fry of $2 \mathrm{~cm}+7$ carp & 1.5 & 25 & 8,477 & 8,474 \\
2) 100 fingerl. $5 \mathrm{~cm}+6$ carp & 1.2 & 36 & 6,698 & 7,445 \\
3) 2500 fry of $2 \mathrm{~cm}+7$ carp & 1.5 & 34 & 10,860 & 7,300 \\
4) 75 carp of $7 \mathrm{~cm}+3$ carp & 1.0 & 36 & 11,500 & 10,000 \\
5) 1000 fry of $3 \mathrm{~cm}+6$ carp & 1.0 & 26 & 9,030 & 14,500 \\
6) 2000 fry of $2 \mathrm{~cm}+5$ carp & 0.75 & 26 & 10,853 & 6,650
\end{tabular}

For the experiment both ponds were stocked on July 17th 1954, with 100 fingerlings of 6 gram each - about $5 \frac{1}{2} \mathrm{~cm} \mathrm{-.} \mathrm{On} \mathrm{August}$ $6 / 7 t h, 5$ fish were taken out of both ponds, at 4-hours intervals during 24 hours. These carp were measured, weighed, immediately cut open and the intestinal tracts preserved with $4 \%$ formalin. The 30 carp from no. 18 ranged from 10.5 to $14.5 \mathrm{~cm}$ in total length and from 24 to 59 grams in weight. Those from no. 11 from 10 to $13.7 \mathrm{~cm}$ in length and from 22 to 27 gram weight. During sampling the temperature of the air fluctuated between $20.8^{\circ}$ at 4 a.m. and 27.50 at noon, and the temperature of the water - measured at the surface - from $24^{\circ}$ at 4 a.m. to $29.5^{\circ}$ at 4 p.m.

Samples of net plankton were taken as well as nannoplankton samples, the latter with the Iodine-sedimentation method. Samples of Hydrilla, Spirogyra and grasses along the banks were washed in large white dishes. All organisms were picked off, studied and counted under a binocular microscope. Identification was undertaken as far as possible and practical for a study requiring a large number of samples.

In 2 cases the guts were damaged, in 5 cases they were found empty, so that the total number studied amounts to 26 from no. 11 plus 27 from no 18, making an aggregate of 53 carp.

Guts contents were studied in the way described in the previous sections, but in this case each quarter of the intestine was studied separately. In this way a better insight into digestibility is obtained.

The availability of natural food in open water, as revealed by a study of net and nannoplankton samples from both ponds, is shown in Table XXI. As only a limited number of samples was available organisms were not counted. 
TABLE XXI

Net plankton and nannoplankton in ponds 11 and 18 at Sukabumi.

\begin{tabular}{|c|c|c|}
\hline Organisms & Ponds 11 & Ponds 18 \\
\hline Diaphanosoma & $\mathrm{xx}$ & $\mathrm{xx}$ \\
\hline Cyclopidae & $x x$ & $\mathrm{xxx}$ \\
\hline Nauplii & $\mathrm{xxx}$ & $\mathbf{x x x}$ \\
\hline Filinia & $\mathbf{x x}$ & $\mathbf{x x}$ \\
\hline Brachionus & $\mathrm{x}$ & $x x$ \\
\hline Arcella & $\mathrm{x}$ & $\mathrm{x}$ \\
\hline Vorticella & $x x$ & $\mathbf{x}$ \\
\hline Synedra & $\mathrm{xxx}$ & $\mathrm{xxx}$ \\
\hline Surirella & $\mathbf{x x}$ & $\mathbf{x}$ \\
\hline Other Diatoms & $\mathrm{x}$ & $x x$ \\
\hline Oedogonium & $\mathrm{x}$ & $\mathrm{xxx}$ \\
\hline Raphidium & $\mathbf{x x}$ & $x x$ \\
\hline Cosmarium & $\mathrm{x}$ & $x$ \\
\hline Staurastrum & $\mathrm{x}$ & \\
\hline Pediastrum & $\mathrm{x}$ & $\mathrm{x}$ \\
\hline Richteriella & $\mathrm{x}$ & $\mathrm{x}$ \\
\hline Pandorina & $\mathrm{x}$ & $\mathrm{x}$ \\
\hline Chlamydomonas & $\mathrm{x}$ & $\mathrm{x}$ \\
\hline Euglena & $\mathbf{x}$ & $\mathrm{x}$ \\
\hline
\end{tabular}

TABLE XXII.

Organisms in the mud of ponds 11 and 18 Sukabumi.

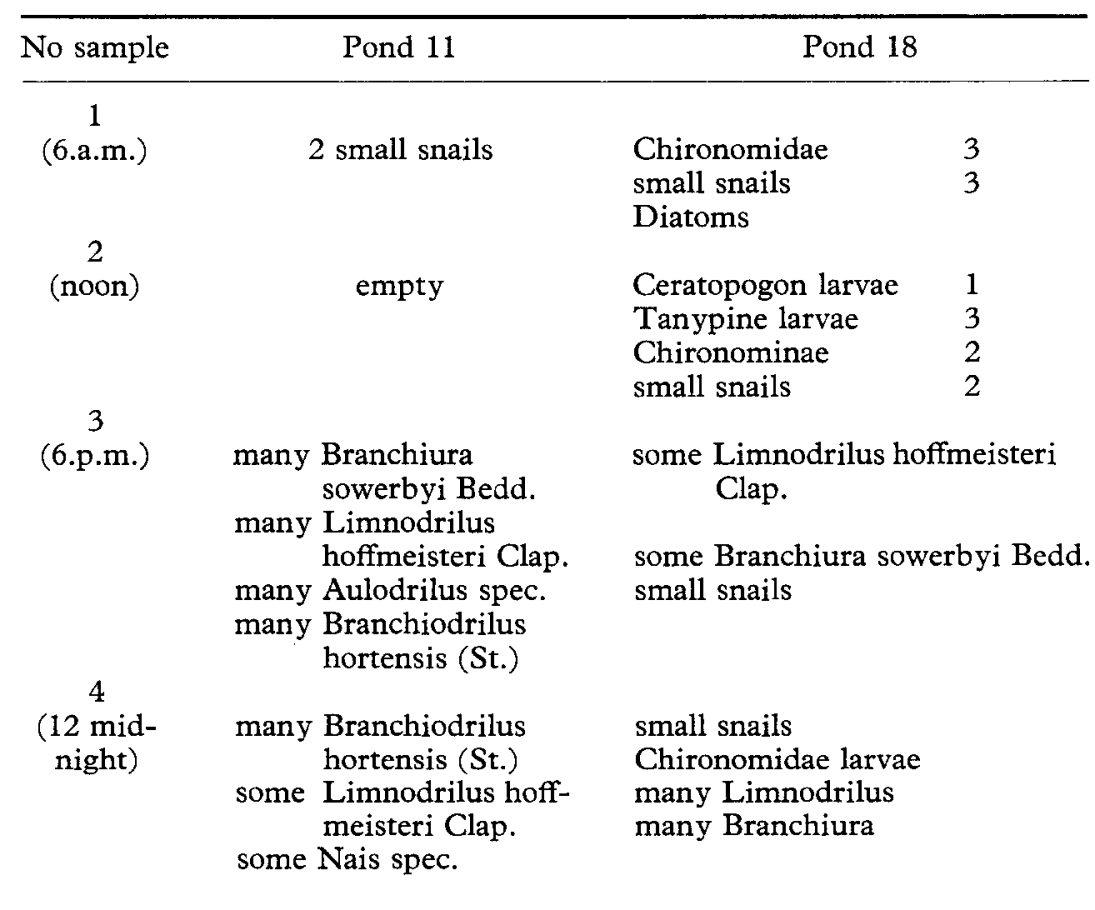


As was to be expected hardly any difference between the two ponds could be found, both showing a fairly rich plankton dominated by Diatomeae and Crustaceae, with slightly more Oedogonium in 18 than in 11 .

From pond 11 two samples of the aquatic vegetation were taken. In 10.6 gram air-dried Hydrilla the following organisms were found:

96 Tanytarsus larvae

3 Chironomidae larvae

1 unidentifiable Tendipedidae.

In the same sample we counted 381 Oligochaetae. 66 of these worms were specified as follows:

Dero spec.

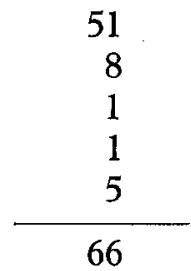

On 4.6 gram air-dried Spirogyra were found:

Caenis larvae, $8 \mathrm{~mm}$

\begin{tabular}{l}
1 \\
1 \\
1 \\
2 \\
\hline 5
\end{tabular}

The Hydrilla was densely overgrown with small Diatomeae, young threads of Spirogyra and Oedogonium. Between the periphyton many Pediastrum and Cosmarium were found and some Cypris spec. (Ostracoda).

On the slimy, slippery threads of Spirogyra, mixed with some Hydrodiction, periphyton was very rare.

In pond 18, only Spirogyra was encountered and the number of organisms found among the threads was far lower. Only 1 Ceratopogon larva (Bezzia-type) was found, together with 13 Oligochaetae:

Dero zeylanica Steph. $\quad 5$

Dero limosa Leidy 1

Nais paraquayensis $M$. 3

Nais communis Piq. 1

Nais communis var. caeca Steph. 1

Unident. 
The bottom samples consisted of approximately $330 \mathrm{cc}$ brown, lateritic mud with some sand and small pebbles. In those from pond 11 many vegetable remains were found. The entire samples were studied under the binocular microscope with the results shown in Table XXII.

The data seem to indicate that Oligochaetae bury deeper into the mud at day time and protrude further into the water during the night when the concentration of oxygen is lower.

The supply of natural food for the common carp in both ponds can be summarized as follows. (Table XXIII).

TABLE XXIII.

Supply of natural food in pond 11 and 18 Sukabumi.

\begin{tabular}{|c|c|c|c|c|}
\hline & Pond 11 & & Pond 18 & \\
\hline Open water & Crustaceae & $\mathrm{xx}$ & $\begin{array}{l}\text { Crustaceae } \\
\text { (Cyclop.) }\end{array}$ & $\mathrm{xxx}$ \\
\hline $\begin{array}{l}\text { Vegetation } \\
\text { open water }\end{array}$ & $\begin{array}{l}\text { Hydrilla and } \\
\text { Spirogyra with }\end{array}$ & & $\begin{array}{l}\text { Spirogyra with } \\
\text { Oedogonium and }\end{array}$ & \\
\hline and along the & Oedogonium and & & Oligochaetae & $\mathrm{x}$ \\
\hline banks & $\begin{array}{l}\text { Chironomidae } \\
\text { Oligochaetae }\end{array}$ & $\begin{array}{l}x x x \\
x x x\end{array}$ & & \\
\hline & Insect larvae & $\mathrm{xx}$ & & \\
\hline & Ostracoda & $\mathbf{x}$ & & \\
\hline Bottom & Snails & $\mathrm{x}$ & Snails & $\mathrm{x}$ \\
\hline Fauna & Oligochaetae & $\mathrm{xx}$ & $\begin{array}{l}\text { Oligochaetae } \\
\text { Chironomidae }\end{array}$ & $\begin{array}{r}x x \\
x\end{array}$ \\
\hline $\begin{array}{l}\text { Bottom flora } \\
\text { Vegetable } \\
\text { detritus }\end{array}$ & $\begin{array}{l}\text { Vegetable } \\
\text { detritus }\end{array}$ & $\mathrm{xx}$ & Spirogyra & $\mathrm{xx}$ \\
\hline
\end{tabular}

The guts contents were studied by the methods described in the first section. Each quarter of the intestine was studied separately and the findings were combined later on. Not all of the $4 \times 53$ protocols can be published here. Some summaries and some instructive instances will have to suffice.

By studying the difference between each of the four quarters of the same intestinal tract it was found that sometimes marked discrepancies occurred between the guts contents of fully comparable carps feeding together in the same pond at the same time, as well as between the fractions of the same intestinal tract. We shall confine ourselves to the data given in Table XXIV, showing the results of the analysis of the guts contents of carp no 4 and no 5 from pond 11, taken at noon.

Consequently carp no 4 took about 7 times as many Chironomidae and about 4 times as many insects as no 5, but for Cyclopidae, 
TABLE XXIV.

Difference in guts contents of two similar carp, feeding together in pond 11, sampled at 12 hrs. 00.

(Figures show numbers of organism, unless volume in $\mathrm{mm}^{3}$ is indicated).

Pond 11. Carp No. 4. Length $11.5 \mathrm{~cm}$. weight $34 \mathrm{~g}$.

\begin{tabular}{lrrrrrc}
\hline & $1 / 4$ & $2 / 4$ & $3 / 4$ & $4 / 4$ & Total & Vol $\mathrm{mm}^{3}$ \\
\hline Chironomidae & 108 & 160 & 54 & 108 & 430 & 130 \\
Ceratopogonidae & 4 & - & 6 & - & 10 & 1 \\
Other Insects & 12 & 25 & 6 & 13 & 56 & 56 \\
Oligochaetae & 28 & 30 & 2 & 9 & 69 & 7 \\
Cyclopidae & 24 & 40 & 14 & 63 & 141 & 14 \\
Cladocera & 8 & 5 & 6 & 9 & 28 & 1.5 \\
Ostracoda & - & - & - & 9 & 9 & -13 \\
Thread Algae & 132 & 350 & 122 & 81 & 685 & 13 \\
Plant tissue & 3.5 & 3.5 & 3.5 & 3.5 & 15 & 15 \\
(in $\mathrm{mm}^{3}$ ) & & & & & Total volume & 237.5
\end{tabular}

Pond 11. Carp No. 5 Lenght $12.5 \mathrm{~cm}$. weight $40 \mathrm{~g}$.

\begin{tabular}{|c|c|c|c|c|c|c|}
\hline & $1 / 4$ & $2 / 4$ & $3 / 4$ & $4 / 4$ & Total & Vol mm $\mathrm{mm}^{4}$ \\
\hline Chironomidae & 6 & 7 & 4 & 42 & 59 & 18 \\
\hline Ceratopogonidae & 1 & - & - & - & - & - \\
\hline Other Insects & 1 & 2 & 12 & - & 15 & 15 \\
\hline Oligochaetae & 3 & 2 & 4 & 6 & 15 & 1.5 \\
\hline Cyclopidae & 99 & 280 & 332 & 438 & 1149 & 115 \\
\hline Cladocera & 30 & 160 & 132 & 150 & 480 & 24 \\
\hline Ostracoda & 59 & 358 & 342 & 252 & 1001 & 50 \\
\hline Thread Algae & 50 & 101 & - & 60 & 15 & 4 \\
\hline \multirow{2}{*}{$\begin{array}{l}\text { Plant tissue } \\
\text { (in } \mathrm{mm}^{3} \text { ) }\end{array}$} & 3.5 & 3.5 & 3.5 & 3.5 & 211 & 15 \\
\hline & & & & \multicolumn{2}{|c|}{ Total volum } & 242.5 \\
\hline
\end{tabular}

Cladocera and Ostracoda respectively the ratio amounted to 7 to 17 times and over 100 times less. Differences between individual quarters of the same guts appear with respect to Ostracoda and Oligochaetae in carp no 4 and with respect to Cladocera, Ostracoda and Thread Algae in carp no 5.

As in the previous experiment the common carp was found to be an opportunistic, polyphagous feeder, browsing in the mud on the bottom at one moment and - suddenly swimming away - perhaps at the next moment starting to feed voraciously on a swarm of Crustaceae encountered in the open water. $\left.{ }^{1}\right)$ This makes the use of large numbers of samples necessary, and for this reason sums of the contents of 10 carp were used in the first Section.

1) after many years of study WILLER sighed in $1924, \ldots$. . dass im einzelnen der Karpfen eigentlich in jeder Teichwirtschaft etwas anderes frisst." 


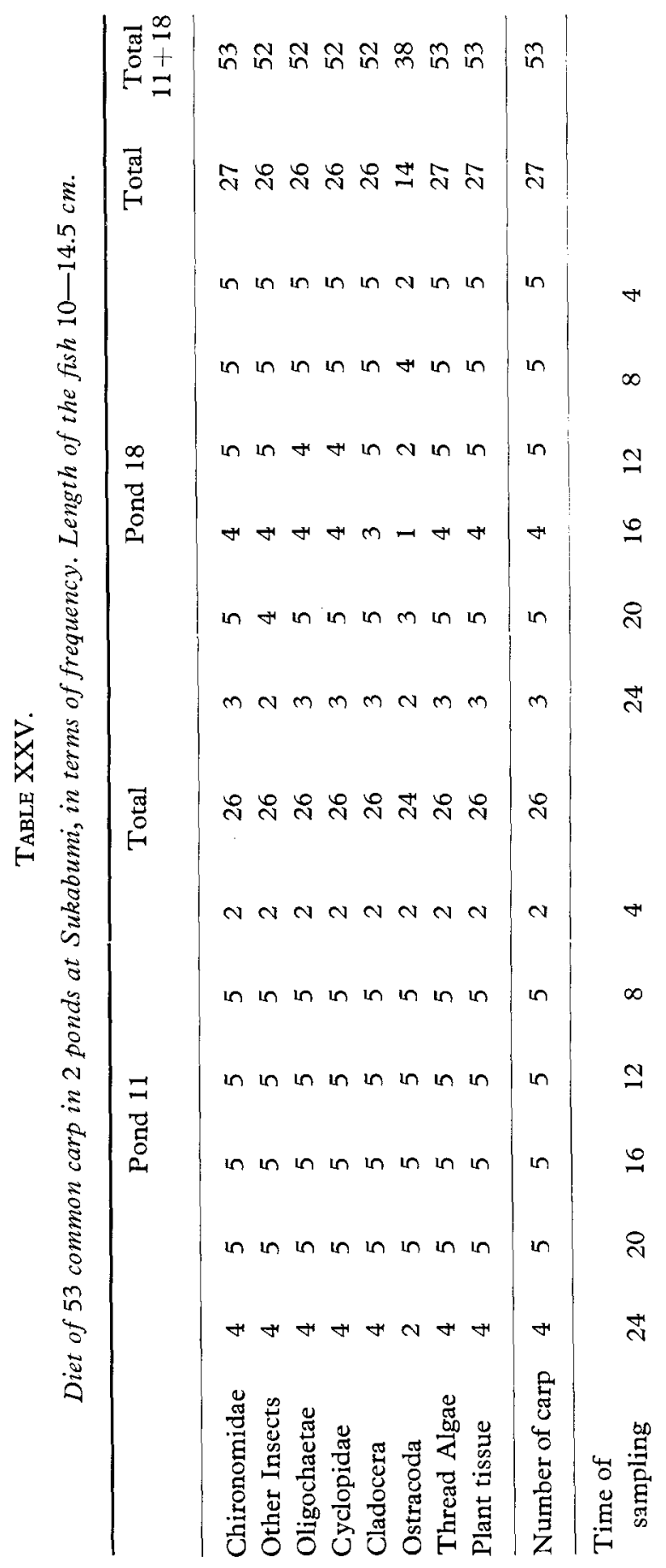




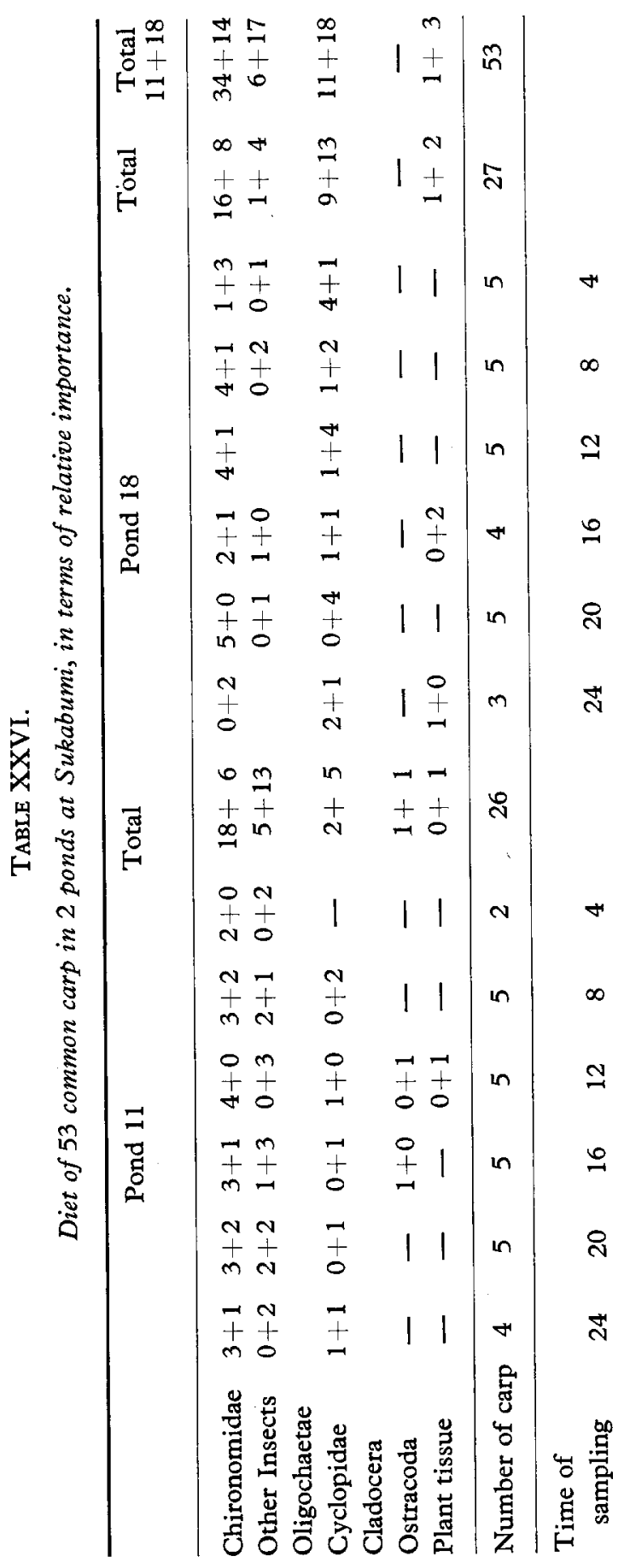


TABLE XXVII.

Diet of 53 common carp in 2 ponds at Sukabumi, in terms of Volume in $\mathrm{mm}^{3}$.

\begin{tabular}{|c|c|c|c|c|c|c|c|}
\hline \multirow[b]{2}{*}{ Chironomidae } & \multirow[b]{2}{*}{248} & \multicolumn{4}{|c|}{ Pond 11} & & \multirow{2}{*}{$\frac{\text { Total } \mathrm{mm}^{3}}{1605}$} \\
\hline & & 270 & 280.5 & 424.5 & 252 & 130.5 & \\
\hline Other Insects & 117 & 215 & 258 & 153 & 204 & 107 & 1054 \\
\hline Oligochaetae & 21 & 28.5 & 54 & 29.5 & 25.5 & 17 & 175.5 \\
\hline Cyclopidae & 86.5 & 78 & 171.5 & 189 & 141 & 76 & 742 \\
\hline Cladocera & 15 & 11.5 & 29 & 33 & 56.5 & 26 & 171 \\
\hline Ostracoda & 1 & 4 & 62.5 & 61.5 & 4.5 & 7 & 140.5 \\
\hline Thread Algae & 27.5 & 33 & 38 & 24 & 29 & 9 & 160.5 \\
\hline Plant tissue & 60 & 75 & 75 & 75 & 75 & 30 & 390 \\
\hline Number of carp & 4 & 5 & 5 & 5 & 5 & 2 & 26 \\
\hline \multirow[t]{2}{*}{ Time of sampling } & 24 & 20 & 16 & 12 & 8 & 4 & \\
\hline & \multicolumn{6}{|c|}{ Pond 18} & Total $\mathrm{mm}^{3}$ \\
\hline Chironomidae & 63 & 477.5 & 190 & 388.5 & 673.5 & 289 & 2031.5 \\
\hline Other Insects & 36 & 67 & 102 & 72 & 258 & 149 & 684 \\
\hline Oligochaetae & 7.5 & 50 & 15.5 & 11. & 46.5 & 32.5 & 163 \\
\hline Cyclopidae & 127 & 216 & 209.5 & 355 & 357.5 & 588.5 & 1853.5 \\
\hline Cladocera & 1.5 & 6.5 & 5.5 & 26.5 & 8.5 & 22.5 & 71 \\
\hline Ostracoda & - & 0.5 & 0.5 & 1.5 & - & 一 & 2.5 \\
\hline Thread Algae & 1.0 & 13 & 9.5 & 6 & 13 & 6 & 48.5 \\
\hline Plant tissue & 90 & 75 & 105 & 75 & 75 & 75 & 495 \\
\hline Number of carp & 3 & 5 & 4 & 5 & 5 & 5 & 27 \\
\hline Time of sampling & 24 & 20 & 16 & 12 & 8 & 4 & \\
\hline
\end{tabular}

TABle XXVIII

Diet of 53 common carp in 2 ponds at Sukabumi, in terms of Volume in percentage.

\begin{tabular}{lccccccc}
\hline & \multicolumn{8}{c}{ Pond 11 } & & Average \\
\hline Chironomidae & 43 & 37.8 & 29 & 43 & 32 & 32.6 & 36.2 \\
Other Insects & 20.7 & 30 & 26.7 & 15.5 & 26 & 26.7 & 24.3 \\
Oligochaetae & 3.6 & 4 & 5.5 & 3 & 3.3 & 4.2 & 3.9 \\
Cyclopidae & 15 & 10.9 & 17.7 & 19 & 18 & 19 & 16.6 \\
Cladocera & 2.6 & 1.6 & 3 & 3.3 & 7.2 & 6.5 & 4 \\
Ostracoda & - & 0.5 & 6.5 & 6.2 & 0.6 & 1.7 & 2.6 \\
Thread Algae & 4.7 & 4.5 & 3.9 & 2.4 & 3.7 & 2.2 & 3.5 \\
Plant tissue & 10.4 & 10.5 & 7.8 & 7.6 & 9.5 & 7.5 & 8.9 \\
\hline Number of carp & 4 & 5 & 5 & 5 & 5 & 2 & 26 \\
\hline Time of sampling & 24 & 20 & 16 & 12 & 8 & 4 &
\end{tabular}




\begin{tabular}{lcccccccc}
\hline & \multicolumn{1}{c}{ Pond 18 } & & Average \\
\hline Chironomidae & 19.3 & 52.8 & 29.3 & 38.1 & 47 & 25 & 35.3 \\
Other Insects & 11 & 7.4 & 16 & 8.1 & 18 & 12.8 & 12.2 \\
Oligochaetae & 2.3 & 5.5 & 2.4 & 1.2 & 3.2 & 2.8 & 2.9 \\
Cyclopidae & 39 & 23.9 & 33.4 & 40.2 & 25 & 50.5 & 35.3 \\
Cladocera & 0.5 & 0.7 & 0.9 & 3 & 0.6 & 1.9 & 1.3 \\
Ostracoda & - & - & -1.4 & - & - & - & - \\
Thread Algae & 0.3 & 1.4 & 1.5 & 0.7 & 0.9 & 0.5 & 0.9 \\
Plant tissue & 27.6 & 8.3 & 16.5 & 8.5 & 5.2 & 6.4 & 12.1 \\
\hline Number of carp & 3 & 5 & 4 & 5 & 5 & 5 & 27 \\
\hline Time of sampling & 24 & 20 & 16 & 12 & 8 & 4 &
\end{tabular}

In the above tables no. XXV, XXVI, XXVII, and XXVIII, the composition of the guts contents is shown in terms of frequency, relative importance, volume in $\mathrm{mm}^{3}$ and volume in percentages, as was indicated previously.

Dealing now with larger carp from a different environment we had to make a slightly different classification of the biota.

These tables show that the carp feeds on: Chironomidae, Crustaceae - mainly Cyclopidae -, Insect larvae other than Chironomidae, and vegetable detritus, in the order mentioned.

In table XXIX the differences between the guts contents of carp from each pond, judged by the three criteria used, is summarized.

TABLE XXIX.

Differences between the guts contents of carp from 2 ponds at Sukabumi.

\begin{tabular}{lll}
\hline Criterium & \multicolumn{1}{c}{ Pond 11 } & \multicolumn{1}{c}{ Pond 18 } \\
\hline Frequency & more Ostracoda & \\
Rel. Importance & $\begin{array}{l}\text { more Insects } \\
\text { more Ostracoda }\end{array}$ & $\begin{array}{l}\text { more Cyclopidae } \\
\text { more vegetable detritus } \\
\text { Volume }\end{array}$ \\
& $\begin{array}{l}\text { more Insects } \\
\text { more Ostracoda }\end{array}$ & \\
& more Thread Algae &
\end{tabular}

If we revert to Table XXIII, giving the food supply in both ponds, we find that:

1. Although the higher aquatic vegetation in no. 11 contained much more Chironomidae than the scanty vegetation in no. 18, these larvae were ingested in comparable numbers in both cases and the greater supply in pond 11 is not reflected in the content of the guts, probably because other insects and larvae were abundant.

2. Crustaceae from the open water formed a most important source of food. The larger supply of Cyclopidae in pond 18 and of 
Ostracoda in no 11 , is clearly reflected in the guts contents, as well as the greater supply of Crustaceae as a whole in pond 18. The percentages found were: pond $11=23.2 \%$ and pond $18=$ $36.6 \%$. As was stated earlier Crustaceae in Indonesian ponds were found to show a slight nocturnal movement towards the surface. However no reliable differences could be found in the total volumes of Crustaceae sampled an intervals of 4 hours during 24 hours in either pond, probably because the carp takes the Crustaceae in all strata of the water.

3. The greater abundance of aquatic insects in no 11 resulted in a greater utilization of this food. In both ponds this source of food was more plentiful than in Bogor and therefore more drawn upon.

4. The large supply of vegetable food originating from the plentiful aquatic vegetation in ponds 11 was used by the carp. Such food was almost absent from pond 18 .

5. Although more thread algae were available in pond 18 , the carp did not draw on this source to any greater extent than in the other pond, which shows that this food is not taken by preference.

6. The greater abundance of Oligochaetae in no 11 was not reflected in the guts contents, neither could any difference be observed between the ingestion of these worms during the night and during the day, although there did seem to be a difference as far as the mud samples were concerned.

We therefore come to the conclusion that the diet of the common carp is dictated here to a marked extent by the local supply of food, except with respect to Crustaceae which are taken by preference and Thread Algae which are avoided.

The samples from Palembang (South Sumatra) originated from 4 different ponds.

Relevant data on these ponds will be found in Table XXX.

In table XXXI, XXXII and XXXIII a survey is given of the supply of natural food occurring in the open water - net and nannoplankton samples - in the mud on the bottom and among the vegetation along the bunds, together with organisms among the roots of floating masses of Eichhhornia in these ponds.

In the table XXXIV the results are shown of an analysis of the guts contents of 18 carp from these ponds. In accordance with the more varied diet natural food was grouped in a more specified way. By means of one or two crosses the abundance of organisms not attaining a total volume of $0.5 \mathrm{~mm}^{3}$ in the total contents of all carp of the samples were shown. The tables were limited to total volume in $\mathrm{mm}^{3}$ in all carp combined.

Studying the figures of table XXXIV it should not be forgotten that the total number of guts examined was not the same for each 
TABle XXX.

Data on 4 ponds at Palembang, where guts contents of common carp were studied.

\begin{tabular}{|c|c|c|c|c|}
\hline Name of Pond. & $\begin{array}{c}\text { Pulau } \\
\text { Panggang }\end{array}$ & $\begin{array}{c}\text { Pagar Alam } \\
3\end{array}$ & Gunung Kaja & $\begin{array}{l}\text { Sungai } \\
\text { Selintjah }\end{array}$ \\
\hline Surface in $\mathrm{m}^{2}$ & 50 & 700 & 750 & 1444 \\
\hline & 825 & 700 & 715 & Sea \\
\hline $\begin{array}{l}\text { in } \mathrm{cm} \\
\text { Depth of mud layer }\end{array}$ & 40 & 80 & 70 & 80 \\
\hline in $\mathrm{cm}$ & 15 & 50 & $\begin{array}{c}50 \\
\text { (black) }\end{array}$ & $\begin{array}{c}50 \\
\text { (grey) }\end{array}$ \\
\hline $\begin{array}{l}\text { pH at noon } \\
\text { Methylorange }\end{array}$ & $6-7$ & 7 & $8-9$ & 5 \\
\hline $\begin{array}{l}\text { alkalinity } \\
\text { Aquatic } \\
\text { vegetation }\end{array}$ & $\begin{array}{c}1 \\
\text { absent }\end{array}$ & $\begin{array}{l}1 \\
\text { some Spi- } \\
\text { rogyra }\end{array}$ & $\begin{array}{c}1 \\
\text { well develo- } \\
\text { ped, Najas, } \\
\text { Potamogeton, } \\
\text { Spirogyra }\end{array}$ & \begin{tabular}{l}
\multicolumn{1}{c}{0.6} \\
abundant, \\
Hydrilla, \\
Eichhornia, \\
Monochoria,
\end{tabular} \\
\hline Shore vegetation & Panicum & Panicum & absent & absent \\
\hline $\begin{array}{l}\text { Surface film on the } \\
\text { water }\end{array}$ & $\begin{array}{l}\text { Euglena, } \\
\text { thick }\end{array}$ & absent & absent & $\begin{array}{c}\text { slight film } \\
\text { of } \\
\text { Euglena acus } \\
\text { Ehrb. } \\
\text { E. gracilis Kl } \\
\text { and } \\
\text { E. spirogyra } \\
\text { Ehrb. }\end{array}$ \\
\hline Water supply & $\begin{array}{l}\text { from } \\
\text { village, } \\
\text { muddy }\end{array}$ & $\begin{array}{l}\text { from rice- } \\
\text { fields, } \\
\text { muddy }\end{array}$ & from village & $\begin{array}{l}\text { from village } \\
\text { unfertile }\end{array}$ \\
\hline Manuring & faeces & absent & kitchen waste & absent \\
\hline $\begin{array}{l}\text { Total length of } \\
\text { carp in } \mathrm{cm}\end{array}$ & \pm 25 & $\pm 7 \frac{1}{2}$ & \pm 4 & \pm 16 \\
\hline $\begin{array}{c}\text { Number of samples } \\
\text { of carp. }\end{array}$ & 2 & 4 & 8 & 4 \\
\hline
\end{tabular}


TABLE XXXI

Composition of net- and nannoplankton in 4 ponds near Palembang.

\begin{tabular}{|c|c|c|c|c|}
\hline & $\begin{array}{c}\text { Pulau } \\
\text { Panggang }\end{array}$ & $\begin{array}{l}\text { Pagar } \\
\text { Alam } 3\end{array}$ & $\underset{\text { Kaja }}{\text { Gunung }}$ & $\begin{array}{l}\text { Sungai } \\
\text { Selintjah }\end{array}$ \\
\hline Phacus & $\mathrm{x}$ & & & \\
\hline Euglena & $\mathrm{xxx}$ & $\mathrm{x}$ & & $\mathrm{xxx}$ \\
\hline Peridinium & & & $\mathrm{xxx}$ & \\
\hline Oscillatoria & & & & $\mathrm{xx}$ \\
\hline Chroococcus & $\mathrm{xxx}$ & & & \\
\hline Pediastrum & $x$ & & & \\
\hline Scenedesmus & $\mathrm{xx}$ & & & $\mathrm{x}$ \\
\hline Diatomeae & $\mathrm{xx}$ & $\mathrm{x}$ & $\mathbf{x}$ & $x x$ \\
\hline Branchionus & $x x$ & & $\mathrm{xx}$ & $\mathrm{x}$ \\
\hline Triarthra & $\mathrm{xx}$ & & $\mathrm{x}$ & $\mathrm{x}$ \\
\hline Cyclopidae & $\mathrm{x}$ & $\mathrm{xx}$ & $\mathrm{xx}$ & $\mathrm{x}$ \\
\hline \multirow{2}{*}{\multicolumn{5}{|c|}{$\begin{array}{l}\text { Cyclestheria } \\
\text { hislopi (Baird) }\end{array}$}} \\
\hline & & & & \\
\hline $\begin{array}{l}\text { Total volume in } \\
\mathrm{mm}^{3} / \text { litre }\end{array}$ & 12 & 0,1 & 2 & 0.3 \\
\hline
\end{tabular}

TABle XXXII

Organisms in the mud layer of 4 ponds near Palembang. Expressed in numbers or in abundance, when not counted.

\begin{tabular}{|c|c|c|c|c|}
\hline & $\begin{array}{c}\text { Pulau } \\
\text { Panggang }\end{array}$ & $\begin{array}{l}\text { Pagar } \\
\quad \text { Alam } 3\end{array}$ & $\underset{\text { Kaja }}{\text { Gunung }}$ & $\begin{array}{r}\text { Sungai } \\
\text { Selintjah }\end{array}$ \\
\hline \multicolumn{5}{|l|}{ Diptera larvae } \\
\hline $\begin{array}{l}\text { Chironomidae } \\
\text { (plumosus type) }\end{array}$ & 1 & 1 & & \\
\hline Tanypidae & & 4 & & \\
\hline $\begin{array}{l}\text { Ceratopogonidae } \\
\text { (Bezzia type) }\end{array}$ & & 4 & & \\
\hline \multicolumn{5}{|l|}{ Oligochaetae } \\
\hline $\begin{array}{l}\text { Dero limosa } \\
\text { Limnodrilus hoff- }\end{array}$ & 4 & & & \\
\hline meisteri & 6 & 4 & & \\
\hline small Snails & & 3 & & \\
\hline \multicolumn{5}{|l|}{ Algae } \\
\hline Spirogyra & & $\mathrm{xx}$ & & \\
\hline Diatomeae & & $x x$ & & \\
\hline $\begin{array}{c}\text { Lyngbya maior } \\
\text { Men. }\end{array}$ & & & thick layer & \\
\hline Vegetable detritus & $\mathrm{xx}$ & $\mathrm{xx}$ & $\mathrm{xxx}$ & $\mathrm{xxx}$ \\
\hline $\begin{array}{l}\text { Volume of mud } \\
\text { sample in } \mathrm{mm}^{3} .\end{array}$ & 50 & 85 & 60 & 70 \\
\hline
\end{tabular}


TABLE XXXIII.

Flora and fauna among shore vegetation and among the roots of floating Eichhornia in 4 ponds near Palembang.

Expressed in numbers or in abundance when not counted.

\begin{tabular}{|c|c|c|c|c|c|}
\hline & \multirow[t]{2}{*}{$\begin{array}{c}\text { Pulau } \\
\text { Panggang }\end{array}$} & \multirow[t]{2}{*}{$\begin{array}{l}\text { Pagar } \\
\text { Alam } 3\end{array}$} & \multirow[t]{2}{*}{$\underset{\text { Kaja }}{\text { Gunung }}$} & \multicolumn{2}{|c|}{$\begin{array}{l}\text { Sungai } \\
\text { Selintjah }\end{array}$} \\
\hline & & & & $\begin{array}{l}\text { Among } \\
\text { veget. }\end{array}$ & $\begin{array}{c}\text { Among } \\
\text { Eich. } \\
\text { hornia }\end{array}$ \\
\hline Chironomidae & 920 & 12 & & & \\
\hline $\begin{array}{l}\text { egg-clusters of Ch. } \\
\text { Tanypidae }\end{array}$ & $\mathrm{xxx}$ & 2 & & & \\
\hline Paratanytarsus & & & 1 & 73 & 9 \\
\hline Tabanidae & & & & 2 & \\
\hline Dero limosa & 2 & & & 2 & 4 \\
\hline Limnodrilus hoffmeisteri & 3 & 8 & & & \\
\hline Branchiura sowerbyi & & 1 & & & \\
\hline Aulophorus furcatus & & 1 & & 24 & \\
\hline Aulodrilus kashi St. & & & & 12 & \\
\hline Naidium sp. & & & & 5 & 1 \\
\hline \multicolumn{6}{|l|}{ Nais paraguayensis } \\
\hline v. aequalis & & & & 4 & 7 \\
\hline Nais paraguayensis & & & & 13 & 24 \\
\hline Nais pectinata & & & & 3 & \\
\hline Nais sp. & & & & 5 & \\
\hline Pristina proboscidea & & & & & 11 \\
\hline Pristina longiseta & & & & 1 & \\
\hline unidentified remains & & & & 3 & \\
\hline Sphaerodema rustica (Fab.) & 3 & & & & \\
\hline Ranatra elongata Fab. & 1 & & & & \\
\hline \multicolumn{6}{|l|}{ Micronecta quadristrigata } \\
\hline Bred. & 1 & & & & \\
\hline Microvelia spp. & 3 & & & & \\
\hline Procloeon bifidum larva & 7 & & & & \\
\hline Heloechares larva & 3 & & & & 1 \\
\hline Ephemeridae larva & & & 2 & & 6 \\
\hline Nematoda & $\mathrm{xx}$ & & & & \\
\hline Ostracoda & $\mathrm{xx}$ & $\mathbf{x}$ & & & \\
\hline Cyclopidae & $x x$ & & & & \\
\hline Cyclestheria hislopi & & & & 15 & 114 \\
\hline Diatomeae & $\mathbf{x x}$ & $\mathbf{x}$ & $\mathbf{x}$ & $\mathrm{x}$ & \\
\hline Peridineum & & & $\mathbf{x}$ & & \\
\hline Euglena & $\mathrm{xxx}$ & & & $\mathbf{x}$ & \\
\hline Desmidiaceae & & $\mathbf{x}$ & $\mathrm{x}$ & & \\
\hline Green thread algae & $\mathbf{x}$ & $\mathbf{x x}$ & & & \\
\hline Lyngbya $\quad M$ & & & $\mathrm{xxx}$ & & \\
\hline Protozoa & $\mathbf{x x}$ & & & & \\
\hline Volume of sample & $\begin{array}{l}11.8 \text { gram } \\
\text { grass } \\
13 \mathrm{ccm} \\
\text { mud }\end{array}$ & $\begin{array}{l}15 \text { gram } \\
\text { plants } \\
2 \mathrm{cc} \\
\text { mud }\end{array}$ & $\begin{array}{c}8 \text { gram } \\
\text { plants } \\
20 \mathrm{cc} \mathrm{mud}\end{array}$ & $\begin{array}{l}3 \text { gram } \\
\text { plants }\end{array}$ & $\begin{array}{l}11 \mathrm{gr} . \\
\text { Eichh. }\end{array}$ \\
\hline
\end{tabular}


TABLE XXXIV.

Guts contents of 18 carp from 4 ponds near Palembang. Total volumes in $\mathrm{mm}^{3}$ for all fish of the sample. Crosses used for items with lower volume than $0.5 \mathrm{~mm}^{3}$.

\begin{tabular}{|c|c|c|c|c|}
\hline & $\begin{array}{c}\text { Pulau } \\
\text { Panggang }\end{array}$ & $\begin{array}{c}\text { Pagar } \\
\text { Alam } 3\end{array}$ & $\underset{\text { Kaja }}{\text { Gunung }}$ & $\begin{array}{l}\text { Sungai } \\
\text { Selintjah }\end{array}$ \\
\hline Chironomidae & 780 & 12 & 103 & 134 \\
\hline Ceratopogonidae & 0.6 & & & \\
\hline Odonata lar. & 2 & & & \\
\hline other Insects lar. & & 23 & 14 & 43 \\
\hline Oligochaetae & 301 & $\mathrm{x}$ & 1 & 70 \\
\hline Cyclopidae & 40 & 57 & 13.5 & 203 \\
\hline Ostracoda & $\mathrm{x}$ & $\mathrm{x}$ & & 26 \\
\hline Cyclestheria & 0.6 & & & 107 \\
\hline Cladocera & & 27 & 3 & \\
\hline Rotatoria & & & $\mathrm{x}$ & $\mathrm{x}$ \\
\hline Euglena & $\mathrm{xx}$ & & & $\mathrm{x}$ \\
\hline Phacus & $\mathrm{xx}$ & & & \\
\hline Diatomeae & $\mathrm{xxx}$ & & $\mathrm{xx}$ & $\mathrm{xx}$ \\
\hline Closterium & & & $\mathrm{x}$ & $\mathrm{x}$ \\
\hline Lyngbya & $\mathrm{xx}$ & & $\mathrm{xx}$ & \\
\hline Spirogyra & $\mathrm{x}$ & 9 & 0.6 & \\
\hline Plant tissue & 65 & 5 & 52 & 350 \\
\hline Length of carp in $\mathrm{cm}$ & 30 & 7.5 & $3-5$ & $14-18$ \\
\hline Number of carp & 2 & 4 & 8 & 4 \\
\hline
\end{tabular}

pond and that the carps differed in seize, as indicated in the table. In the guts of the fish from Pagar Alam 3 we recognized Veliidae and Corixidae among the remains of insects, Diaphanosoma and Mesocyclops among the Cyclopidae and Bosmina among the Cladocera. Among those from Sungai Selintjah adult Veliidae, Corixidae, ants and larvae of Hydrophilidae among insects, and Aulodrilus Limnodrilus, Aulophorus and Nais paraguayensis among the worms by means of the chetae.

Table XXXV contains a summary of the food supply and its utilization in these four ponds.

From the data contained in this table we can draw the following conclusions:

1. Plant tissue - vegetable detritus-, although plentiful even in the ponds with scanty vegetation, was never ingested in equivalent quantities, the carp giving preference to other kinds of food.

2. Thread algae were only encountered in the guts of carp from ponds in which Spirogyra or Lyngbya were abundant, but in small quantities compared with the supply.

3. Insect larvae and worms from the bottom and Crustaceae from the open water and among the littoral vegetation were taken by the carp in quantities in accordance with local availability. 
TABLE XXXV.

Food supply and utilization in 4 ponds near Palembang.

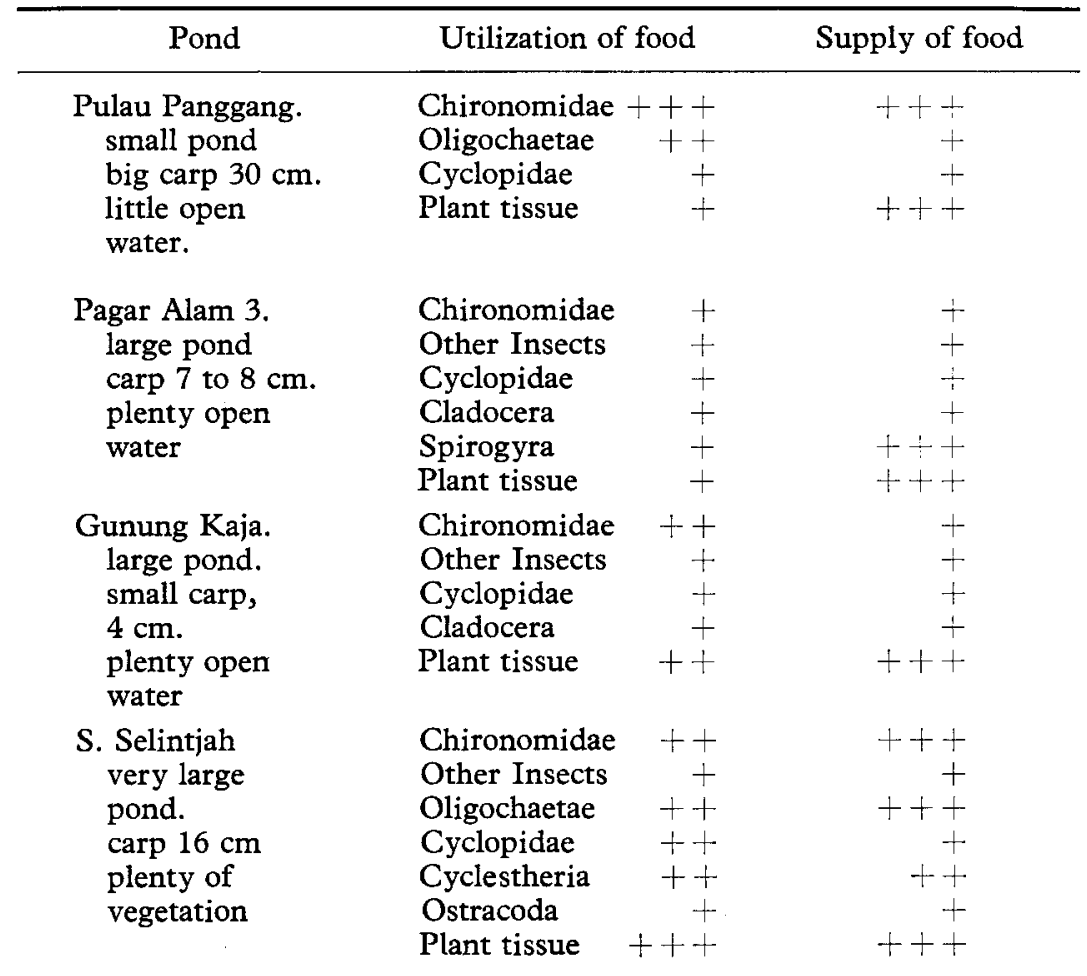

SECTION 4.

RELATION BETWEEN GUTS CONTENTS AND AVAILABILITY OF NATURAL FOOD IN A SEWAGE POND AT BODJONG LOA, BANDUNG.

\section{SITUATION AND EXPLOITATION OF THE POND}

Near the southern border of the city of Bandung, the capital of West Java, 373 fresh water fish ponds are found, measuring together $182.5 \mathrm{ha}$, situated at an altitude of $750 \mathrm{~m}$ above sea-level.

This area, known as Bodjong Loa, is famous for its high yields of fish - from 2000 to $5000 \mathrm{~kg} / \mathrm{ha} /$ year - a result of the combination of fertile soil, most fertile water from the sewers of the town, and suitable methods of cultivation.

The ponds are shallow, measuring $10-30 \mathrm{~cm}$ at the inlet, against $40-60 \mathrm{~cm}$ at the outlet. Mud accumulates rapidly on the bottom and has to be removed every 3 or 4 month. The ponds are stocked with a mixture of either $60 \%$ or $70 \%$ Tilapia mossambica, $20 \%$ or $10 \%$ 
Cyprinus carpio and $20 \%$ Helostoma temmincki, or $80 \%$ Tilapia and $20 \%$ Cyprinus by weight.

The fish are stocked at a length of $5-8 \mathrm{~cm}$ and at a rate of $100-$ $150 \mathrm{~kg} / \mathrm{ha}$ for rearing ponds and cropped after 1 month at a weight of 20 - 30 gram. Cropping takes place 10 times a year, 2 months being used for improvement and maintenance of the ponds. During the rainy season when water is plentiful cropping is carried out by means of total draining, during the dry season water is sometimes scarce and the fish are gathered with screens. Some ponds are used as nursery ponds.

The pond investigated was a rearing pond of $5600 \mathrm{~m}^{2}$, in front of the residence of the prominent pond owner Hadji KosasiH, who kindly gave us numerous facilities throughout the work on the spot.

This pond was partly drained, cropped with screens and restocked with $20 \mathrm{~kg}$ Helostoma of $6 \mathrm{~cm}, 10 \mathrm{~kg}$ common carp of 7-10 cm and $70 \mathrm{~kg}$ mudjair of $6 \mathrm{~cm}$, every month and completely drained and overhauled every 4 months.

Only the amount of water leaving the pond at the outlet could be measured with some degree of accuracy, but the amounts leaving by seepage and evaporation as well as the amount entering the inlet could only be guessed. We obtained the impression that the pond is completely replenished with water within one month.

\section{HIGHER VEGETATION}

Allong the shallow parts of the shores a higher vegetation is found of Althernanthera, Calocasia, Polypodium, fussicua and grasses.

Floating on the water are Pistia stratiotes L. and Limnobium stoloniferum (G. M. GRIS).

\section{AQUATIC VEFETATION}

No rooted aquatic vegetation is present. The water shows a greenish colour and the surface is covered with patches of Euglena spp, the red species sanguinea and heamatococcus as well as the green ones Ehrenbergi, acus and others. Together with Cyanophyceae they often form a scum on the surface.

In July 195412 plankton samples were taken by HASANUDDIN SAANIN at intervals of 2 hours during a period of 24 hours. In October 1956 the author took several samples of net - and nannoplankton. The result of the microscopic examination of these samples is given in table XXXVI.

Besides these organisms the water contains many bacteria. Forms of the Sarcina-type and the Spirillum-type were most abundant. Some Hydrarachnidae were observed and some eggs of 
TABle XXXVI.

Net and Nannoplankton of the pond at Bodjong Loa ( $M=$,en masse").

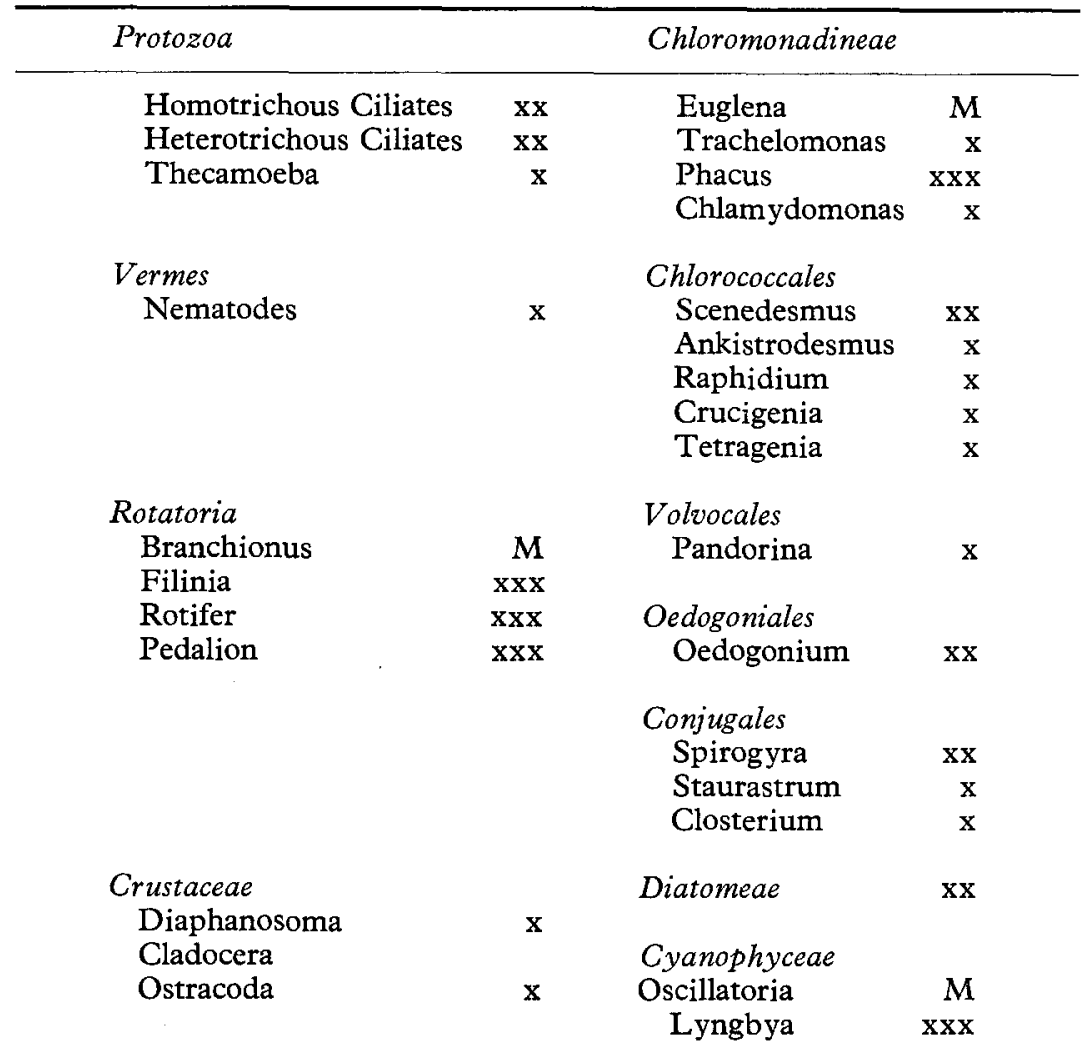

worms living as parasites inside the guts of men such as Ascaris and Trichocephalus, a result of the inflow of water from sewers of the city.

The guppy, Lebistes reticulatus, was most frequent in the pond and was observed in all stages. The tiny fry was so abundant that many plankton samples strained from 12 liter of water were found to contain a dozen young Lebistes, mainly at night when the fish are at the surface. Common organisms notably rare were Notonectidae and snails.

\section{BOTTOM}

The bottom of the pond was covered with a layer of black soft mud full of coarse and fine remains of vegetation, chitinous sceletons of insects and many bones, scales and other parts of the sceleton of small fish. As the inflowing water is full of kitchen-waste and human excreta much of this material will be of allochtonous origin. 
Animal life was rare in this layer of mud. Only some Nematodes, Nais, Limnodrilus and Chaetenotus and an occasional Chironomide, Ceratopogonide, Culicide and Muscide were found on shallow spots, many deeper parts did not show any animal life. Empty shells of Diatoms were encountered in small numbers.

Animal life here is in strong contrast with the situation found in the running water of the sewers leading into the pond. The bottom of those sewers is covered in many places with a dense growth of Oligochaetae and red Chironomidae even to such an extent that these organisms are collected in bulk and sold to owners of aquaria as food for their fish.

\section{HYD ROCHEMISTRY}

The water of the pond was investigated on the spot in October 1956. Owing to the heavy bloom of small filamentous blue-green algae and the large amount of silt the Secchi disc disappears already at $12 \mathrm{~cm}$. As Bandung is situated in a region rich in lime the Calcium contents of the inland waters is high and in this case the sewage from the city adds to the mineral contents of the water. A methyl orange alcalinity (acid combining capacity) of 4 was found. Other features were examined at various times of the day and night with results given in table XXXVII.

TABLE XXXVII.

Hydrochemical data of the pond.

\begin{tabular}{rcrrrl}
\hline Time & $\begin{array}{c}\text { Temperature } \\
\text { air }\end{array}$ & $\mathrm{pH}$ & $\% \mathrm{O}_{2}$ & $\begin{array}{c}\text { Temperature } \\
\text { water }\end{array}$ \\
\cline { 1 - 1 } 7.30 & & 7.4 & 0 & 24.0 & surface \\
7.30 & 24 & 7.6 & 0 & 23.5 & bottom $=70 \mathrm{~cm}$ \\
8.15 & & & 10 & & surface \\
8.45 & & 7.7 & 64 & 26.0 & surface \\
8.45 & 26.25 & 7.6 & 46 & 26.0 & bottom $=70 \mathrm{~cm}$ \\
12.00 & & 7.7 & 185 & 29.0 & surface \\
12.00 & 28.0 & 7.4 & 21 & 27.0 & bottom $=70 \mathrm{~cm}$ \\
18.00 & & 7.5 & 4 & 29.5 & surface \\
18.00 & 25.5 & 7.1 & 0 & 28.2 & bottom $=70 \mathrm{~cm}$ \\
22.30 & & 7.6 & 0 & 27.5 & surface \\
22.30 & 23.0 & 7.0 & 0 & 26.2 & bottom $=70 \mathrm{~cm}$ \\
4.00 & & 7.0 & 0 & 25.0 & surface \\
4.00 & 21.5 & 7.0 & 0 & 24.8 & bottom $=70 \mathrm{~cm}$
\end{tabular}

\section{DISCUSSION OP THE ENVIRONMENT}

The above data enable us to form a picture of the suitability of the environment from the point of view of fishculture. 
The inflowing water carries a large amount of particulate and dissolved organic substances and silt. This material covers the bottom with a thick layer and oxygen-absorbing processes of mineralisation will be most active at the high temperature and the high concentration of Calcium.

For this reason the bottom itself and the water near it are devoid of oxygen during a large part of the day and night. During the hours of sunshine the heavy bloom of phytoplankton - mainly small filamentous Cyanophyceae $65-75 \mu$ in length - will create a situation of super-saturation at the surface and mixing of the shallow water will carry some oxygen to the lower strata. However, oxygen-absorbing processes predominate to such an extent over assimilation that according to our sampling methods even the surface does not contain any oxygen during part of the early morning and the night. No doubt the uppermost layers of the water, where oxygen from the air is attracted at a rapid rate by the large gradient of diffusion existing between the water and the air, will still contain some oxygen, but with the usual Winkler method, where a sample bottle of $100 \mathrm{cc}$ is used, none could be detected at various times.

The poor oxygenation, the thickness and softness of this layer of mud, together with its rapid accrement are the reasons for the difference between the outburst of animal life on the bottom of the sewers and the paucity on the bottom of the pond. Therefore the bottom does not contain many organisms suitable as food for fish.

In the water enormous numbers of small, filamentous Cyanophyceae, Euglena's, Protococcales and Rotatoria are found, but bigger zooplankton is scarce. Thus we may conclude that for filter-feeders food is plentiful but that the usual food for the common carp is scarce.

FOOD OF THE VARIOUS FISHES

\section{L e bis te s.}

Lebistes of all size were seen in large quantities. During the night they come to the surface sucking in the uppermost layer still containing some oxygen. The enormous fecundity of this species is well known. In a gravid female of $43 \mathrm{~mm}$ total length, we counted 63 young. Four lots of different size were examined with results shown in table XXXVIII.

\section{Tilapia mossambica (Mudjair)}

As no segregation of the sexes is practised here Mudjair breeds profusely in the pond and many shoals of young can be seen. Four lots of different size were examined, as shown in table XXXIX.

The digestability of the threads of blue-green algae can be demon- 
TABLE XXXVIII.

Guts contents of Lebistes from the pond at Bodjong Loa.

\begin{tabular}{rrl}
\hline Number & $\begin{array}{c}\text { total length } \\
\text { in mm. }\end{array}$ & \multicolumn{1}{c}{ Contents of the guts. } \\
\hline 16 & $9-16$ & $\begin{array}{l}\text { Rotatoria frequent. The eggs were only partly } \\
\text { digested. Diaphanosoma. Protococcales, partly di- } \\
\text { gested. Cyanophyceae almost undigested. } \\
\text { A single Chironomide larva, width of head-capsule } \\
100 \mu \text { in a fish of 15 mm. Phacus, partly digested. }\end{array}$ \\
& & $\begin{array}{l}\text { Euglena idem. } \\
\text { idem. }\end{array}$ \\
7 & $18-22$ & $\begin{array}{l}\text { idem. Unidentifiable green detritus. Diatoms. } \\
\text { idem. Diatoms fairly frequent. Detritus. }\end{array}$
\end{tabular}

strated by a comparison between the microscopic habitus of the threads from the stomach and those from the hindermost part of the guts.

Diatomeae and Rotatoria were taken in smaller numbers than was done by the Lebistes. Some guts of the bigger fish were not completely filled, some even very sparely.

TABLE XXXIX.

Guts contents of Mudjair from the pond.

\begin{tabular}{crl}
\hline Number & $\begin{array}{c}\text { total length } \\
\text { in mm }\end{array}$ & \multicolumn{1}{c}{ Guts contents. } \\
\hline 4 & $15-22$ & $\begin{array}{l}\text { Cyanophyceae fairly well digested. Single celled green } \\
\text { algae partly digested. } \\
\text { Diatoms. Rotatoria. } \\
\text { idem. green detritus. }\end{array}$ \\
4 & $26-34$ & $\begin{array}{l}\text { idem. } \\
\text { idem. }\end{array}$ \\
7 & $55-64$ idem. & idem. Euglena. Mud.
\end{tabular}

3. Helostoma temmincki ( $\mathrm{Tambakan}$ )

Helostoma forms $20 \%$ of the stock. In July 1954 this fish was sampled at intervals of 2 hours during 24 hours by HASANUDDIN SAANIN. The guts contents of about a dozen of these fish was examined, together with that of 2 fish sampled in October 1956. All Helostoma measured about $10 \mathrm{~cm}$ in length. The guts contained the same organisms as those of Tilapia, in addition to smaller single celled green algae such as: Raphidium, Ankistrodesmus, Cosmarium, Trachelomonas, all in a stage of partly digestion and some Merismopedia almost undigested. Some eggs of pathogenic worms were also encountered demonstrating the rather undiscriminative straining of the plankton. 
4. C y prinus car pio (com mon carp)

In July 1954 HasanUdDin SAANIN collected 12 times 10 carp at intervals of 2 hours during a period of 24 hours. The guts of these carp were cut into three sections and after noting the degree of filling of each section the contents were examined. These carp fluctuated in total length from 7 to $12 \mathrm{~cm}$. In October 1956 we collected 8 carp of $6-8 \mathrm{~cm}$ and $10 \mathrm{carp}$ of $9-16 \mathrm{~cm}$, which were treated in the same way. In addition to the usual food of the carp we found remains of small fishes in many cases. Scales, vertebrate, part of fins and bones were easily distinguished, remains of muscles not yet totally digested showed a district xanthoprotein reaction with concentrated $\mathrm{HNO}_{3}$. When sometimes the fish were found in the front part of the guts and therefore still in fairly undigested condition it was easy to identify them as fry of Tilapia and Lebistes. In one carp of $7 \mathrm{~cm}$ no less than 49 Mudjair of $7-10 \mathrm{~mm}$. were encountered immediately behind the gullet.

It followed from an examination of the guts in the described way that 5 carp out of 120 did not show any contents and that the frequency and relative importance $I$ of the various items of food were as shown in table XL.

TABLE XL.

Frequency and relative importance $I$ of various items of natural food in the guts of 120 carp from the pond at Bodjong Loa, of which 5 were empty.

\begin{tabular}{|c|c|c|}
\hline & Frequency. & Relative Importance I \\
\hline Remains of fish & 81 & 45 \\
\hline Insects & 79 & 7 \\
\hline Chironomidae & 27 & \\
\hline Oligochaetae & 25 & 1 \\
\hline Crustaceae & 15 & \\
\hline Euglena & 28 & \\
\hline Cyanophyceae & 37 & 2 \\
\hline \multirow[t]{2}{*}{ Veg. Detritus } & 111 & 60 \\
\hline & & Total 115 \\
\hline
\end{tabular}

It is seen in the table that the items of natural food usually of most importance - Crustaceae, Chironomidae and other insect larvae - do not reach their customary level in this special environment, but that the carp must rely on small fry of Lebistes and Tilapia and vegetable detritus. Inside the guts Cyclopidae, Cladocera, Ostracoda, Oligochaetae and Chironomidae were far more frequent than in the environment, proving that the carp chased those organisms as much as possible, but their low availability forced the fish to take other food.

In October $1956,8 \mathrm{carp}$ of $6-8 \mathrm{~cm}$ and $10 \mathrm{carp}$ of $9-16 \mathrm{~cm}$ in 
total length were collected and examined. The results will not be shown in detail as they did not differ from our findings in the fish collected in 1954. Table XLI summarizes the results in terms of frequency and relative importance I of volume.

\section{TABLE XLI}

Frequency and relative importance 1 of items of natural food in the guts of 8 carp of 6-8 $\mathrm{cm}$ and $10 \mathrm{carp}$ of $9-16 \mathrm{~cm}$ in total length, collected in October 1956

\begin{tabular}{|c|c|c|}
\hline & Frequency & Relative importance \\
\hline Remains of fish & 5 & 5 \\
\hline Chironomidae & 13 & 3 \\
\hline Other Insects & 12 & \\
\hline Oligochaetae & 10 & \\
\hline Crustaceae & 11 & \\
\hline Euglena & 9 & \\
\hline Cyanophyceae & 10 & \\
\hline \multirow[t]{2}{*}{ Veg. Detritus } & 18 & 10 \\
\hline & & Total 18 \\
\hline
\end{tabular}

The carps cultivated in the pond at Bodjong Loa originate from a rearing pond in Tjiateul, a village in the neighbourhood of Bandung. The pond is fed with water from a large irrigation ditch. Some Hydrilla grows in the pond. Here a mixture of Common carp, Puntius javanicus, Helostoma and Tilapia is reared in growing periods of 1 month. Nine carp of about $10 \mathrm{~cm}$ in length were examined. As no data on food production in the pond could be gathered we examined the guts contents in a cursory way only, with results given in table XLII.

TABLE XLII.

Guts contents of 9 carp of $10 \mathrm{~cm}$ total length from the rearing pond at Tjiateul.

\begin{tabular}{|c|c|c|c|c|c|c|c|c|c|c|c|}
\hline No carp. & 1 & 2 & 3 & 4 & 5 & 6 & 7 & 8 & 9 & Freq. & $\begin{array}{l}\text { Rel. } \\
\text { Imp. }\end{array}$ \\
\hline Remains of fish & - & - & $M$ & - & $\mathbf{x x x}$ & - & - & $\mathrm{xxx}$ & - & 3 & 3 \\
\hline Chironomidae & $x x$ & $\mathbf{x}$ & - & $\mathrm{xx}$ & - & - & - & - & - & 4 & - \\
\hline Other Insects & $\mathrm{xx}$ & - & $\mathrm{x}$ & - & - & - & - & - & - & 1 & - \\
\hline Oligochaetae & - & - & - & - & $\mathrm{x}$ & $x x$ & - & - & - & 1 & - \\
\hline Crustaceae & $\mathrm{x}$ & $\mathrm{xx}$ & - & $\mathrm{xxx}$ & $x x$ & $x x$ & $\mathrm{xx}$ & $\mathrm{x}$ & $\mathrm{xxx}$ & 8 & 1 \\
\hline Veg. Detritus & $\mathrm{xxx}$ & $\mathrm{xxx}$ & - & $\mathrm{xxx}$ & $\mathrm{xxx}$ & - & $\mathrm{xxx}$ & $\mathrm{xx}$ & $\mathrm{xxx}$ & 8 & 5 \\
\hline
\end{tabular}

Although the usual way of feeding on Crustaceae, Chironomidae, Oligochaetae and aquatic insects is practiced by these carp in a much more pronounced way than at Bodjong Loa, it follows that here too 
small fry is taken quite frequently and forms an important part of the food of the carp.

\section{Puntius javanicus (t awes)}

Finally we wish to draw attention to the results of an examination of the guts of 10 Puntius javanicus also from the rearing pond at Tjiateul, grown in combination with the above mentioned carp. Ten fish of about $11 \mathrm{~cm}$ in total length were examined. None of the guts were more than half full, 3 were completely empty. The rest was filled with vegetable detritus, Diatomeae, Protococcales and thread algae, but also - to a slight extent - with Crustaceae and insects. One tawes had eaten fry of either Tilapia or Lebistes. As in the case of the common carp the paucity of the usual type of food higher aquatic vegetation in this case - forced the fish to eat unusual food.

\section{DISCUSSION}

The main aspect of this pond is the heavy supply of allochtonous material from outside. This is the reason that the mudlayer on the bottom is so poorly oxygenated and therefore so sparely populated with animals. Mineralizing processes are most active in this mudlayer, carried out by a dense flora of bacteria. The main organisms eating these bacteria are the Protozoa and Rotatoria. These form the food of Lebistes. The carp does not derive much nourishment from these tiny organisms although they are ingested to a certain extent.

The paucity of its normal food forces the carp to rely on fry of Tilapia and Lebistes.

As was stated in the survey of the literature, fish and other vertebrate animals can be eaten by the common carp and even cannibalism can be experimentally induced. As the carp feeds voraciously on insects and their larvae in all stages of its life it is small wonder that, incidentally, fish and fry are devoured. Nowak, Kamprath, CroNHEIM, WALTER and others, mentioned by WUNDER (1.c.), state this phenomenon. WUNDER (l.c.) found fry of bass and Leucaspius in the guts of full-grown carp, CoNTAG (1930) encountered 4 newts, 6-8 $\mathrm{cm}$ in length, in the guts of a $27.5 \mathrm{~cm}$ long carp, weighing 370 gram. It is interesting to note in this respect that the Dubisch method of spawning as well as the Indonesian method with ,kakabans” both segregate the spawners and the larvae as quickly as possible, in the first method by removing the spawners and in the Indonesian method by removing the fibermattings with the eggs. This is a form of protection of the eggs and larvae from the spawners.

In this special environment the ability of the carp to adjust its 
food to such an extent to local availability is the reason why good crops of this fish can be gathered from the pond at all. Organisms as small as Rotatoria and Protozoa are unimportant for the carp of a size such as grown here, even if they do occur in large numbers, and the same holds for the small single-celled or filamentous algae forming the bulk of the microvegetation in this pond. Zooplankton Diaphanosoma, some Cladocera and Ostracoda - is sparely developed and the bottom fauna is also quite insufficient for the carp. As links between the Rotatoria and Protozoa and the carp the fry of Tilapia and Lebistes fill a niche of great importance from the point of view of production of carp. Under different circumstances Lebistes must be seen as a severe competitor for food of the carp. Here too it is eating Crustaceae and even an occasional Chironomida, but this slight disadvantage is quite overshadowed by the way Lebistes concentrates the food present in the form of too small organisms and thus makes it available in an indirect way for the carp. Dealing with an organism as the common carp the milieu is seen to have a decisive influence on relationships between two species of fish living together. The paucity of oxygen on the bottom renders the vast store of organic matter, accumulated on the bottom almost unavailable to most organisms, the extensive bacterial flora being the main agent responsible for its use. Filter-feeding Rotatoria and Protozoa subsist on these bacteria and thus constitute the next link in the food-chain.

Both Tilapia and Helostoma are independent from these foodchains, subsisting directly on vegetable micro-organisms and vegetable detritus. Food-chains as we see them in this pond and in the ponds at Bogor are shown in the diagrams, fig. 16 and 17.

\section{GENERAL CONCLUSIONS AND SUMMARY}

1. Studying quantitatively the guts contents of 500 carp fry (Cyprinus carpio $\mathrm{L}$.) from the moment the mouth and anus were formed until a total length of $135 \mathrm{~mm}$ was reached, it was found that:

a. As in all previous studies large differences were observed between the contents of the guts of comparable carp living together in the same pond and even between the contents of each quarter of the guts of the same fish.

b. Cyclopidae, Cladocera and Ostracoda formed the most important item, from the beginning throughout the experiment.

c. Chironomid-larvae were ingested from the first day on and remained most important.

d. Other aquatic insects and their larvae were eaten in increasing numbers as the fry grew older. 


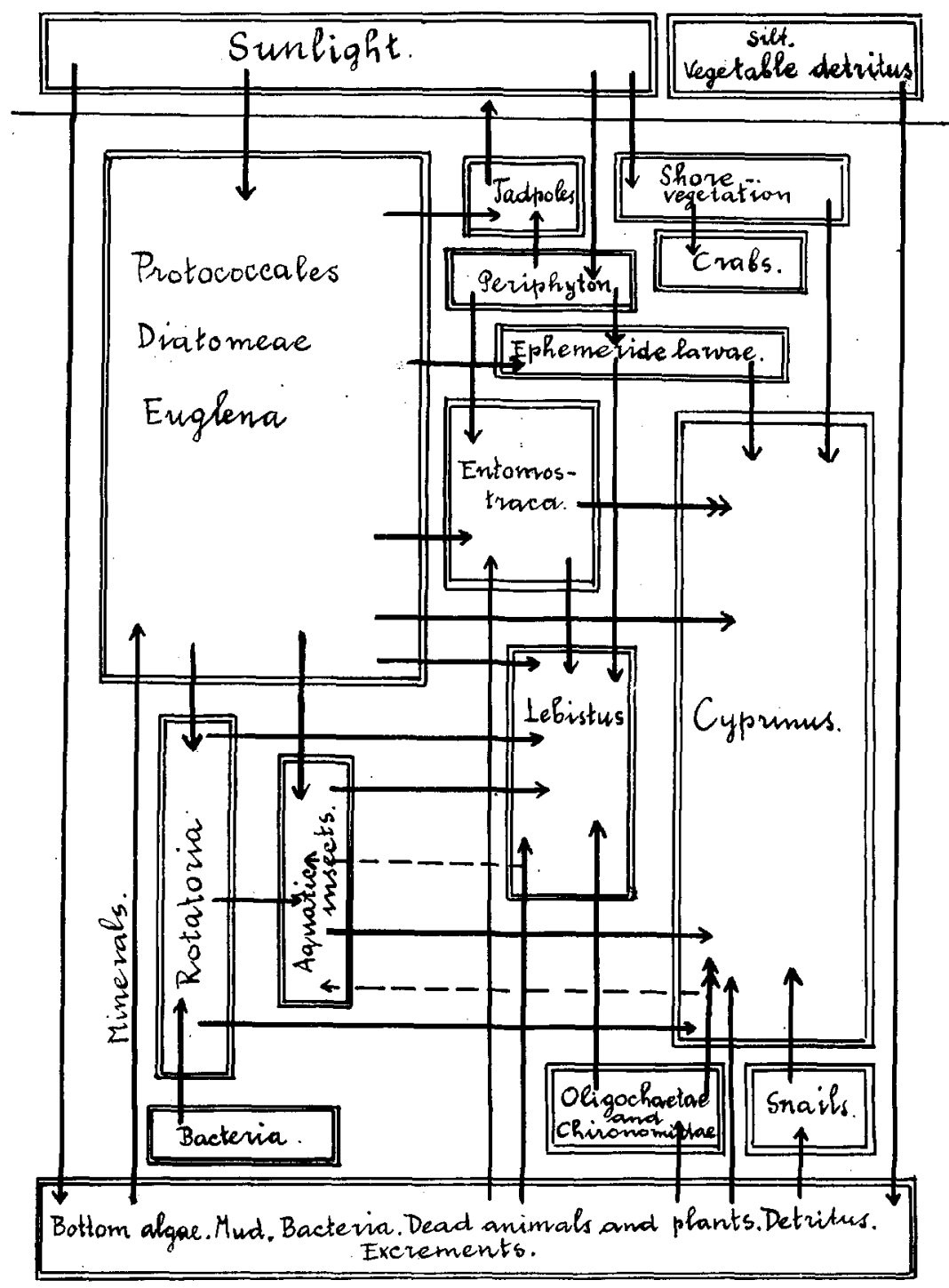

Fig. 16. Schematical representation of food-chains in a carp pond in Bogor (usual type in Indonesia). 


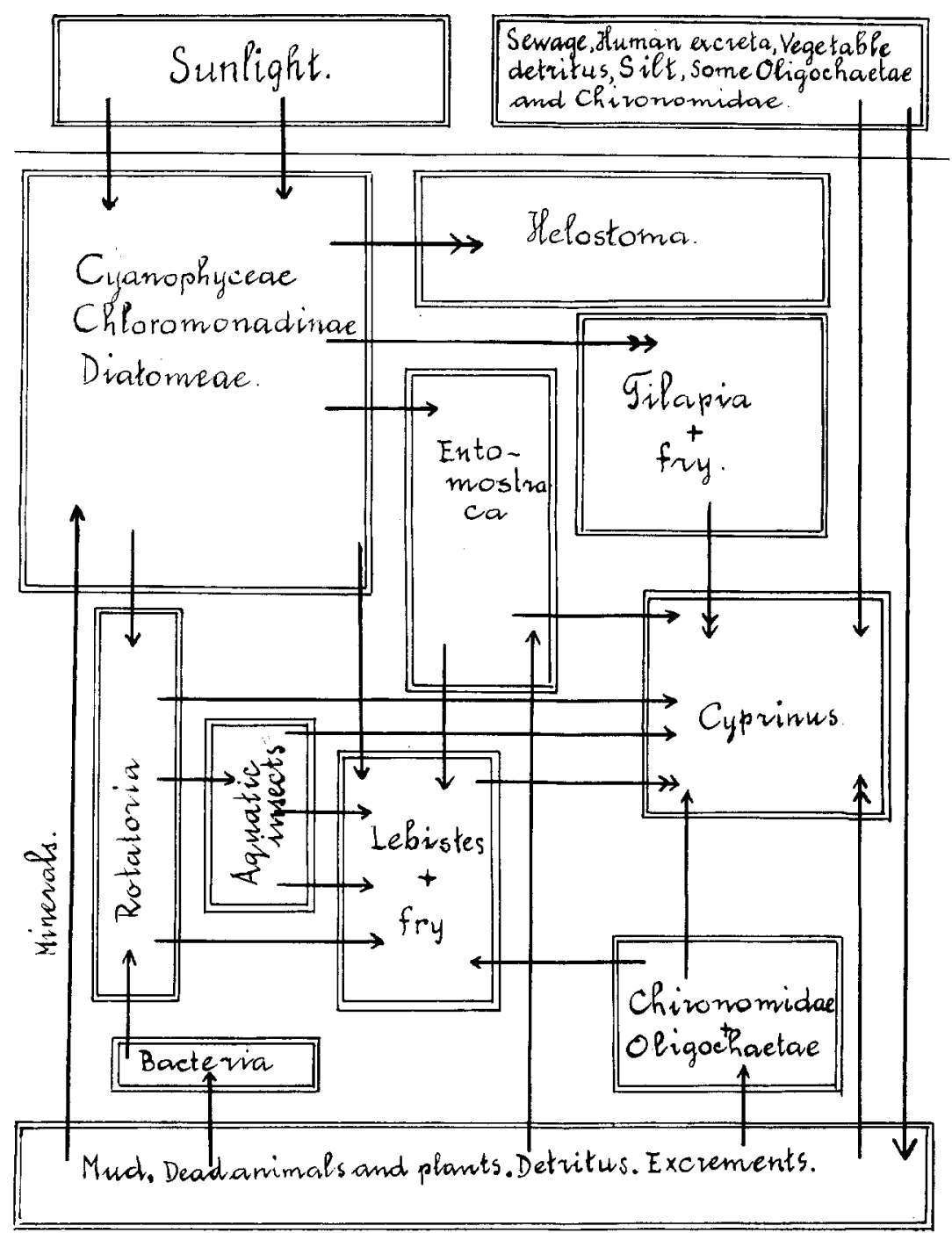

Fig. 17. Schematical representation of food-chains in the sewagepond at Bodjong Loa, Bandung. 
c. Under $40 \mathrm{~mm}$ in length the fry derives some food from Closterium, phytoplankton and Protozoa. However many phytoplankton-organisms leave the guts alive.

f. Fry longer than $40 \mathrm{~mm}$ eat small snails and also plant tissue and thread algae are ingested and partly digested by the later stages. Plant remains were readily available in the pond from green manure.

2. The length of the body and the guts showed periods of rapid increase in the beginning of each growing period, alternating with slow increase towards the end. After refilling of the pond at the beginning of each period, when growth of the carp was rapid, the ratio between length and height of the body was seen to fall, and the volume of the guts contents was seen to rise. The reverse took place towards the end of each period. This fluctuation in the quantity of food ingested was shown by all groups of natural food, except by vegetable food, of which source a continuously increasing quantity was found in the guts in most cases. In accordance with many published statements these facts might be explained in this way that vegetable food, being readily available in easily digestable form - decaying green manure is taken by the carp in increasing quantities when other sources became scarce, and that growth is slower when the carp have to depend on this source.

3. In 2 similar pond guts contents of a total of 30 carp were sampled at the end of 4 periods of 1 month. Every week biota in the pond were sampled and studied quantitatively or semi-quantitatively. Some faeces of live carp were studied and the fish weighed. Two other ponds were left unstocked each time. In this case no fodder, nor any kind of manure was given.

a. The data of the guts contents and faeces confirmed our earlier findings. Vegetable food was less important as no green manure was applied.

b. Availability of pond biota was studied and compared with the guts contents. Guts of Lebistes reticulatus, Crustaceae, aquatic insects and other biota were studied so as to obtain a picture of food-chains in stocked and unstocked ponds.

c. All organisms of importance as natural food for the carp proved to be readily available. The large supply of Diatomeae, Protococcales and Euglena was not touched by the carp. Among the Desmidiaceae the large Closterium is ingested.

d. Comparing the diet of Lebistes with that of the common carp it was found that in these ponds the diets are nearly the same when supply is plentiful, however, when Crustaceae and Chironomidae are scarce Lebistes turns to Cyanophyceae, Ro- 
tatoria and Nauplii and the carp rather to detritus, small snails and benthic algae.

c. As in all investigations concerning the development of pond biota large differences between different organisms were encountered under comparable conditions. In the first weeks usually phytoplankton grows rapidly followed by Rotatoria and Crustaceae. Melosira and other Diatoms become abundant towards the middle of the period. All plankton declines in number towards the end. Benthic organisms also show a maximal development during the second and third week. The influence of the carp on the other biota was found to be an encouragement of phytoplankton and a reduction in the numbers of benthic forms.

A theory - discussed in greater detail by the second author elsewhere - is mentioned which regards the incorporation of minerals available in the water filling the pond, as the principal limiting factor for development of pond biota. A rough quantitative comparison of the numbers of Crustaceae and Chironomidae in the guts and in the pond gave an indication that relatively more Chironomidae had been eaten in this case.

4. The guts of 53 carp from 2 ponds near Sukabumi and of 18 carp from 4 ponds near Palembang were studied and compared with the supply of pond biota. In the case of the Sukabumi ponds the fish were sampled 6 times at regular intervals during 24 hours in order to account for eventual differences in availability of Crustaceae owing to diurnal fluctuations.

a. Comparing both Sukabumi ponds it was found that a greater supply of Crustaceae, aquatic insects and vegetable food was correlated with a greater utilization by the carp, however for Chironomidae and Oligochaetae a similar relationship was not found.

b. Comparing the Palembang ponds it was found that large supplies of plant tissue and thread algae were not utilized to a marked extent.

Crustaceae from the open water and among the shore vegetation and insects larvae and worms from the bottom were ingested in accordance with local availability.

5. A sewage pond at Bodjong Loa, where common carp is cultivated in combination with Helostoma and Tilapia, was investigated.

Oxygen contents of the water at the surface fluctuated from heavy super-saturation during the day to absence at night. The bottom - covered with a thick layer of mud and vegetable detritus of allochtonous origin - was devoid of oxygen, but for a short period at noon. 
Aquatic vegetation consisted of a large bacterial flora, a heavy bloom of Euglena and small filamentous Cyanophyceae. Zooplankton was scarce. Only at some shallow spots some Chironomidae and Oligochaetae were found on the bottom, Rotatoria - feeding on the dense bacterial flora - were abundant.

In the diet of 115 common carp Crustaceae, Chironomidae and Oligochaetae were far less important than in other ponds studied owing to the limited availability of these animals. However small fry of Tilapia and Lebistes was most frequently eaten by the carp and formed its major diet here.

In this extreme environment Lebistes reticulatus, feeding on Rotatoria and phytoplankton - a kind of food too small for the common carp - here does not act as a competitor for food as is the case in all other ponds studied, but in as important chain in the food-cycle of the carp.

6. As a general conclusion derived from the study of all ponds it might be stated that the common carp in Indonesian ponds proved to be an opportunistic, polyphagous feeder. Its diet is mainly dictated by local availability of natural food. Preferring Crustaceae from the open water and organisms among the shore vegetation and benthic organisms such as midge larvae and worms, it will turn to vegetable food and even show piscivorous habits when forced by absence of other food. Concerning the question of preference for Crustaceae or Chironomidae no conclusive answer can be given. The Bogor- and Sukabumi experiments indicate that, when Crustaceae are so abundant that without much effort the carp can ingest large quantities, not much other kinds of natural food will be eaten.

Essentially we can support WUNDER's view for our ponds, that organisms from the open water are of equal importance as a source of food for the common carp as benthic organisms. Notably in the tropics the food cycle: phytoplankton - zooplankton fish proceeds at a rapid rate. When feeding on a swarm of Crustaceae the common carp will be able to ingest a good deal of food by simple straining and thus fill its guts in an easier way than eating benthic organisms from the mud.

7. Food chains as found in the carp ponds at Bogor and in the sewage pond at Bodjong Loa were depicted in two schemes. 


\section{REFERENCES}

Alikunhi, K. H. - 1952 - On the food of young carp fry; $\mathcal{F}$. Zool. Soc. India 3/4: 77 .

Bondy, A. \& A. SPANDorf - 1953 - The action of the digestive enzymes of the carp; Bamidgeh 5: 144.

BONDY, A. \& A. SPANDORF - 1954 - The action of the digestive enzymes of the carp. Brit. F. Nutrit. 8: 240.

Buschieiel, A. L. - 1938 - Stoffwechsal in tropischen Teichen fischereibiologisch betrachtet; Arch. Hydr. Suppl. Bd. 16 (Trop. Binnengew. 8): 156 .

CAHN, A. R. - 1929 - The effect of carp on a small lake: the carp as a dominant; Ecology 10: 271 .

ContaG, E. - 1920 - Merkwürdige Karpfennährung; Fish. Z. 33: 2.

DobBen, W. vaN - 1937 - Über den Kiefermechanismus der Knochenfischen; Arch. néerl. Zool. 2: 1.

HusteDT, F. - 1939 - Systematische und ökologische Untersuchungen über die Diatomeen-Flora von Java, Bali und Sumatra II. Arch. Hydr. Suppl. Bd. 16 (Trop. Binnengew. 9): 274.

HyNEs, H. B. N. - 1950 - The food of the sticklebacks (Gasterosteus aculeatus and Pygosteus pungitis) with a review of methods used in studies of the food of fishes; F. Anim. Ecol. 19:36.

JanCARIK, A. - 1956 - Über die Verdauung des Karpfens. Arch. Tierernährung. 6: 129.

Karsinkin, G. S. - 1935 - Zur Physiologie der Fischernährung als eines der Momente in der Erforschung der Produktivität der Binnengewässer; Verh. Int. Ver. Limn. 7: 398.

KLust, G. - 1935 - Tubifex als Nahrung des Karpfens; Z. Fischerei. 35: 398.

KLUST, G. - 1940 - Úber Entwicklung, Bau und Funktion des Darmes beim Karpfen: Int. Rev. Hydr. 39: 498-40: 88.

KomarovsKY, B. - 1952 - A comparative examination of the relationships between the limiting elements and the development of phytoplankton in several types of artificial ponds: Bamidgeh. 4: 138.

Kostomarov, B. \& S. Hrabé - 1942 - Der Kannibalismus bei der Karpfenbrut; Arch. Hydr. 40: 265.

Langhans, V. \& A. Pollack - 1928 - Untersuchungen über die Ernährung des Karpfens und der Schleie; Nachr. Bl. Fisch. Hirschberg. 1: 1.

Maltzan, M. von - 1935 - Zur Ernährungsbiologie und-physiologie des Karpfens; Zool. F. Abt. Allg. Zool. 55: 151

MANN, H. - 1935 - Untersuchungen über die Verdauung und Ausnutzung der Stickstoffsubstanz einiger Nährtiere durch verschiedene Fische; Z. Fisch. 33: 231.

Mitra, G. N. \& P. Mohapatra - 1956 - On the role of zooplankton in the nutrition of carp fry; Ind. Fish. 3: 299.

Moen, T. - 1953 - Food habits of the carp in North-West Iowa lakes; Proc. Iowa Acad. Soc. 60: 665.

PILlay, T. V. R. - 1952 - A critique of the methods of study of food of fishes; F. Zool. Soc. India. 4: 185.

SADLER, W. O. - 1934 - Biology of the midge Chironomus tentans Fabr. and methods for its propagation; Cornell Univ. Agr. Exp. Stat. Mem. 173.

SARBAHI, D. S. - 1951 - Studies on the digestive tracts and the digestive enzymes of the goldfish, Carassius auratus $L$. and the largemouth black bass, Micropterus salmoides (Lac.), Biol. Bull. 100: 244.

SCHÄ PERCLAUS, W. Lehrbuch der Teichwirtschaft. Berlin 1953. 
SchlottKe, E. - 1940 - Die Verdauungsfermente im Karpfendarm und ihre Änderungen während des Sommers; Z. Fisch. 33: 313.

SeILer, R, - 1938 - Die Fütterung des Karpfens beurteilt nach Aquariumversuchen; Int. Rev. Hydr. 36: 1.

SMITH, E. V. \& H. S. SwINGLe, - 1939 - Effect of organic and inorganic fertilizers on plankton production and blue-gill carrying caprcity of ponds; Trans. Acid. Fish. Soc. 69: 257.

SNIEszko, S. F. - 1957 - Use of antibiotics in the diet of Salmonid Fishes; Prog. Fish Cult. 19: 81 .

Swingle, H. S. - 1947 - Experiments on pond fertilization; Agr. Exp. Stat. Alabama Pol. Inst. 264.

TAL, S. - 1956 - A criticism of the methods of calculating of carp feeding; Bamidgeh. 8: 44.

TANG, Y.A. - 1954 - Effect of soil fertilization and water fertilization on the production of plankton, bottom organisms and goldfish in ponds; Fish. Rep. Taiwan Fish. Res. Inst. 2.

Tryson, C. A. - 1954 - The effect of carp enclosures on growth of submerged aquatic vegetation in Pymatuming Lake, Pennsylvania; F. Wildlife Manag. 18: 251.

VAAS, K. F. \& M. SACHLAN - 1955 - Limnological studies on diurnal fluctuations in shallow ponds in Indonesia; Proc. Int. Ass. Limn. 12: 309.

VAAS, K. F. \& M. SACHLAN - Cultivation of common carp in running water in West Java; Proc.I.P.F.C. 6th Meeting Tokyo 1955 (in the press).

VAAS-VAN OVEN, A. - On the theory of fishproduction in ponds; Int. Inland Fish. Training Centre Bogor (1955). (to be published by F.A.O.).

VAAS-VAN OVEN, A. - Experiments on different stocking rates of the common carp (Cyprinus carpio L.) in nursing ponds; Proc. I.P.F.C. 7th Meeting Bandung 1957 (in the press).

Vonk, H. J. - 1941 - Die Verdauung bei den niederen Vertebraten; $A d v$. in Enzym. 1: 372.

WirszuBSKY, A, - 1948 - On the food of carps in Israeli fish ponds; Hassadeh. 28.

WIRSZUBSKY, 1953 - Natural food in experimental fish ponds and its influence upon fish breeding; Bamidgeh. 5: 72.

WirSZUBSKY, A. \& M. ELCHUNES - 1952 - A preliminary report of the breeding of Chironomids in concrete ponds; Bamidgeh. 4: 15.

WUNDER, W. - 1927 - Sinnesphysiologische Untersuchungen über die Nahrungsaufnahme bei verschiedenen Knochenfischen; $Z$. vergl. Phys. 6: 67.

W UNDER, W. 1932 - Wie fangen planktonfressende Fische ihre Nahrungstiere; Z. vergl. Phys. 17: 304.

WUNDER, W. 1949 - Fortschrittliche Karpfenteichwirtschaft. Stuttgart.

Yashow, A. - 1954 - The value of natural food in fish breeding; Bamidgeh. 6: 103. 